Florida International University FIU Digital Commons

\title{
Development of a Lightweight Hurricane-Resistant Roof System
}

Ehssan Amir Sayyafi

Florida International University, eamir002@fiu.edu

DOI: $10.25148 /$ etd.FIDC001970

Follow this and additional works at: https://digitalcommons.fiu.edu/etd

Part of the Civil Engineering Commons

\section{Recommended Citation}

Amir Sayyafi, Ehssan, "Development of a Lightweight Hurricane-Resistant Roof System" (2017). FIU Electronic Theses and Dissertations. 3364.

https://digitalcommons.fiu.edu/etd/3364 


\section{FLORIDA INTERNATIONAL UNIVERSITY}

Miami, Florida

\section{DEVELOPMENT OF A LIGHTWEIGHT HURRICANE-RESISTANT ROOF SYSTEM}

A dissertation submitted in partial fulfillment of the

requirements for the degree of

DOCTOR OF PHILOSOPHY

in

CIVIL ENGINEERING

by

Ehssan Amir Sayyafi

2017 
To: Interim Dean Ranu Jung

College of Engineering and Computing

This dissertation, written by Ehssan Amir Sayyafi, and entitled Development of a Lightweight Hurricane-Resistant Roof System, having been approved in respect to style and intellectual content, is referred to you for judgment.

We have read this dissertation and recommend that it be approved.

\begin{tabular}{rr}
\hline Peter Irwin \\
\hline Irtishad Ahmad \\
\hline Ioannis Zisis \\
\hline David Garber \\
\hline Amir Mirmiran \\
\hline Arindam Gan Chowdhury, Major Professor
\end{tabular}

Date of Defense: March 30, 2017

The dissertation of Ehssan Amir Sayyafi is approved.

Interim Dean Ranu Jung College of Engineering and Computing

Andrés G. Gil

Vice President for Research and Economic Development and Dean of the University Graduate School

Florida International University, 2017 
(C) Copyright 2017 by Ehssan Amir Sayyafi

All rights reserved. 


\section{DEDICATION}

I dedicate this dissertation to my beloved parents, Ghasem and Monire, and my lovely wife and son, Mahboobe and Arman, for their unconditional love, their endless support and encouragement. 


\section{ACKNOWLEDGMENTS}

First and foremost, I would like to strongly thank my advisor, Dr. Arindam Gan Chowdhury for his supervision, guidance, financial support, patience, and investing time in me over the years. It was my honor to work with such well-respected advisor in the field of wind engineering.

I would also like to express my deepest gratitude to Dr. Amir Mirmiran for his enthusiastic endless scientific support, insightful guidance and patience throughout the course of this research, which made him a backbone of this dissertation. Working with him has been a constant learning experience for me, and undoubtedly this study would not have been possible without him.

Thanks to Dr. David Garber, for going over edits and reading through my dissertation chapters.

I am also grateful to my committee members, Dr. Peter Irwin, Dr. Ioanis Zisis, Dr. Irtishad Ahmad, for serving on my committee, and for their valuable comments, suggestions, and interest in my research.

Last but not the least; I would like to thank my parents and my wife (Ghasem, Monire and Mahboobe) for their kindness, support and patience during my hard times. Thanks to my beautiful wife for the loveliest gift she ever gave us, our lovely baby boy, Arman. 
ABSTRACT OF THE DISSERTATION

DEVELOPMENT OF A LIGHTWEIGHT HURRICANE-RESISTANT ROOF

SYSTEM

by

Ehssan Amir Sayyafi

Florida International University, 2017

Miami, Florida

\section{Professor Arindam Gan Chowdhury, Major Professor}

Roofs are the most vulnerable part of the building envelope that often get damaged when subjected to hurricane winds. Damage to the roofs has a devastating impact on the entire structure, including interior losses and service interruptions. This study aimed at the development of a novel light-weight composite flat roof system for industrial, commercial and multi-story residential buildings to withstand Category 5 hurricane wind effects based on the Florida Building Code requirements for hurricane-prone regions, the strictest wind design code in the United States.

The proposed roof system is designed as a combination of two advanced materials: ultra-high performance concrete (UHPC), reinforced with high strength steel (HSS). The novel combination of these two materials in a specially designed cross section led to a lightweight low-profile ultra-thin-walled composite roof deck, with only 17 pounds per square foot self-weight, 4-inch overall depth and only $3 / 4$-inch thick flanges and webs, with no shear reinforcement or stirrup. Two groups of specimens, single-cell and multi-cell, were fabricated and tested in four-point flexure to determine the ultimate bending capacity and ductility of the system. Each group of specimens included two short-span (9 ft.) 
samples (due to the laboratory constraints) -- one specimen subjected to positive bending and the other one subjected to negative bending, representing the critical loading conditions including the effects of wind pressures. All specimens exhibited pure flexural failure in a ductile behavior and with no sign of shear failure. Finite element models of laboratory specimens were also developed and calibrated based on experimental data in order to project the performance of the system for larger and more realistic spans. The experimental work and the finite element analyses showed that the proposed roof system with its given section has adequate flexural and shear strength, and also meets serviceability requirements for a 20 -foot long span. Moreover, connections for the roof system were proposed, including panel-to-panel connections and roof-to-wall connections.

In addition to safety, the other advantages of the proposed roof system in comparison to the equivalent reinforced concrete roofs include a three-fold reduction in self-weight, a three-fold reduction in overall profile height, and a five-fold reduction of steel reinforcement. Together, these advantages may lead to an increased span length beyond what is typically feasible for the conventional reinforced concrete slabs. All these features translate the proposed deck to a sustainable roof system.

Keywords: Ultra-High Performance Concrete (UHPC), Concrete, Deck, High Strength Steel (HSS), Roof, Wind, Hurricane, Thin-wall, Lightweight, Sustainability, Ultra-High Performance Fiber Reinforced Concrete (UHPFRC) 


\section{TABLE OF CONTENTS}

CHAPTER

PAGE

CHAPTER 1: INTRODUCTION

1.1 Introduction

1.2 Objective

1.3 Methodology

1.4 Organization of Dissertation

CHAPTER $2 \cdot$ SYSTEM DESIGN

2.1 Design Requirements

2.1.1 Ultimate Limit States Requirements

2.1.2 Serviceability Limit State Requirements

2.2 Design Loads

2.3 Materials of Construction

2.3.1 Slim Design Using UHPC and HSS

2.4 System Design

2.4.1 Section Shape

2.4.2 Roof Geometry

2.4.3 Slab Action

2.4.4 Section Properties

CHAPTER 3: EXPERIMENTAL APPROACH TO ASSESS THE ULTIMATE LIMIT STATES OF THE NEW ROOF SYSTEM

3.1 Introduction

3.2 Flexural Strength

3.2.1 Experimental Work

3.2.2 Test Matrix

3.2.3 Specimens Fabrication

3. 2.4 Test Setup and Instrum

3.2 .4 Test Setup and Instrumentation

3.2.5 Test Results and Discussions

3.2.6 Panel Action

3.2.7 Flexural Strength

3.3 Shear Strength

3.3.1 Experimental Work

3.3.2 Test Setup and Instrumentation

3.3.3 Test Results and Discussion

CHAPTER 4: FINITE ELEMENT MODELING VALIDATION AND ASSESSMENT

OF THE SERVICE LIMIT STATE OF THE NEW ROOF SYSTEM 61

4.1 Introduction $\quad 61$

4.2 Finite Element Modeling Verification $\quad 61$

$\begin{array}{ll}\text { 4.2.1 Boundary Conditions } & 62\end{array}$

$\begin{array}{ll}\text { 4.2.2 Element Types } & 62\end{array}$

4.2.3 Material Property $\quad 63$

4.2.4 Finite Element Results 66

4.3 Finite Element Modeling of the Full-length Roof Panel 72

4.3.1 Finite Element Results 
CHAPTER 5: DEVELOPMENT OF CONNECTIONS 77

$\begin{array}{ll}5.1 \text { Introduction } & 77\end{array}$

5.2 Panel to Panel Connection $\quad 77$

5.2.2 Experimental Work $\quad 83$

5.2.3 Test Setup $\quad 84$

5.2.4 Test Results

5.3 Roof-to-Wall Connection 88

CHAPTER 6: SYSTEM ADVANTAGES 94

6.1 Introduction $\quad 94$

6.2 Structural Efficiency 95

6.3 Material Cost 96

6.4 Financial Benefits $\quad 97$

6.5 Sustainability 99

6.6 Energy Efficiency $\quad 100$

$\begin{array}{ll}6.7 \text { Safety } & 100\end{array}$

6.8 Additional Features 101

CHAPTER 7: CONCLUSIONS 102

$\begin{array}{ll}7.1 \text { Summary } & 102\end{array}$

$\begin{array}{ll}7.2 \text { Conclusions } & 103\end{array}$

$\begin{array}{ll}7.3 \text { Future Research } & 106\end{array}$

$\begin{array}{ll}\text { REFERENCES } & 107\end{array}$

$\begin{array}{ll}\text { VITA } & 111\end{array}$ 


\section{LIST OF TABLES}

TABLE

PAGE

Table 2-1 Allowable Deflection Limits for Roof Structures Permitted by the

Florida Building Code (FBC) 2010

Table 2-2 Wind Load Estimation Parameters for Key West, Florida According to

ASCE 7-10 for Exposure C.

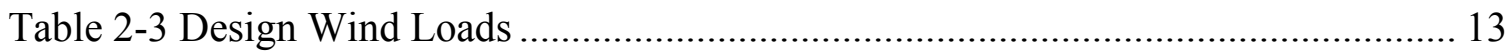

Table 2-4 Design Loads Induced by Load Combinations ........................................... 14

Table 2-5 UHPC Proportion of Constituent of Materials ........................................... 18

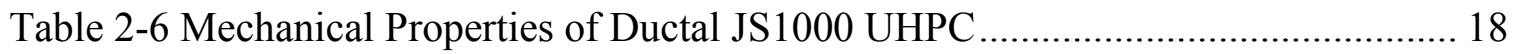

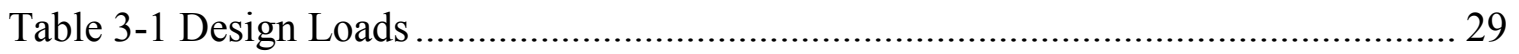

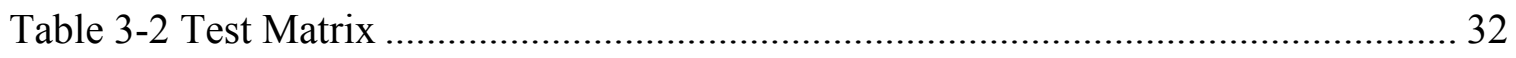

Table 3-3 Material Properties of ChrōmX 9100 Reinforcing Bar .................................. 32

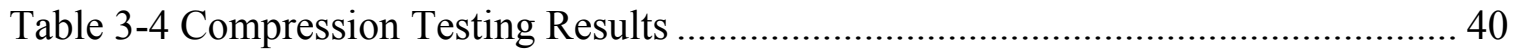

Table 3-5 Summary of Flexural Test Results ........................................................... 46

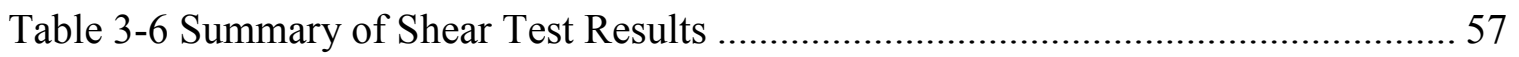

Table 4-1 UHPC plasticity parameters defined in FE models used for all models .......... 66

Table 4-2 Summary of Finite Element Analyses and Experimental Results ................... 72

Table 4-3 Allowable deflections for roof supporting nonplaster ceiling, and respective

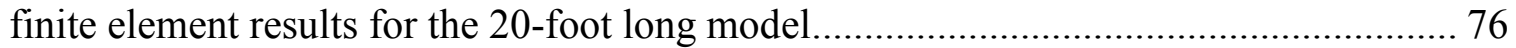

Table 5-1 The Geometric Details of Flange Connection Specimens and Summary

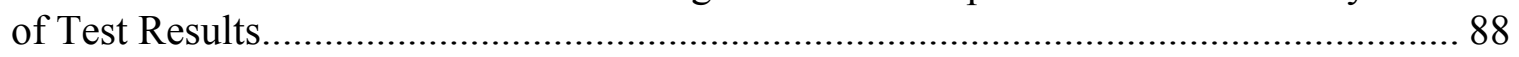

Table 6-1 The New Roof System Against Lite-Deck Deck System.............................. 96

Table 6-2 Material Costs for the Proposed Roof System and Conventional Concrete

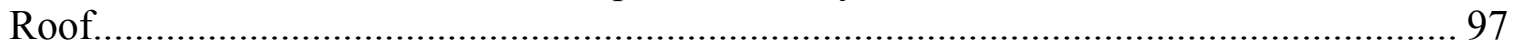

Table 6-3 R-Value of the Proposed Roof System........................................................ 100 


\section{LIST OF FIGURES}

FIGURE

PAGE

Figure 2-1 The case study building dimensions and wind configuration ....................... 11

Figure 2-2 Internal and external pressure coefficients on the flat roof of the building .... 12

Figure 2-3 Stress-Strain responses of high strength steel (HSS), ChromaX 9100, and steel grade 60

Figure 2-4 The cross-sectional shapes initially considered for the development of the new roof system

Figure 2-5 The initial cross-sectional shape considered for the development of the new roof system.

Figure 2-6 Isometric views of the proposed roofing system: (a) Top view; (b) Bottom view

Figure 2-7 Structural action of the proposed roof system........................................... 25

Figure 2-8 Geometric details of the engineered box-cell section ................................ 27

Figure 3-1 Schematic of Single-cell Specimen: (a) Plane view; (b) Side view; (c) Crosssection

Figure 3-2 Schematics of Multi-cell Specimen: (a) Plan view; (b) Side view; (c) Crosssection

Figure 3-3 Formwork made of Styrofoam for single-cell specimens ............................. 33

Figure 3-4 Formwork made of Styrofoam for Multi-cell panel specimens ...................... 33

Figure 3-5 Single-cell specimens preparation........................................................ 36

Figure 3-6 Multi-cell specimens preparation.......................................................... 37

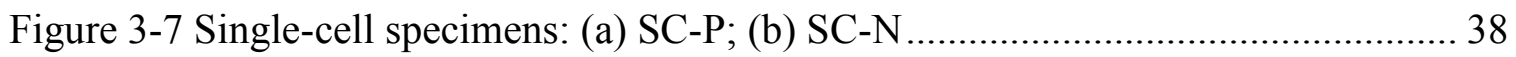

Figure 3-8 Multi-cell panel specimens: (a) MC-P; (b) MC-N ........................................ 38

Figure 3-9 Lateral shrinkage cracks on the top flange of SC-P specimen due to the high $\mathrm{w} / \mathrm{c}$ ratio in the UHPC mix. 
Figure 3-10 Minute unreacted clumps of Portland cement in the hardened UHPC matrix of SC-P specimen, due to the lack of experienced construction personnel and selection of improper mixing equipment

Figure 3-11 Flexure test setup: (a) Specimen SC-P; (b) Specimen SC-N;

(c and d) Specimen MC-P; (e and f) Specimen MC-N.

Figure 3-12 Test setup and instrumentation details of Single-cell specimens: (a) Side view; (b) Specimen SC-P; (c) Specimen SC-N

Figure 3-13 Test setup and instrumentation details of Multi-cell specimens: (a) Side view; (b) Specimen MC-P; (c) Specimen MC-N.

Figure 3-14 Loading system utilized for testing of Multi-cell specimens 45

Figure 3-15 Flexural test modes of failure; (a) SC-P; (b) SC-N; (c) MC-P; (d) MC-N ... 47

Figure 3-16 Load-Deflection responses at mid- and quarter-span of Single-cell

Specimens

Figure 3-17 Load-Deflection responses at mid- and quarter-span of Multi-cell Specimens

Figure 3-18 Load-Strain responses of HSS reinforcement of Single-cell specimens

Figure 3-19 Load-Strain responses of HSS reinforcement of Multi-cell specimens 50

Figure 3-20 Load-Tensile strain responses of UHPC in Single-cell specimens .............. 51

Figure 3-21 Moment-Deflection responses at mid-span of Multi-cell specimens............ 53

Figure 3-22 Geometric details of shear specimen (SC-S) ....................................... 54

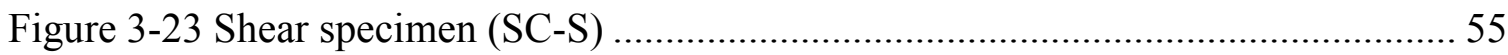

Figure 3-24 Test setup and instrumentation with shear specimen SC-S ....................... 56

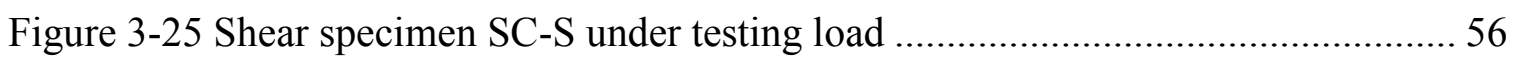

Figure 3-26 Shear test mode of failure and crack patterns, specimen SC-S ................... 58

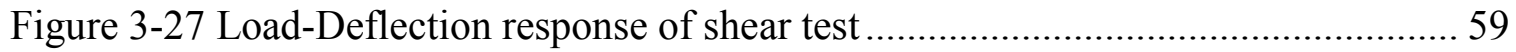

Figure 4-1 Finite Element model of laboratory specimens; (a) SC-P; (b) SC-N;

(c) MC-P; (d) MC-N 
Figure 4-2 Mesh density of Finite Element models; (a) SC-P; (b) SC-N; (c) MC-P; (d) $\mathrm{MC}-\mathrm{N}$......

Figure 4-3 Uniaxial stress-strain responses of HSS ChromaxX 9100 (Grade 100) and equivalent responses used for FE modeling.

Figure 4-4 Deflected shape and failure mode of specimen SC-P: (a) Stress distribution, top view: (b) Stress distribution, side view (c) Failure mode in experimental test

Figure 4-5 Deflected shape and failure mode of specimen SC-N: (a) Stress distribution,

top view: (b) Stress distribution, side view (c) Failure mode in experimental test ......... 68

Figure 4-6 Stress distribution on the deflected shape and failure mode of specimen MC-P.

Figure 4-7 Stress distribution on the deflected shape and failure mode of specimen MC-N.

Figure 4-8 Load-Deflection response of SC-P at mid-span...................................... 70

Figure 4-9 Load-Deflection response of SC-N at mid-span ..................................... 70

Figure 4-10 Load-Deflection response of MC-P at mid-span of middle unit (C2) ......... 71

Figure 4-11 Load-Deflection response of MC-N at mid-span of middle unit (C2) ......... 71

Figure 4-12 Finite Element model of 20-foot multi-cell roof panel: (a) Side view; (b) Cross section; (c) Top view; (d) Bottom view ............................................................. 74

Figure 4-13 Deflection states at loading conditions .............................................. 75

Figure 4-14 Load-Deflection response of proposed roof panel for $20 \mathrm{ft}$. span with nonplaster ceiling, resulted from finite element models.

Figure 5-1 Panel-to-Panel connection and its components: (a) Components of Panel-to-

Panel connection; (b) Flange connection; (c) Rib connection 79

Figure 5-2 Details of flange connection as the Panel-to-Panel connection compartment; (a) Geometric details; (b) Geometric details of Group1 connection specimens; (c) Geometric details of Group 2 specimens 81

Figure 5-3 Group 1 connection specimen preparation, FC-P and FC-N specimens......... 82

Figure 5-4 Simplified flange connection samples: (a) FC-P Specimen; (b) FC-N specimen; (c) SOLID-1 specimen; (d) SOLID-2 specimen 82

Figure 5-5 Test setup for flange connection 84 
Figure 5-6 FC-P specimen under three-point positive bending test

Figure 5-7 FC-N specimen under three-point negative bending test. 85

Figure 5-8 Group 2 specimen under three-point bending test: (a) SOLID-1 Specimen; (b) SOLID-2 Specimen .... 86

Figure 5-9 Failure mode of flange connection samples: (a) FC-P specimen; (b) FC-N specimen; (c) SOLID-1 specimen; (d) SOLID-2 specimen.

Figure 5-10 Moment-Deflection response of flange connections (panel-to-panel specimen connections) 88

Figure 5-11 Roof-to-wall connection details to: (a) Masonry structure; (b) Reinforced concrete structure; (c) Steel structure

Figure 6-1 Cross section of the new roof system compared to Lite-Deck deck system ... 96

Figure 6-2 The new roof system improvement compared to Lite-Deck......................... 96 


\section{CHAPTER 1}

\section{INTRODUCTION}

\subsection{Introduction}

Hurricanes are ranked as the second costliest natural disaster in the world, representing over 30\% of total financial losses from such events (Munich Re 2014). They are the costliest disasters in the United states, with $\$ 41$ billion insured catastrophic losses during 1986-1993 (Simiu and Scanlan, 1996), that may double every 10 years (Pielke et al. 2008). In the U.S. alone, $67 \%$ of severe weather and climate disaster events have been hurricane-related (NOAA 2016), for the 1980-2016 period. In the last two decades, the densely populated eastern seaboard of the U.S. -- with more than $50 \%$ of the U.S. population (Crossett et al. 2013) -- has emerged as one of the most vulnerable locations in the country to incoming hurricanes and windstorms, hence, commanding very high property insurance. Assessment of the historical hurricanes indicates that hurricane wind is the major cause of property loss (Ayscue, Jon K. 1996; Knabb et al. 2005), with major damage to the building envelope (Sparks et al. 1994), especially roof, which is the first line of defense against extreme weather events. Storm-related damage to the roof as well as interior and content damages from wind-driven rain account for about $80 \%$ of the total buildings losses. These hurricane-related indemnities lead to significant financial liabilities to the homeowners and insurance companies. During Hurricane Andrew (1992) - the fifthcostliest natural disaster and third-most expensive hurricane in the United States (NOAA 2016a) -- the extensive financial damage sent insurance rates skyrocketing and major insurers in the State of Florida into bankruptcy. Florida is the most vulnerable U.S. state to 
hurricanes with more than $40 \%$ landfall possibility (NOAA 2016b). Therefore, the hurricane resilience of building envelope has the potential to minimize high wind damages, and result in improvement of post- disaster conditions.

In a typical windstorm, roofs are subjected to high wind uplift pressure, especially around edges and corners. High wind suction exerted on flat roofs is caused by flow separation taking place at the edges and cornering vortices when wind acts at 45 -degree wind direction (Banks et al. 2000; Wu et al. 2001; Kind and Wardlaw, 1979). Such wind uplift pressure causes devastating damages to the conventional roofs and often leads to water intrusion that causes significant interior and contents damage, making the building practically uninhabitable until fully repaired. The vulnerability of conventional roofs stems from the simple fact that they consist of multiple components and layers -- such as metal roof decks, lightweight concrete, and various forms of insulations -- joined together by numerous connections (e.g., fasteners, adhesives, and sealants). Quite often, it is not the colossal failure of the structural system at the design wind speed, but rather the failure of roof elements (e.g., roof covering or cladding) at lower wind speeds that lead to water intrusion and subsequent losses.

Malfunctioning of a weak link may lead to the total system failure. Poor performance of a weak link leads to a local destruction and may cause opening in the roof and causing increased internal and uplift pressure, as well as the failed elements become wind-borne debris. Roof failure, partially or entirely, causes extensive water intrusion and subsequent interior loss, which results in costly repairs. Moreover, the weak roof components become wind-borne debris and source of damage to the surrounding buildings. These damages caused by severe storms like hurricanes and tornadoes can be minimized 
by implementation of a well-designed roof system, which is the objective of the present study.

\subsection{Objective}

One possible solution to this challenge is to integrate the structural (i.e., the main wind force resisting system or MWFRS) and architectural elements (i.e., the components and cladding or $\mathrm{C} \& \mathrm{C}$ ) into a single unified or monolithic roofing system with significantly reduced number of inter-component connections. The objective of this research is to develop a monolithic hurricane-resistant composite roof system by combining the main wind force resisting system (MWFRS) and components and cladding (C\&C) to achieve the hurricane resilience of buildings during extreme weather events. Mintz et al. (2015 \& 2016) proposed one such system, primarily for residential buildings. Their proposed "Super-Tile" system mimicked the shape of aesthetically pleasing barrel-type tile roofs so prevalent in sloped gable- or hip-roof residential buildings in the South. This study offers a similarly innovative solution, however, as a wind-resistant flat roof system for industrial and commercial buildings or for multi-story residential buildings. In addition, the proposed system combines two advanced materials, i.e., ultra-high performance concrete (UHPC) and high-strength steel (HSS) in a unique structural design that optimizes the material use for wind resistance.

First developed in France in the 1990's (Keierleber et al. 2007), UHPC consists of high-strength cementitious materials, short steel fibers, ground quartz, and super plasticizer (Habel et al. 2006, and Graybeal 2007). UHPC has significantly less permeability, creep and shrinkage as compared to conventional concrete (Graybeal 2007). On the other hand, 
UHPC has significantly higher compressive strength, elastic modulus, tensile strength, durability and damage tolerance than conventional concrete (Graybeal 2005, Ahlborn et al. 2008). Most recently, UHPC was used for ultra-thin cladding at the Adrienne Arsht Center in Miami, Florida, with specific consideration for hurricane resistance of the cladding. HSS reinforcing bar is another advanced material with almost $25 \%$ higher yield strength, six times more corrosion resistance and two times slower corrosion rate than conventional steel. These exceptional properties can lead to less reinforcement, longer service life and lower life cycle costs for structural applications (Kahl 2007).

\subsection{Methodology}

This study aimed at the development of a lightweight hurricane-resistant composite roof system designed in accordance with the Florida Building Code (FBC 2010), the most stringent wind design code in the United States, for hurricane-prone regions to mitigate hurricane resilience of commercial, industrial and multi-story residential towers during high wind storms. Additional to the wind design, effort was made to effectively improve the capacity/weight ratio of the system by increasing the structural strength, while decreasing the weight, which finally translated to a high performance structural system. The objective became feasible through the combination of two advanced materials: (1) ultra-high performance concrete (UHPC); and (2) high strength steel (HSS). In order to achieve the milestone, a comprehensive development plan and procedure was established as follows:

1) Determination of the design loads and design criteria in accordance with the FBC (2010); 
2) Preliminary design by developing a structural shape - termed as box-cell that is efficient and effective in both loading conditions: positive bending and negative bending;

3) Experimental tests on the first group of short-length (9-ft) laboratory specimens, termed as single-cell (Amir-Sayyafi et al. 2016), to confirm the constructability, investigate the ultimate flexural and shear strength, and verify the design approach;

4) Experimental tests on the second group of short-length (9-ft.) laboratory specimens, termed as multi-cell roof panels, to assess the overall performance, ultimate flexural capacity, ductility, and mode of failure (Sayyafi et al. 2017);

5) Development of the Finite Element models of all testing specimens, and verification with the tests results to evaluate the overall performance and check the serviceability of a full-length span;

6) Propose of potential connections.

This dissertation describes all the items listed above.

\subsection{Organization of Dissertation}

The dissertation is structured to follow the course of the research as described in the previous section. This chapter, Chapter 1 , is an introduction to the problem and its proposed solution -- the hurricane-resistant roof system. Chapter 2 describes the design requirements in accordance with the Florida Building Code; determines the design loads, including wind load calculations; details the geometry of the proposed roof system; and 
materials of construction. Chapter 3 details the experimental program on laboratory specimens, and how the proposed roof deck successfully met the demand ultimate strength - flexure and shear - for a 20 -foot long span. All testing specimens are investigated at ultimate limit state (ULS). Test setup and test results are presented. The feasibility and constructability of the system are also discussed. Chapter 4 presents the finite element modeling and verification. The purpose of this chapter is to present the serviceability design performance of the multi-cell panel specimens through the finite element models calibrated with testing results. It demonstrates how the proposed roof system is evaluated at serviceability limit state (SLS), and shows how the system meets serviceability requirements specified by the Florida Building Code (2010) for a 20-foot long span. Chapter 5 reports on the proposed roof connections, including test results from connection specimens. Additional to the wind-resistant and structural enhancements, several significant improvements were obtained during this study, as presented in Chapter 6. The final chapter, Chapter 7, summarizes the outcomes of the research and demonstrates the novelty and scientific contributions of the present study. Future works are also documented to take advantages of the results produced by this study and move the concept forward to other structural systems for the most efficient and optimized structural elements. 


\section{CHAPTER 2}

\section{SYSTEM DESIGN}

\subsection{Design Requirements}

The new roof is designed in accordance with the provisions of the Florida Building Code (2010) using Limit State Design (LSD) approach. LSD includes two design criteria known as: (1) Ultimate Limit States (ULS); and (2) Serviceability Limit States (SLS). The roof unit was first proportioned to resist the factored loads prescribed in the general building code -- ultimate limit states. Next, the roof deflection -- due to the live load and wind load -- were compared to the deflection limits allowed by the code -- serviceability limit states.

\subsubsection{Ultimate Limit States Requirements}

Limit state design of new roof systems includes design for moment and shear under failure loads, which is known as "Strength Design". Strength design philosophy is the method based on the fact that the design loads are greater than the service loads. Design loads are service loads multiplied by factors in load combinations prescribed in building codes. Strength design for flexure requires that the design flexural strength of a member exceeds the factored moment. Design flexural strength is the nominal bending strength $\left(\mathrm{M}_{\mathrm{n}}\right)$ reduced by applying a reduction factor, $\Phi$. And, factored moment $\left(\mathrm{M}_{\mathrm{u}}\right)$ is the moment computed by using design loads. In fact, according to the strength design, the nominal strength of the roof unit performs in the region of inelastic behavior of material. Similarly, 
strength design requires the design shear strength of the roof section $\left(\Phi . V_{n}\right)$ exceed the factored shear $\left(\mathrm{V}_{\mathrm{u}}\right)$. Equations 2-1 and 2-2 describe the strength design requirements.

$$
\begin{array}{ll}
\Phi \cdot \mathrm{M}_{\mathrm{n}} \geq \mathrm{M}_{\mathrm{u}} & (\text { Equation 2-1) } \\
\Phi \cdot \mathrm{V}_{\mathrm{n}} \geq \mathrm{V}_{\mathrm{u}} & (\text { Equation 2-2) }
\end{array}
$$

where $\Phi$ is the reduction factor specified by building codes, $M_{n}$ and $V_{n}$ are the nominal bending strength and nominal shear strength, respectively, and $\mathrm{M}_{\mathrm{u}}$ and $\mathrm{V}_{\mathrm{u}}$ are the factored moment and factored shear, respectively.

In this study, the nominal moment strength $\left(\mathrm{M}_{\mathrm{n}}\right)$ and nominal shear strength $\left(\mathrm{V}_{\mathrm{n}}\right)$ are obtained by conducting tests on laboratory specimens. The factored moment $\left(\mathrm{M}_{\mathrm{u}}\right)$ and factored shear $\left(\mathrm{V}_{\mathrm{u}}\right)$ are calculated by the use of factored loads and load combinations in accordance with the Florida Building Code (2010). A $\Phi$ reduction factor of 0.9 and 0.75 are used as specified by the ACI Code (ACI 318) for flexure and shear design, respectively. Then, the reduced nominal strengths are compared with the relative factored strength. The design loads are described in details in a section later in this chapter.

\subsubsection{Serviceability Limit State Requirements}

According to the FBC (2010), in addition to the strength design, the system shall be designed for conformance with serviceability limit state (SLS). SLS requires the system to have adequate stiffness to limit deformation. SLS deflections of roof structures shall not exceed the more restrictive of deflection that permitted by Table $2-1$. The table lists the SLS limits under live load, wind load, and combination of dead load and live load. According to the table, roofs not supporting ceilings are allowed more deflection than those supporting plaster or nonplaster ceilings. Nonplaster and not supporting ceilings are 
commonly used in the case of industrial and commercial buildings; however, the most conservative of those two cases is considered in this study, i.e.: supporting the nonplaster ceiling. In this case, deflection is limited to span length divided by 240 for both live load and wind load, and span length divided by 180 under combined dead load and live load. The deflection criteria considered here can accordingly be adjusted in accordance with the intended building code for a given project.

Table 2-1 Allowable Deflection Limits for Roof Structures Permitted by the Florida Building Code (FBC) 2010

\begin{tabular}{llll}
\hline Roof & L & W & D + L \\
\hline Supporting plaster ceiling & $1 / 360$ & $1 / 360$ & $1 / 240$ \\
Supporting nonplaster ceiling* & $1 / 240$ & $1 / 240$ & $1 / 180$ \\
Not supporting ceiling & $1 / 180$ & $1 / 180$ & $1 / 120$ \\
\hline
\end{tabular}

*The case considered in this study.

Also, Florida Building Code requires roofs resist a 300-lb.-concentrated load (i.e., workers on the roof during construction or maintenance) uniformly distributed over an area of $2 \frac{1}{2}$ feet by $2 \frac{1}{2}$ feet, located where the load produces the maximum load effects on the roof.

As described in the next chapter, Chapter 3, laboratory constraints limited the specimens' length to a shorter length than the design span, therefore finite element analyses was implemented in order to estimate the SLS deflection. Chapter 4 specifically reports on serviceability evaluation in details. 


\subsection{Design Loads}

As previously mentioned, the new roof structure is designed to comply with the Florida Building code (2010). It is engineered and constructed to resist safely the nominal loads in the loading cases defined by the building code, and to be limited to the specified strength limit states and serviceability limit states for the materials of construction.

Nominal design loads are determined using the provisions of the FBC 2010 for hurricane-prone areas, e.g. Key West, Florida. The FBC 2010 follows ASCE-7 (the American Society of Civil Engineers' 'Minimum Design Loads for Buildings and Other Structures') for the determination of wind loads. Wind pressures on the main wind force resisting system (MWFRS) is determined using the Directional Procedure - Regular Approach for All Heights, the approach that is contained in Section 1609.6 of the FBC (2010). This approach follows ASCE 7-10 in certain parts with the equations and coefficients in a different framework.

Since building configuration, specially height of the building, has significant impact on the wind force calculations, as the case study, a low-rise flat roof building is considered with a $50 \mathrm{ft}$. mean roof height. It is the height in the range of the most common elevation of commercial and industrial buildings. In order to estimate the most critical wind pressures, wind should act parallel to the short building dimension of the length equal or less than the building height ( $50 \mathrm{ft}$. or less), with the long building dimension of any length -- in this study $200 \mathrm{ft}$. Fig. 2-1 depicts the building dimensions considered in this study, the case study that represents the worse wind pressures at the mean roof height of 50 feet. 


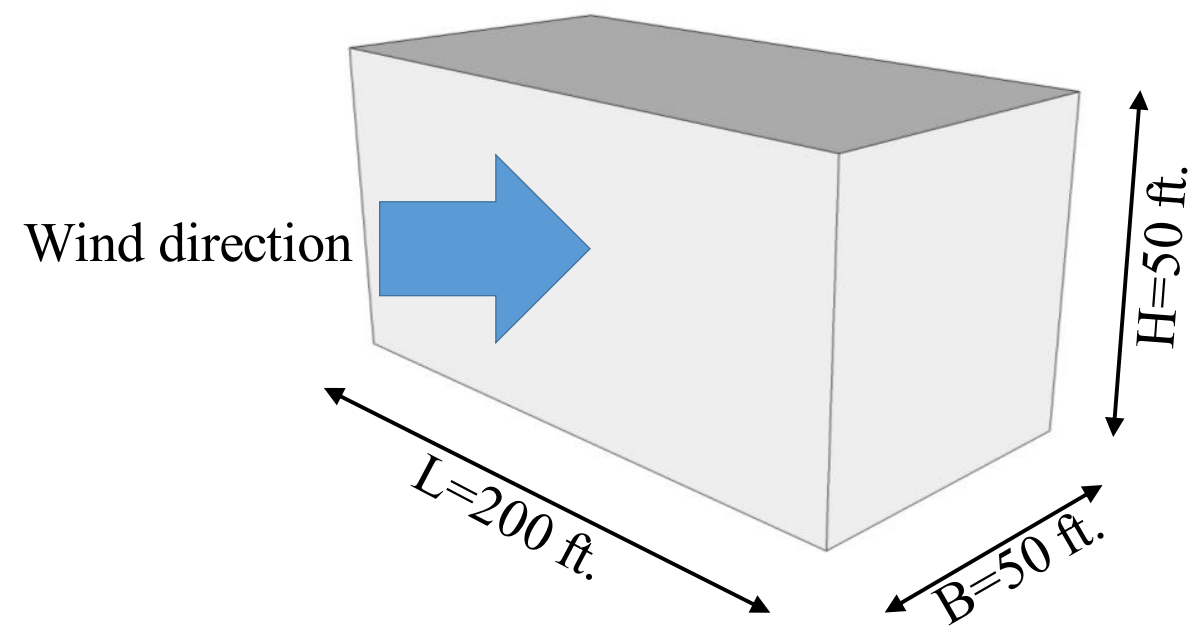

Figure 2-1 The case study building dimensions and wind configuration

The 3-second gust wind speed for a Category 3 building located in Key West, Florida is 200 miles per hour at $33 \mathrm{ft}$. above ground for Exposure C category. Table 2-2 lists the required design parameters as specified by the ASCE 7-10 to calculate the wind speed at roof level (50 ft.) of the case study building.

Table 2-2 Wind Load Estimation Parameters for Key West, Florida According to ASCE 7-10 for Exposure C

\begin{tabular}{lcccc}
\hline Description & Parameter symbol & Value & Units & Source \\
\hline Mean roof height & $\mathrm{h}$ & 50 & $\mathrm{ft}$. & Case study \\
Velocity pressure exposure & $\mathrm{K}_{\mathrm{z}}$ & 1.09 & - & Table 27.3-1 \\
coefficient & & & & \\
Topographical factor & $\mathrm{K}_{\mathrm{zt}}$ & 1.0 & - & Section 26.8.2 \\
Wind directionality factor & $\mathrm{K}_{\mathrm{d}}$ & 0.85 & - & Table 26.6-1 \\
Basic wind speed & $\mathrm{V}$ & $200^{*}$ & $\mathrm{mph}$ & Figure 26.5-1B \\
Gust-effect factor & $\mathrm{G}$ & 0.85 & - & Section 26.9-1 \\
\hline
\end{tabular}

*According to ASCE 7-10, the 3-second gust wind speed for a Category 3 building located in Key West, Florida is 200 miles per hour at $33 \mathrm{ft}$. above ground for Exposure $\mathrm{C}$ category. 


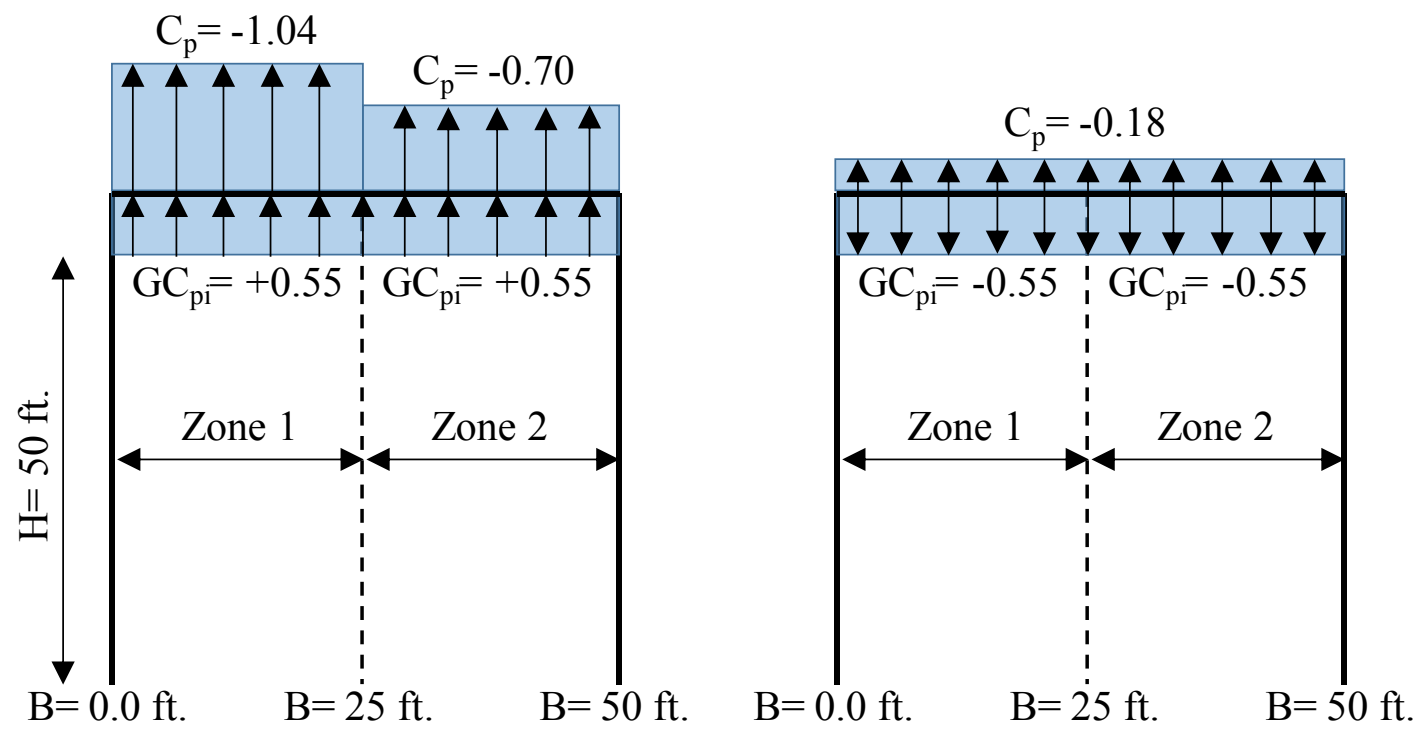

Figure 2-2 Internal and external pressure coefficients on the flat roof of the building

The new roof is designed as MWFRS, with the assumed enclosure classification of partially enclosed structure with internal pressure coefficient (GCpi) of $-/+0.55$. Two critical cases shall be considered in the determination of the most sever aerodynamic net pressures as follows (Fig. 2-2):

Zone 1: Positive internal pressure with maximum negative external pressure (upward)

Zone 1 and 2: Negative internal pressure with minimum negative external pressure (down-ward)

The maximum wind pressures are listed in Table 2-3 for both zones depicted in Figure 2-2. The design wind loads are considered in load combinations specified in Section 1605.2 of the FBC (2010), as follows:

Load combination 1: 1.2D+1.6 $\mathrm{Lr}+0.5 \mathrm{~W}$

(Equation 2-3)

Load combination 2: $1.2 \mathrm{D}+1.0 \mathrm{~W}+0.5 \mathrm{Lr}$

(Equation 2-4)

Load combination 3: $0.9 \mathrm{D}+1.0 \mathrm{~W}$

(Equation 2-5) 
Where D is dead load, $\mathrm{Lr}$ is roof live load in accordance with an applicable building code; and W is wind load, as determined earlier.

Table 2-3 Design Wind Loads*

\begin{tabular}{ccc}
\hline Zone & Maximum negative $\left(\mathbf{l b} / \mathbf{f t}^{2}\right)$ & Maximum positive $\left(\mathbf{l b} / \mathbf{f t}^{\mathbf{2}}\right)$ \\
\hline 1 & -136.05 & +37.66 \\
\hline 2 & -108.63 & +37.66
\end{tabular}

*The values are calculated by applying the following equations. $\mathrm{q}=0.00256 \cdot \mathrm{K}_{\mathrm{z}} \cdot \mathrm{K}_{\mathrm{zt}} \cdot \mathrm{K}_{\mathrm{d}} \cdot \mathrm{V}^{2}$, where $\mathrm{q}$ is the velocity pressure at roof height. Source: ASCE 710 Eq. 27.3-1. All parameters are given in Table 2-2.

$\mathrm{p}=\mathrm{q} \cdot \mathrm{G} \cdot \mathrm{C}_{\mathrm{p}}$-q. $\left(\mathrm{GC}_{\mathrm{pi}}\right)$, where $\mathrm{p}$ is wind pressure, the $\mathrm{G}$ Gust factor from Table 2-2, $\mathrm{C}_{\mathrm{p}}$ External pressure coefficient from Figure 2-2, $\mathrm{GC}_{\mathrm{pi}}$ Internal pressure coefficient from Figure 2-2. Source: ASCE 7-10 Eq. 27.4-2

All the load combinations shall be considered for both wind pressure conditions; positive and negative pressures. The proposed roof structure shall be designed to resist the maximum and minimum loads obtained from load combinations. In this regard, a uniformly distributed live load of $20 \mathrm{lb} / \mathrm{ft}^{2}$ is taken according to the Table 1607.1 of the FBC (2010). The self-weight of the system was assumed at the initial design, but was checked when the roof section was sized. The proposed roof has self-weight of 17 pounds per square foot roof area, as is described in the next section. Also a superimposed dead load of $5 \mathrm{lb} / \mathrm{ft}^{2}$ from roof waterproofing and finishes is taken into account in addition to the self-weight of the roof to accommodate the structural load. Table 2-4 lists the critical design loads resulted from loading cases, as well as the maximum values of each pressure as the design loads. Consequently, the new roof system is designed to have adequate strength to withstand negative pressure of $116.25 \mathrm{lb} / \mathrm{ft}^{2}$, and positive pressure of $77.23 \mathrm{lb} / \mathrm{ft}^{2}$, see Table 2-4. The loads determined in this study; however, can accordingly be adjusted for any other topographical regions in accordance with the building code in force. Accordingly, the size of the proposed roof unit section should be adjusted to adapt the loadings. 
Table 2-4 Design Loads Induced by Load Combinations

\begin{tabular}{lcc} 
Load Cases & Positive Pressure $\left(\mathbf{l b} / \mathbf{f t}^{\mathbf{2}}\right)$ & Negative Pressure $\left(\mathbf{l b} / \mathbf{f t}^{\mathbf{2}}\right)$ \\
\hline Load combination 1 & 77.23 & 9.63 \\
Load combination 2 & 74.06 & 99.65 \\
Load combination 3 & 57.46 & 116.25 \\
Design Loads & 77.23 & 116.25 \\
\hline
\end{tabular}

\subsection{Materials of Construction}

Advanced material has been used in bridge and building construction recently (Ahmad et al. 2015; Graybeal 2006). In this study, two advanced materials were utilized for the development and design of the proposed composite roof system: (1) Ultra-High Performance Concrete (UHPC); and (2) High Strength Steel (HSS).

. Ultra-High Performance Concrete (UHPC) has been used in highway bridge construction in the United States since 2006. Glass-fiber reinforced plastic (GFRP), carbon-fiber-reinforced plastic (CFRP) and high strength steel (HSS) bars were utilized with UHPC in bridge decks (Perry and Seibert 2008; Ghasemi et al. 2015 and 2016; Saleem et al. 2011; Xia et al. 2011) however, Ghasemi et al. (2015) concluded that HSS provides noticeable higher strength as opposed to CFRP.

\subsubsection{Slim Design Using UHPC and HSS}

Ultra-High Performance Concrete (UHPC) is a new class of concrete that exhibits remarkable mechanical and durability properties, as compared to the conventional concrete. It is an advanced fiber-reinforced concrete composed of "portland cement, silica fume, quartz flour, fine silica sand, high-range water reducer, water, and steel or organic fibers" (Perry \& Seibert 2008). The constituent components lead to improvements in: (1) mechanical performances; (2) homogeneity; and (3) ductility (Richard and Cheyrezy 1995) as described next. 
For mechanical performance, UHPC offers two exceptional characteristics: (1) high compressive strength, and; (2) high tensile strength, compared to conventional concrete. It has a compressive strength of $20 \mathrm{ksi}$ and greater, which is four to eight times greater than that of conventional concrete, and high tensile-cracking strength of 0.9 to $1.3 \mathrm{ksi}$ (Graybeal $2006,2014)$ - as opposed to 0.3 to $0.7 \mathrm{ksi}$ for normal concrete. Both pre- and post-cracking strength of UHPC are noticeably greater than the conventional concrete (Graybeal 2006). These two significant improvements -- especially tensile strength -- considerably enhance the design of flexural elements made of UHPC (Baqersad et al. 2017). Unlike the approach utilized in the design of traditional reinforced concrete -- that neglects the tensile strength of conventional concrete -- tensile strength of UHPC should be considered in the design process. Tensile strength greatly affects the design and reduces the required section size. Therefore, UHPC's high compressive and tensile strength result in superior flexural strength in a small section size.

Fibers act as the most important constituent component in the UHPC mix. Fiber content enhances the mechanical properties of UHPC especially tensile strength as well as its ductility. High tensile strength of UHPC comes from the fibers content. Fibers act similar to reinforcing steel in conventional reinforced concrete, but on the micro level (Perry 2003, Harris and Roberts-Wollmann 2005). Fibers are distributed all over the mix and provide consistency of tensile strength. The high tensile capacity results in much less need for flexural and shear reinforcement. Additionally, high tensile strength significantly increases the shear strength of UHPC as well, which in turn substantially lower or eliminate the need for shear reinforcement (Baqersad et al. 2017). As a result, fiber content greatly 
promotes the tensile and shear strength and potentially eliminates or reduce the need for reinforcements.

In addition, fibers postpone the formation of micro-cracks, as well as control the crack widths and spacing. This tendency results in increased stiffness of structural elements at service loads. The high service stiffness consequently diminishes service deflection. The high stiffness of UHPC allows engineers to design shallower sections with minimal service deflection that still meet the serviceability limit state requirements specified by the FBC.

Also, fiber content results in a non-brittle ductile material at ultimate capacity (AFGC 2002), which is the result of a fiber pull out mechanism at high loads. The gradual and controlled cracks reduce the "risk of sudden failure" (Richard and Cheyrezy 1995). Ductile behavior of UHPC at ultimate loads provides higher safety to the building users by showing large deflection before failure.

Fine aggregate instead of coarse aggregate combined with optimized granular mixture results in a homogenous, compact, dense superior low porosity cementitious matrix. UHPC's superior low porosity protects steel reinforcing bars from corrosion. Corrosion is one of the major problematic issue affecting most conventional roofs. UHPC provides the proposed roof system a significant high resistance to corrosive environments, much longer life span and subsequently lower maintenance costs. Moreover, in the absence of coarse aggregate, it is practically feasible to construct thin-walled elements using UHPC. Given that little or no reinforcing bars are needed, small size reinforcements can fit in the thin-walled sections.

Additionally, the UHPC's long-term durability makes it an ideal material for severe environmental conditions. The long-term durability expands the longevity of the system, 
as opposed to the conventional concrete, and consequently leads to lower maintenance and life cycle service cost.

Overall, the need for less or no passive reinforcing, high strength - such as flexural, tensile and shear strength- sustained post-cracking tensile strength, fine aggregate, longterm durability, super low porosity, and high ductility, all are beneficial to the design and performance of the proposed UHPC roof system. In conclusion, UHPC is an ideal material that offers noteworthy flexibility to develop novel structural shapes and elements, and eradicates deficiencies with conventional reinforced concrete. All these exceptional features and mechanical properties are paramount to the design of the new UHPC roof, which in turn makes it feasible to effectively develop high-strength lightweight thin-walled low-profile roof system, with little or no ordinary reinforcement. All these features resulted in an environmentally sustainable design.

In this study, Ductal JS1000, a commercially available UHPC product of Lafarge North America, was used to build the experimental specimens. Ductal JS1000 resists external aggressions such as abrasion, pollution, weathering with a longevity of 2 to 3 times the conventional concrete, according to the manufacturer. Table 2-5 lists the proportion of constituent materials, and Table 2-6 presents the mechanical properties provided by the manufacturer.

As reinforcing bars, high strength steel (HSS) enhances UHPC with its remarkable characteristics. In this study, high strength steel -- ChromaX 9100 -- product of MMFX Steel Corporation was implemented as primary reinforcing bars. ChromaX 9100 concrete reinforcing steel has a yield strength of 100 kips, significantly greater than Grade 60 mild steel, and yield strain of $0.4 \%$ (see Fig. 2-3). High yield strength is a great benefit for the 
design and development of thin-walled structural shapes, given the limited space for reinforcing bars in thin-walled. Additional to the strength, ChromaX 9100 reinforcement bar provides five times more corrosion resistance than the conventional steel, according to the manufacturer. This makes it a perfect reinforcing bar for high corrosive environments and extends service life of structures beyond a century with a significant lower life cycle cost.

Table 2-5 UHPC Proportion of Constituent of Materials*

\begin{tabular}{lc}
\hline Constituent Materials & Percentage by Weight \\
\hline Cement & 28.6 \\
Steel Fibers & 6.4 \\
Ground Quartz & 8.5 \\
Silica Fume & 9.3 \\
Fine Sand & 41.1 \\
Water-Reducing Admixture & 0.5 \\
Water & 5.6 \\
\hline
\end{tabular}

*Source: http://www.lafarge-na.com

Table 2-6 Mechanical Properties of Ductal JS1000 UHPC*

\begin{tabular}{lc}
\hline Density & $156 \mathrm{lb} / \mathrm{ft}^{3}$ \\
\hline Compressive Strength & 22 to $26 \mathrm{ksi}$ \\
\hline Tensile Strength & $1.2 \mathrm{ksi}$ \\
\hline Flexural Strength & 4.4 to $5.8 \mathrm{ksi}$ \\
\hline Modulus of Elasticity & $7250 \mathrm{ksi}$ \\
\hline Poisson's Ratio & 0.2 \\
\hline Shrinkage & $<0.00001$ \\
\hline Creep Factor & 0.3 \\
\hline Thermal Expansion Coefficient & $1.18 \times 10^{-5} /{ }^{\circ} \mathrm{C}$ \\
\hline
\end{tabular}

*Source: http://www.lafarge-na.com 


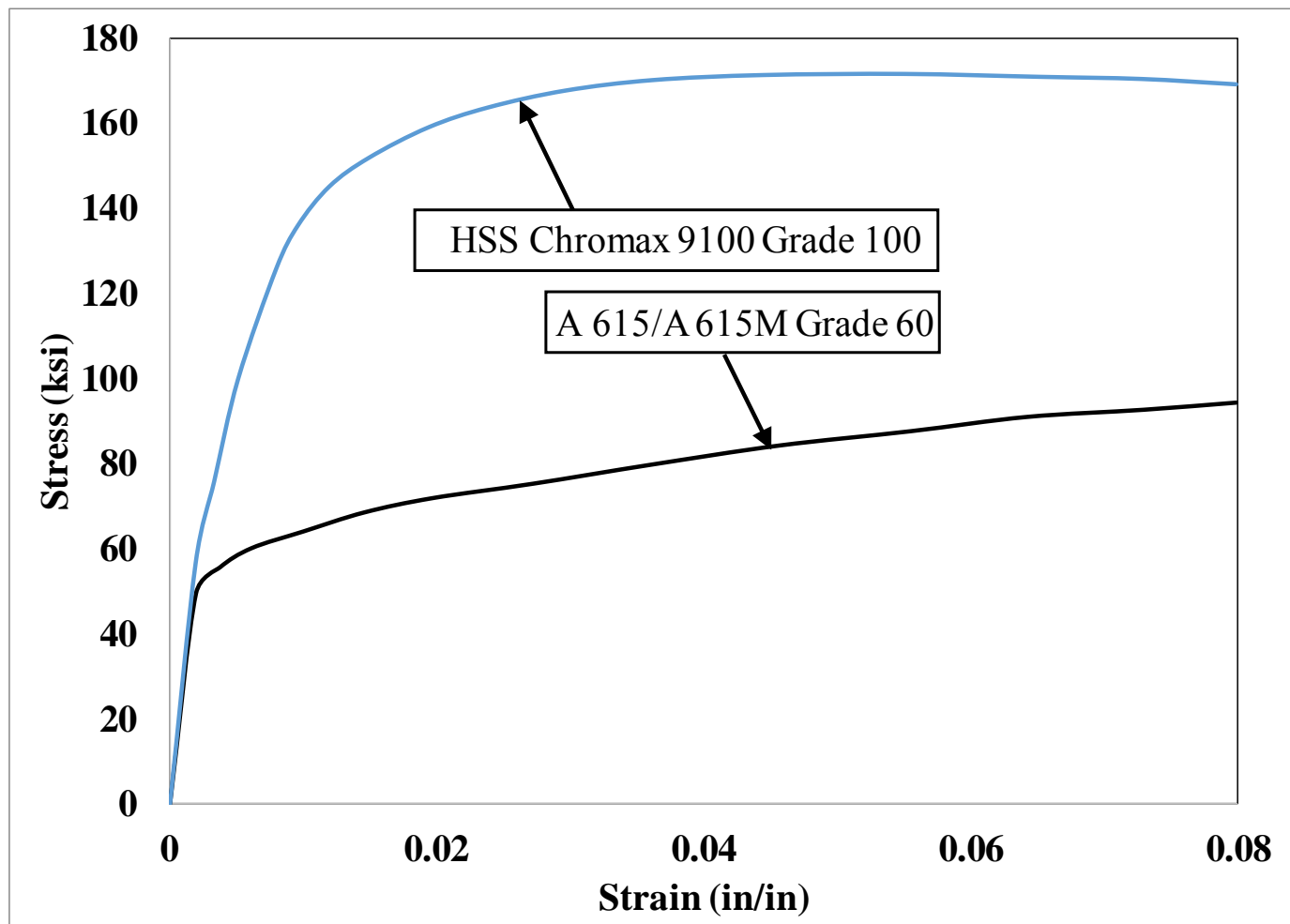

Figure 2-3 Stress-Strain responses of high strength steel (HSS), ChromaX 9100, and steel grade 60

The exceptional mechanical properties and durability of UHPC and HSS, as stated earlier, make this material combination ideal for the current study. This combination resolves all the basic weaknesses of reinforced concrete, and brings a new solution to the roofing industry. In this study, the effort was made to effectively utilize superior mechanical and durability properties of both materials, UHPC and HSS, to develop an innovative durable lightweight thin-walled low-profile wind-resistant composite roof deck as a new practice for new constructions as well as a replacement of existing roofs.

\subsection{System Design}

The crucial step of development was to determine the appropriate shape of the roof unit, then size the shape to resist both positive and negative bending effectively. 


\subsubsection{Section Shape}

Mintz et al. (2015 \& 2016) proposed a corrugated concrete roof primarily for residential buildings. Their proposed "Super-Tile" system mimicked the shape of aesthetically pleasing barrel-type tile roofs, prevalent in sloped gable- or hip-roof residential buildings in the South. This study expands the same idea to industrial, commercial or multi-story residential buildings, but with flat roof system.

Figure 2-4 introduces the cross-sectional shapes considered initially in this study, based on the concept of "Super-Tile" roof system (Mintz et al. 2015 \& 2016). Total of four roof unit shapes, shown in Figure 2-4, were investigated for feasibility. Among those, the first one was considered the most appropriate case for the current study based on two criteria: strength and weight. It is flat on top; light in weight by eliminating less effective material in the center; and strong by focusing on top and bottom of the section to maximize the section properties. Figure 2-5 shows the modified shape considered for the development of the new roof system in this study. 


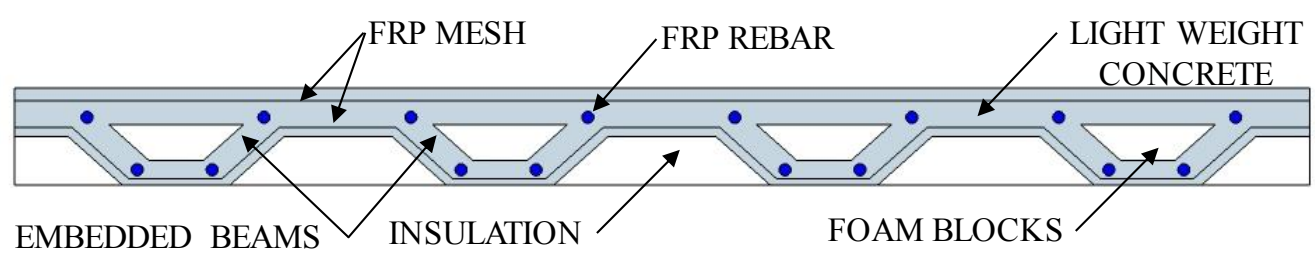

$\underline{(a)}$

CONFIGURATION 1

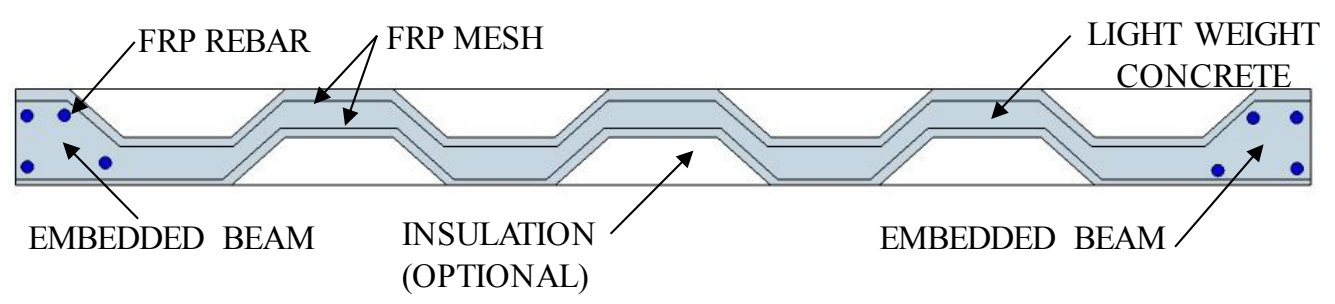

(b)

CONFIGURATION 2

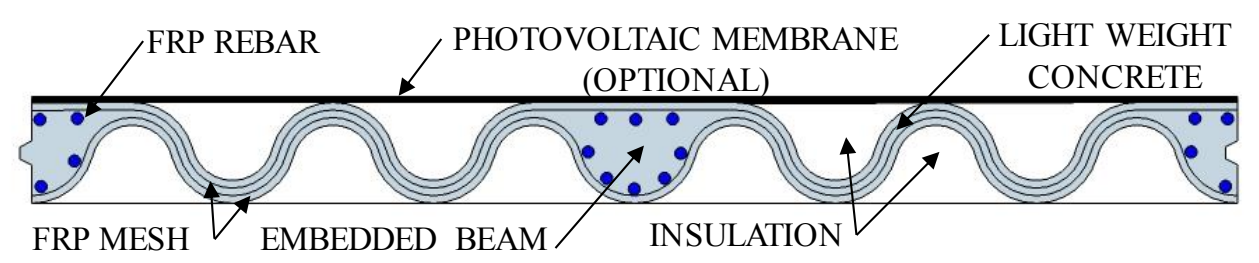

(c)

CONFIGURATION 3

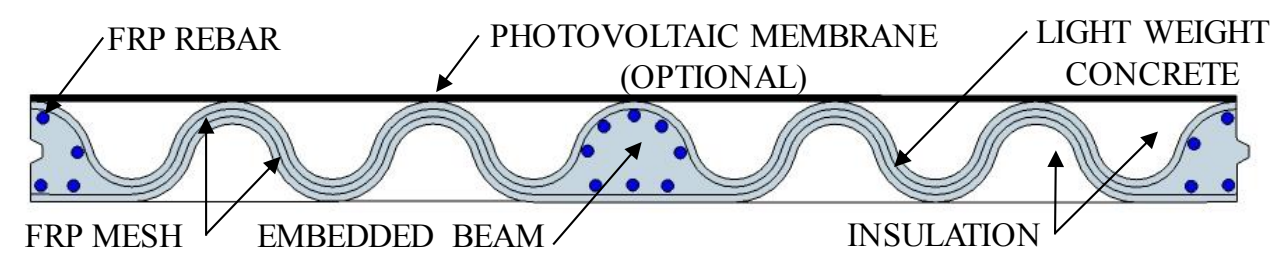

(d)

CONFIGURATION 4

Figure 2-4 The cross-sectional shapes initially considered for the development of the new roof system 


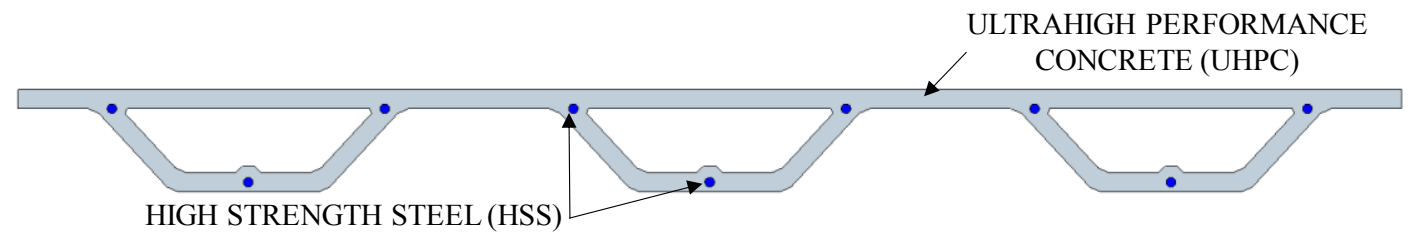

Figure 2-5 The initial cross-sectional shape considered for the development of the new roof system

The structural strength can be maximized while the self-weight is minimized. Excess material in the center of the cross section is eliminated -- where UHPC has the least contribution to the section's strength - to result in a lightweight profile. By focusing on top and bottom of the section -- where high stresses occur-- trapezoidal shape can offer higher area moment of inertia. This structural shape also provides flexibility in sizing, in which the top and bottom flange can be proportioned appropriately to handle any magnitude of positive and negative loading effectively. The trapezoidal section should resist negative loading about 1.5 times of the positive loading-- estimated based on the design loads of 77.23 and $116.25 \mathrm{lb} / \mathrm{ft} 2$, determined previously. In the case of negative loading (upward pressure), top flange acts in tension. Thus, the wide top flange reinforced with HSS bars can provide the section with higher tensile strength needed for high negative loading pressure. Whereas, with the consideration of lower demand capacity in positive loading, the narrow bottom flange with a single HSS bar can provide the required tensile strength.

The wide top flange also acts as roof deck as needed for the flat roof, as well as providing room for more reinforcing bars required in high upward loading. The two webs support the wide-strong top flange for high loading amounts. Also, the proposed crosssectional shape has efficient load distribution in transverse direction. The groove in the 
bottom flange provides room for reinforcing bars, and chamfers at the sharp corners increases load-bearing by preventing stress concentration.

As result, the appropriate proportion of flanges' width and thickness can create a cross section with the most optimized section properties that are effectively functional in handling both loading conditions; while it is still light in weight, and needs minimal material (e.g. UHPC) for construction. The proposed structural shape is flexible in sizing to accommodate different loading magnitudes other than those considered in this study.

\subsubsection{Roof Geometry}

Figure 2-6 illustrates the 3D schematic of the proposed new roof system. It is determined by a series of trapezoidal thin-walled sections with a trapezoidal hollow inner section, termed as box-cells in this study, manufactured in a monolithic deck with the desired number of box-cell units. It is also featured with full-depth I-section transverse ribs at intermediate locations, as needed, to distribute the imposed loads uniformly on the entire roof panel. The ribs do not run through the box-cells, leaving hollow channels to accommodate electrical, plumbing, and mechanical systems - a useful feature to improve constructability of commercial and industrial buildings.

\subsubsection{Slab Action}

The proposed roof panel is designed to perform as a one-way slab, spanning roofs in one direction along the shorter length. Figure 2-7 represents the configuration and structural action of the proposed roof panels. As depicted in the figure, the new roof bends and distributes imposed loads in one direction, and only curves perpendicular to the supporting beams or walls, while its deflection profile is constant along the longer span, 
$\mathrm{L}_{\mathrm{b}}$. This action results in uni-axial bending moment along the panel's length. Therefore, based on one-way slab structural performance, roof panels can be considered to act as a series of beams, box-cells, spanning between supporting beams or walls. Based on this concept, box-cell units are engineered according to beam analogy.

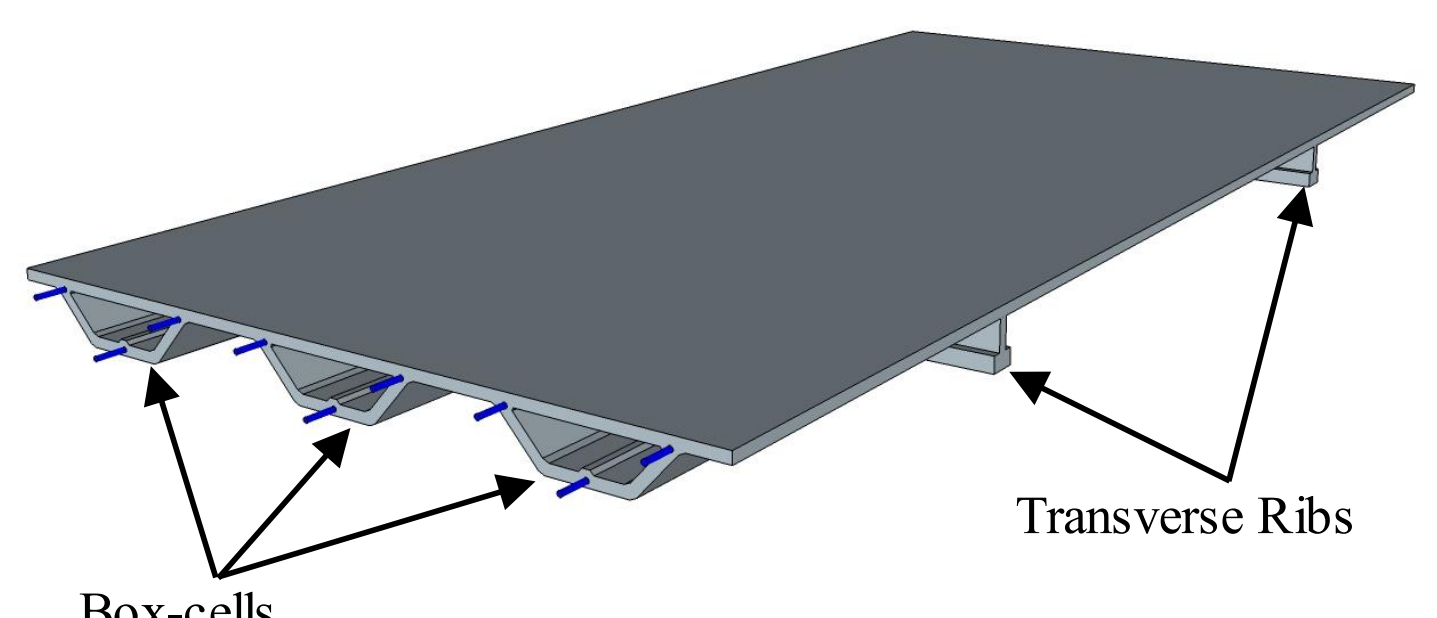

(a)

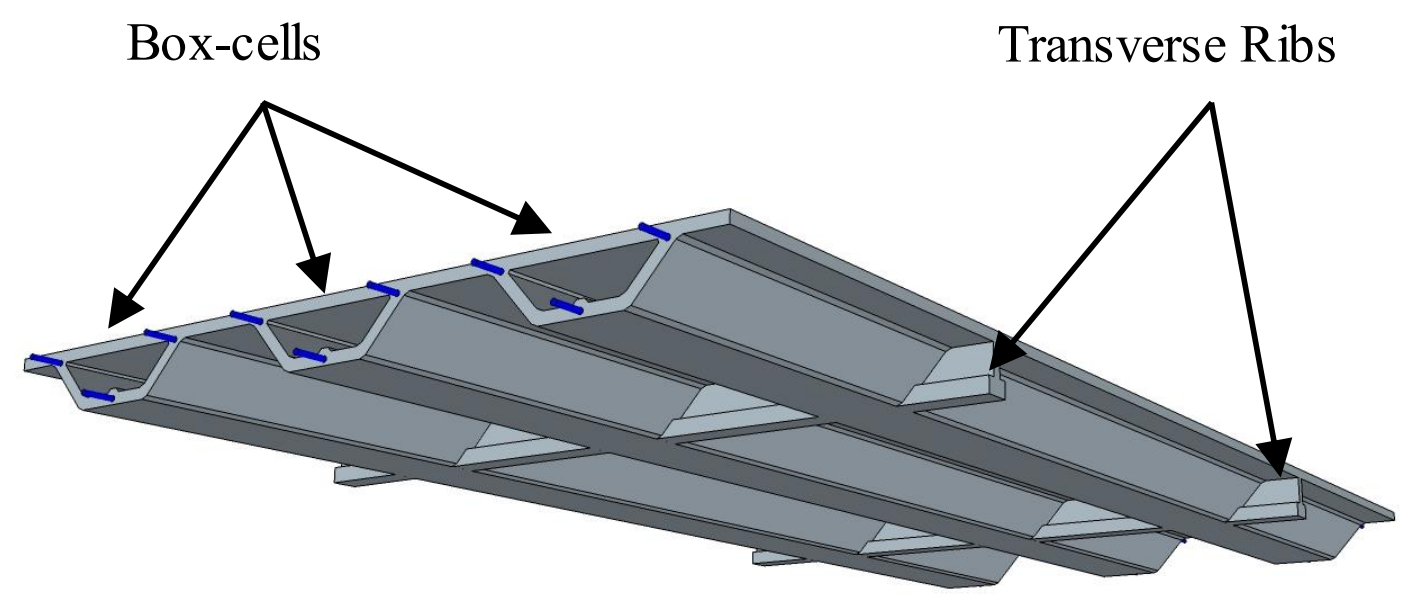

(b)

Figure 2-6 Isometric views of the proposed roofing system: (a) Top view; (b) Bottom view 


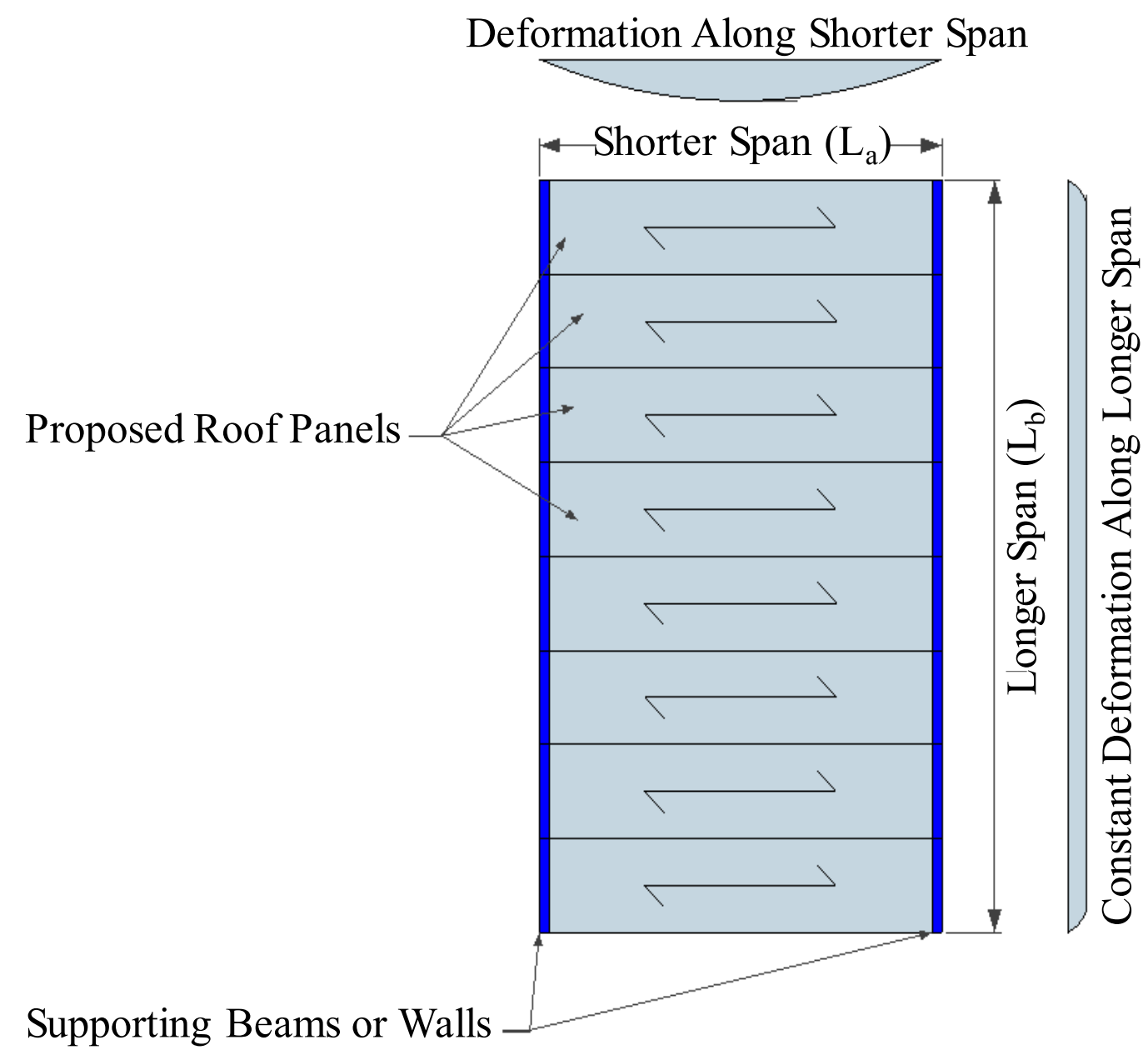

Figure 2-7 Structural action of the proposed roof system

\subsubsection{Section Properties}

As described earlier, the proposed box-cell section was engineered with the purpose of maximizing strength and stiffness and minimizing the weight, while handling both imposed loads - positive and negative - in an optimal way. In order to size the section, a 20-foot long span was selected as the case study. This particular span length was selected because the typical framing in commercial buildings varies between $15 \mathrm{ft}$. and $30 \mathrm{ft}$. A single box-cell section was sized appropriately to have adequate strength and stiffness with regard to both pressures -- 77.23 and $116.25 \mathrm{lb} / \mathrm{ft}^{2}$ of positive and negative pressure, 
respectively. Figure 2-8 illustrates the geometric details of the engineered box-cell section utilized in this study.

The proposed box-cell section is 18 in. wide in top flange, 6 in. wide in bottom flange, with an overall depth of only 4 inches. It is a thin-walled section with only $3 / 4$ of inches-thick webs and flanges. This is the minimum thickness in order to avoid punching shear failure, according to the recommendation by Harris and Roberts-Wollman (2005). Also, it is almost the thinnest constructible structural thickness that can be built using UHPC. The $3 / 4$-inch.thickness can also retain constructability, as is discussed in the next chapter. The proposed box-cell section is reinforced with only three No. 3 HSS bars - the smallest standard size rebar in the market. It is reinforced with one rebar in the bottom flange and two at the crossing of top flange and webs. The bottom flange is only $3 / 4$ in. deep, and the No. 3 reinforcing bar is slightly larger than $3 / 8$ in. in diameter including deformations, which occupies half of the thickness. The groove in the bottom flange can accommodate larger rebar sizes in case the given section is used for different loading demands than those considered in this study. Also, the high tensile and shear strength of UHPC led to total elimination of shear reinforcement and stirrups.

As a result, the combination of two advanced materials - UHPC and HSS enhanced with an efficient structural shape - box-cell - resulted in a section that is:

(a) lightweight (only $17 \mathrm{lb} / \mathrm{ft}^{2}$ ),

(b) low-profile with only 4 inches depth,

(c) ultra-thin-walled with only $3 / 4$-inch thick walls,

(d) without transverse reinforcement or shear stirrups. 
All these listed features are significant improvements compared to the same capacity conventional reinforced concrete section. Chapter 6 specifically discusses the advantages of these improvements in more details.

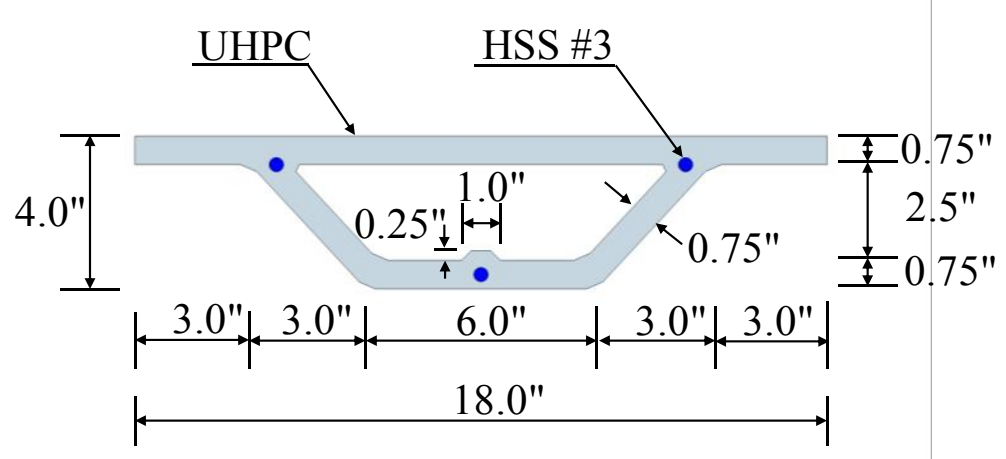

Figure 2-8 Geometric details of the engineered box-cell section 


\title{
CHAPTER 3
}

EXPERIMENTAL APPROACH TO ASSESS THE ULTIMATE LIMIT STATES

\author{
OF THE NEW ROOF SYSTEM
}

\subsection{Introduction}

This chapter specifically outlines the experimental evaluation of the flexural and shear strength of the proposed wind-resistant engineered flat-roof system at ultimate limit state (ULS).

\subsection{Flexural Strength}

\subsubsection{Experimental Work}

The test matrix included two groups of specimens tested in two consecutive phases: Group 1 were single box-cell specimens tested as roof components (see Figure 3-1), whereas Group 2 were multi-cell specimens made of three monolithically cast box-cells forming a representative roof panel (see Figure 3-2). For each group two identical specimens were tested in four-point bending. One was tested in positive bending to represent Load Combination 1 (see Table 3-1), consisting of live and dead loads along with net downward wind pressure. The other one was tested in negative bending to represent Load Combination 2, consisting of net uplift wind pressure and dead loads. 
Table 3-1 Design Loads

Type of Loads

Live load ${ }^{\text {a }}$

Superimposed dead load ${ }^{\mathrm{b}}$

Dead weight of the proposed roof system

Positive wind pressure ${ }^{\mathrm{c}}$

Negative wind pressure ${ }^{\mathrm{c}}$

Factored load combinations

Load Combination 1: $1.2 \mathrm{D}+1.6 \mathrm{~L}+0.5 \mathrm{~W}^{\mathrm{d}}$

Load Combination 2: $0.9 \mathrm{D}+1.0 \mathrm{~W}^{\mathrm{e}}$
Magnitude (lb/ft $\left.{ }^{2}\right)$

20.0

5.0

17.0

37.7

136.1

77.2

116.3

a According to the Florida Building Code, Table 1607.1;

$\mathrm{b}$ Typical superimposed dead load due to roof finishes;

${ }^{\mathrm{c}}$ Calculated based on ASCE-7 for a flat roof building with a mean roof height of $50 \mathrm{ft}$.;

${ }^{\mathrm{d}}$ Load combination from the Florida Building Code, Equation (16-3);

${ }^{\mathrm{e}}$ Load combination from the Florida Building Code, Equation (16-6).

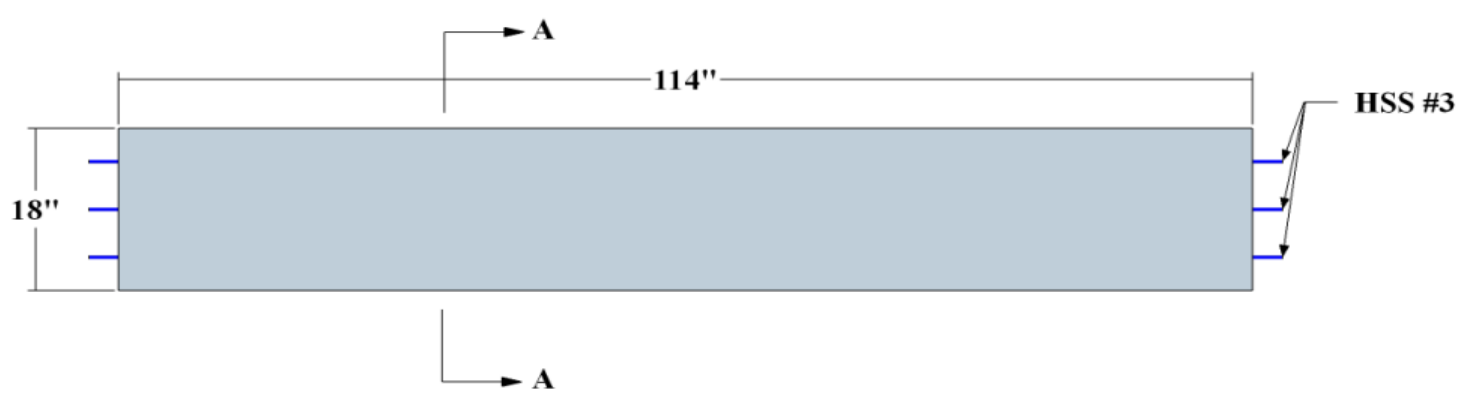

(a)

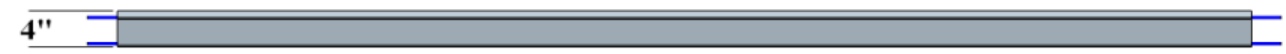

(b)

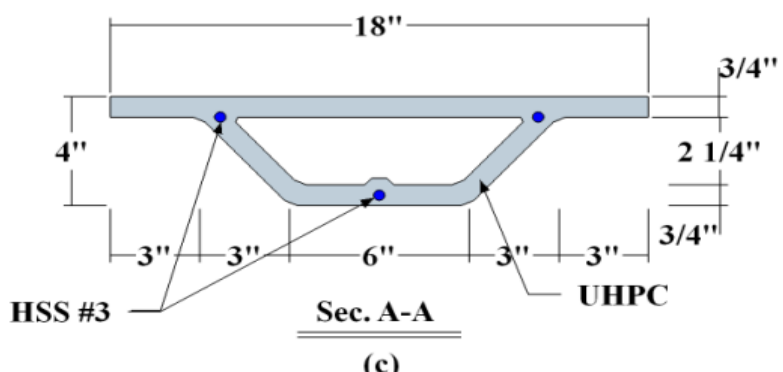

(c)

Figure 3-1 Schematic of Single-cell Specimen: (a) Plane view; (b) Side view; (c) Cross-section 


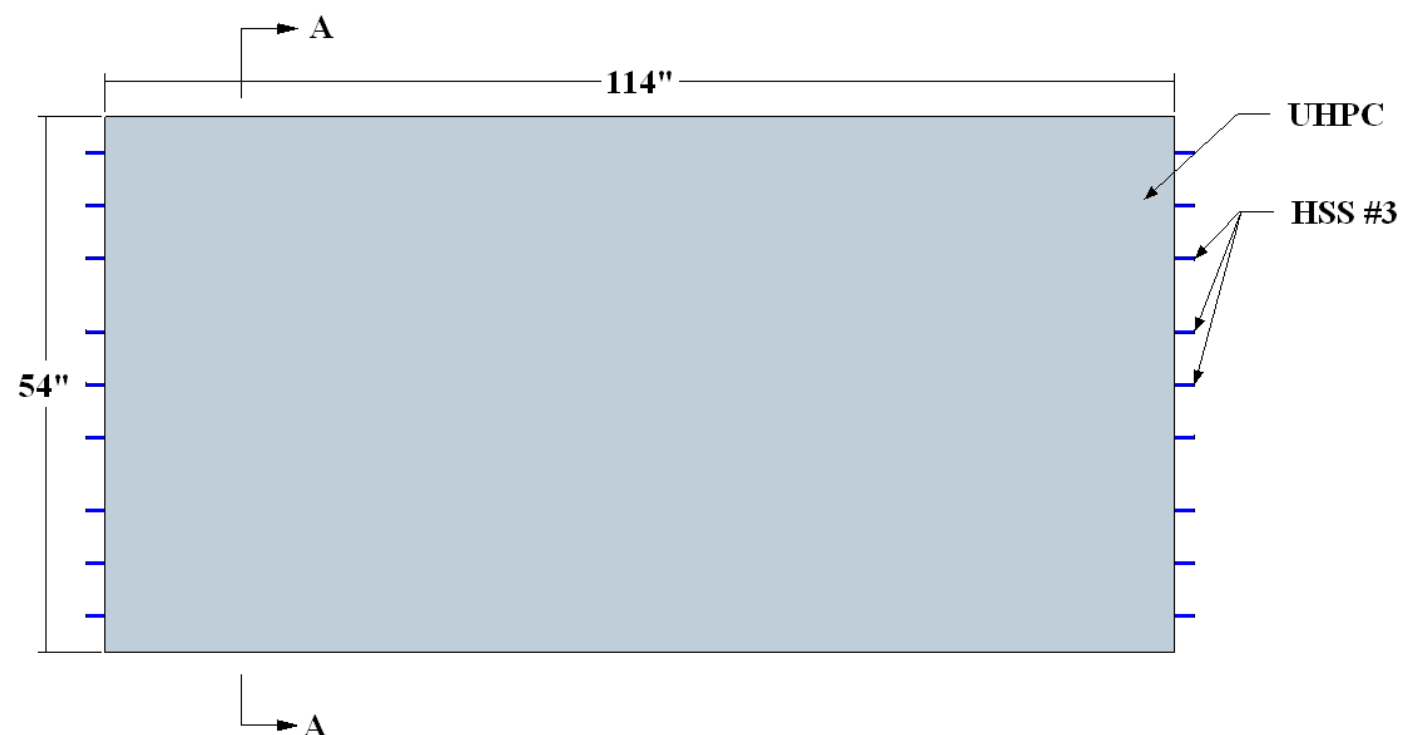

(a)

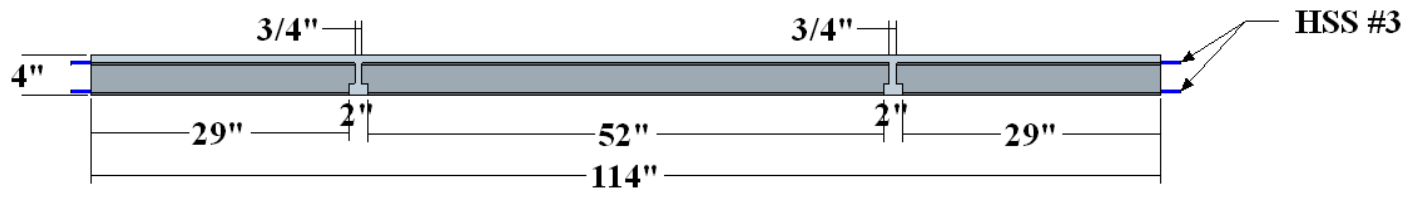

(b)

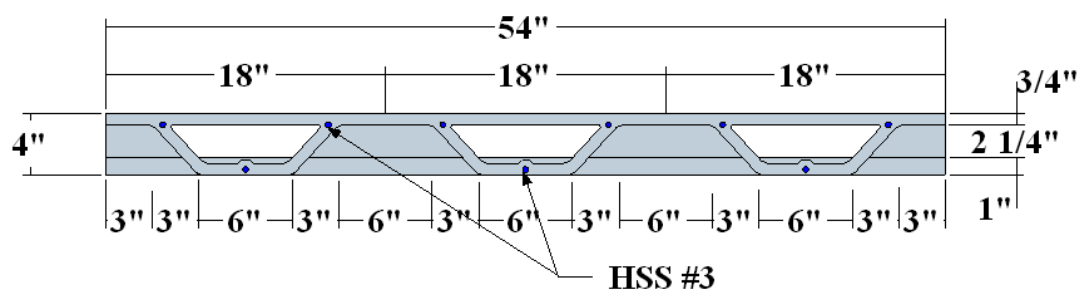

Sec. A-A

(c)

Figure 3-2 Schematics of Multi-cell Specimen: (a) Plan view; (b) Side view; (c) Cross-section

\subsubsection{Test Matrix}

Table 3-2 summarizes test specimens in the two groups. All specimens were 114 in. long due to laboratory constraints. The single-cell specimens in Group 1 were 18 in. wide and 4 in. deep with $3 / 4$ in. thick webs and flanges, see Figure $3-1$. Specimens were 
reinforced using three Grade 100 HSS No. 3 bars, with one bar placed in the bottom flange and the other two in the top flange. The multi-cell specimens of Group 2 were 54 in. wide with an aspect ratio of 2:1, and two transverse ribs at the quarter points along the span, as shown in Figure 3-2. Specimen names represent the specimen type (SC and MC for singlecell and multi-cell, respectively), followed by the loading configuration ( $\mathrm{P}$ and $\mathrm{N}$ for positive and negative bending, respectively).

Specimens were prepared with Ductal ${ }^{\circledR}$, a commercially available UHPC product, made by Lafarge North America. It is composed of a premix powder (cement, silica fume, ground quartz and sand), water, superplasticizer, and metallic fibers. The fibers represented $2 \%$ of the mix by volume, and were $1 / 2$ in. in length, with a nominal diameter of $0.01 \mathrm{in}$., and a tensile strength of $406 \mathrm{ksi}$.

As previously stated, ChrōmX 9100 No. 3 HSS bars of MMFX® Steel Corp. were used as primary reinforcement. The bars had a yield strength of $100 \mathrm{ksi}$ and a corresponding yield strain of $0.4 \%$. The reinforcement is specified as ASTM A1035 CS, combining high strength properties with high corrosion resistance. It also offers tensile strength to yield ratios of over 1.25, which is a noteworthy improvement in the area of ductility in comparison to other high-strength steel bars. Table 3-3 lists the physical properties of ChrōmX 9100 reinforcing bars, as provided by the manufacturer. 


\begin{tabular}{|c|c|c|c|c|}
\hline \multirow[t]{2}{*}{ Item } & \multicolumn{2}{|c|}{$\begin{array}{c}\text { Group 1 } \\
\text { (Single-cell) }\end{array}$} & \multicolumn{2}{|c|}{$\begin{array}{c}\text { Group } 2 \\
\text { (Multi-cell) }\end{array}$} \\
\hline & SC-P & SC-N & MC-P & MC-N \\
\hline 1.) & 4 & 4 & 4 & 4 \\
\hline & - & - & 4.5 & 4.5 \\
\hline hickness (in.) & $3 / 4$ & $3 / 4$ & $3 / 4$ & $3 / 4$ \\
\hline ive Strength* (ksi) & 20.2 & 21.8 & 18.9 & 18.4 \\
\hline Slab & No. 3 & No. 3 & No. 3 & No. 3 \\
\hline Rib & - & - & - & - \\
\hline
\end{tabular}

Overall Depth (in.)

Rib Spacing (ft)

Flange \& Web Thickness (in.)

UHPC Compressive Strength* (ksi)

Flexural Reinforcement $\quad$ Slab

*See Table 3-4 for the breakdowns

Table 3-3 Material Properties of ChrōmX 9100 Reinforcing Bar*

\begin{tabular}{lc}
\hline Bar No. & No. 3 \\
\hline Diameter (in.) & $3 / 8$ \\
\hline Area $\left(\mathrm{in}^{2}\right)$ & 0.11 \\
\hline Weight (lb/ft) & 0.376 \\
\hline Tensile Strength (ksi) & 150 \\
\hline Yield Strength (0.2\% offset), (ksi) & 100 \\
\hline Min. Elongation for 8 in., (\%) & 7 \\
\hline
\end{tabular}

*Source: htt://www.mmfx.com

\subsubsection{Specimens Fabrication}

Testing specimens were cast in formwork made of Styrofoam. In practice, the trapezoidal hollow inner core was provided by suspending a floating foam core in the center of the base platform of Styrofoam, creating a void when removed after UHPC has set. In the fabrication of single-cell specimens, the foam core was suspended by threaded rods attached to an aluminum square tube embedded in the foam core, as shown in Figure 3-3. The threaded rods allowed the foam core to be precisely adjusted, while restraining it from the dynamic forces of pouring concrete. The fabrication of the multi-cell specimens was done using threaded rods tied down to the wooden base as shown in Figure 3-4. Placement was critical as webs and flanges were only $3 / 4$ in. deep. Any minute movement of the core 
could have resulted in a diminished cross sectional area of a web or flange and/or exposed longitudinal reinforcing steel.

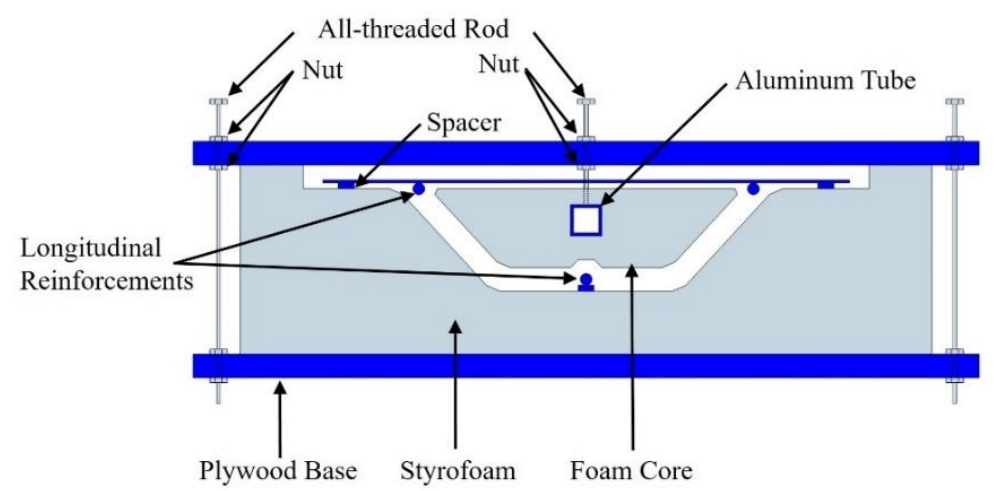

(a)

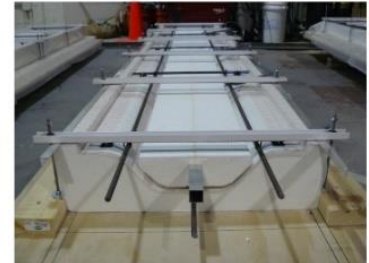

(b)

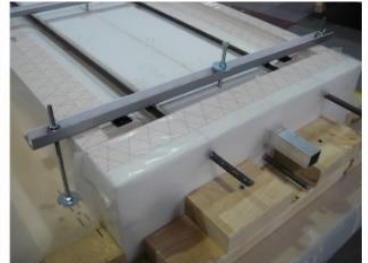

(c)

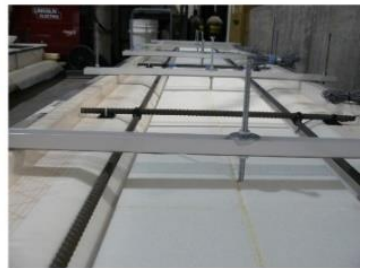

(d)

Figure 3-3 Formwork made of Styrofoam for single-cell specimens

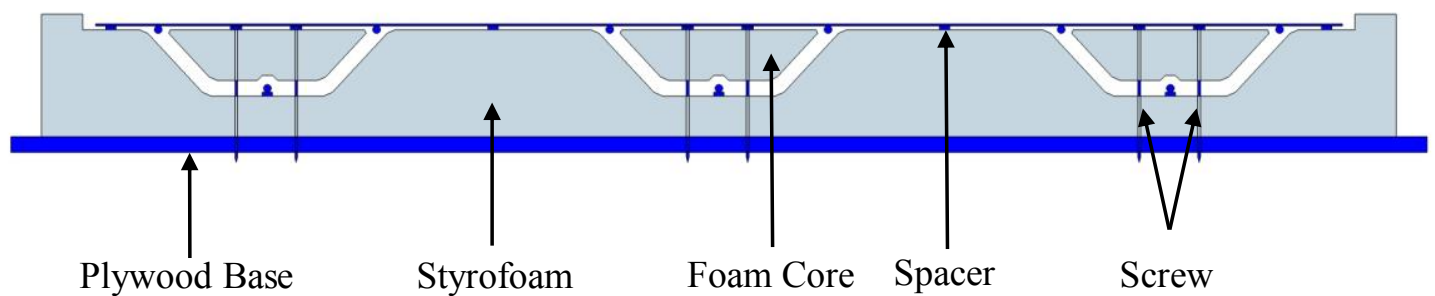

(a)

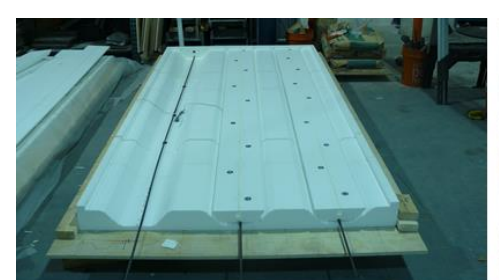

(b)

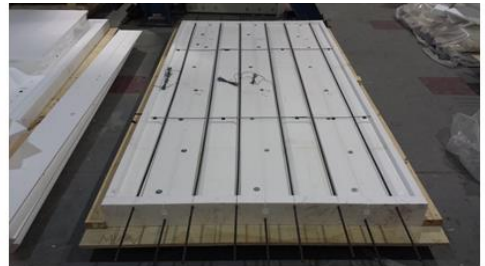

(c)

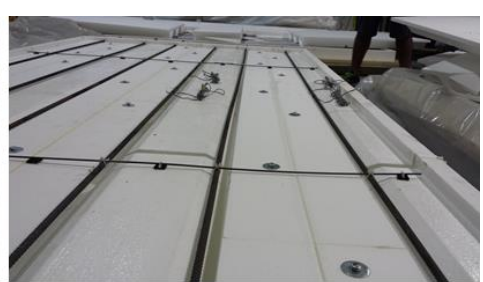

(d)

Figure 3-4 Formwork made of Styrofoam for Multi-cell panel specimens 
Figures 3-5 and 3-6 show the casting process for single-cell and multi-cell specimens, respectively. Specimens were cast and fabricated as single monolithic units, as shown in Figures 3-7 and 3-8. The first UHPC mixing aimed for SC-P specimen for which it was elected to mix enough concrete in one load. The mixer was not powerful enough for purposes of mixing UHPC in some instances, due to its mechanical trouble turning the dense mix. The cementitious constituent and fine aggregates as well as steel fibers appear to have exerted undue strain on the equipment. Additionally, due to the high ambient temperature some water content was lost to evaporation. It was unclear exactly how much water was lost, consequently sufficient amount of water, totally three pound additional, was added to compensate for the evaporated $\mathrm{H}_{2} \mathrm{O}$. Later, a proper mixer was employed for SC-N and multi-cell panel specimens to avoid the earlier issue. Multi-cell panel specimens were cast using four UHPC batches. UHPC paste was poured into the molds from one end flow freely to the other end to let uniform fibers distribution align with specimens' length. Fibers direction influences flexural behavior. The mixtures had great workability and selfconsolidating characteristics to flow through the $3 / 4$ in. ultra-thin webs and flanges. Therefore, no screed and internal or external vibration were implemented.

All specimens were cured and stored in a temperature controlled room with an average temperature of $68^{\circ} \mathrm{F}$ and covered with plastic sheets for 14 days to avoid moisture content evaporation. This was done to ensure adequate strength, although UHPC demonstrates high compressive strengths irrespective of the curing treatment applied (Graybeal 2006). During the initial 28-day curing, it was apparent that some mild flaws had developed in the first single-cell specimen, SC-P. There were periodic lateral hairline 
cracks spanning the width of the top flange (See Fig. 3-9). The cracks were attributed to shrinkage, due to added water in the mix. However, the cracks had no effect on flexural capacity, since the specimen was tested in positive bending configuration, in which the top flange was in compression and the cracks remained tight during the test. No sign of shrinkage cracks were found on the other testing specimens.

During the casting, $3 \times 6$ in. cylinder samples were cast from each batch of UHPC, as it was poured into forms-- acceptable cylinder size for compressive strength measurement according to Graybeal and Davis (2008). Cylinders from the first batch were ground for testing, slightly exposing the inner concrete. There were small unreacted clumps of Portland cement in the hardened concrete matrix, as shown in Figure 3-10. These were a result of a lack of experienced construction personnel and selection of improper mixing equipment, as previously discussed. That issue was avoided by selecting a larger and more powerful mixer for other specimens to ensure adequate dry premixing of the Portland cement, as was required by the proprietary mix design and procedure. Compression cylinders were tested at 28 day strengths. Loads were measured continuously until the specimens failed. The maximum values for each cylinder are shown in Table 3-4 along with the respective average 28-day compressive strength of each testing specimen.

One of the inherent characteristics of UHPC is an immaculate form-side finish. The top side of the specimens occasionally was dotted with air bubbles which had risen to the surface. Also, an occasional steel fiber protruded through the top of the slab. For economical production and to ensure the integrity of waterproofing membranes, it is recommended that commercially produced units be poured upside down. In this fashion, the top, roofed surface will retain a smooth, form-side finish. Additionally, cost savings by 
eliminating probable grinding will be gained as the bottom side is normally covered by interior ceiling finishes. More importantly, additional structural strength will be gained, because the fibers segregate in the top flange due to gravity, where high tensile strength is needed to resist high uplift wind pressure.
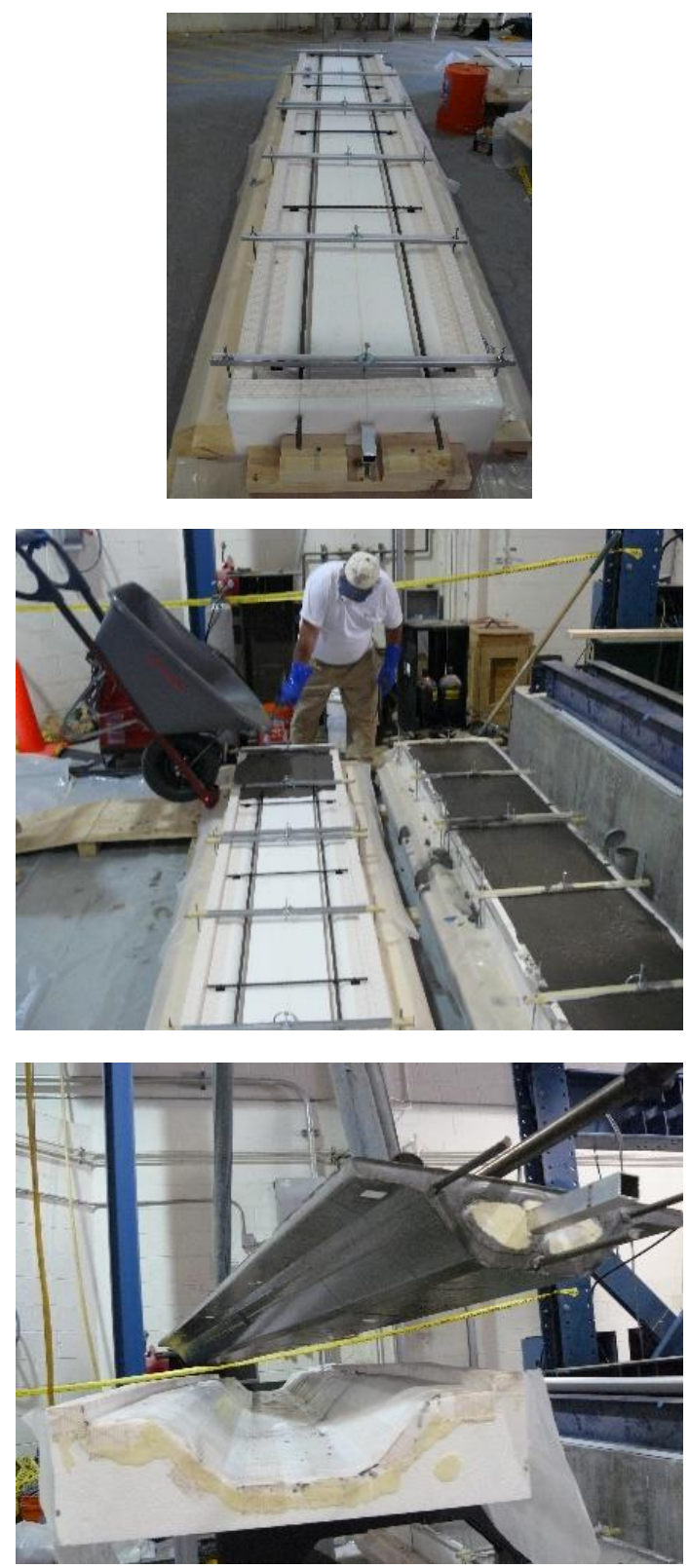

Figure 3-5 Single-cell specimens preparation 


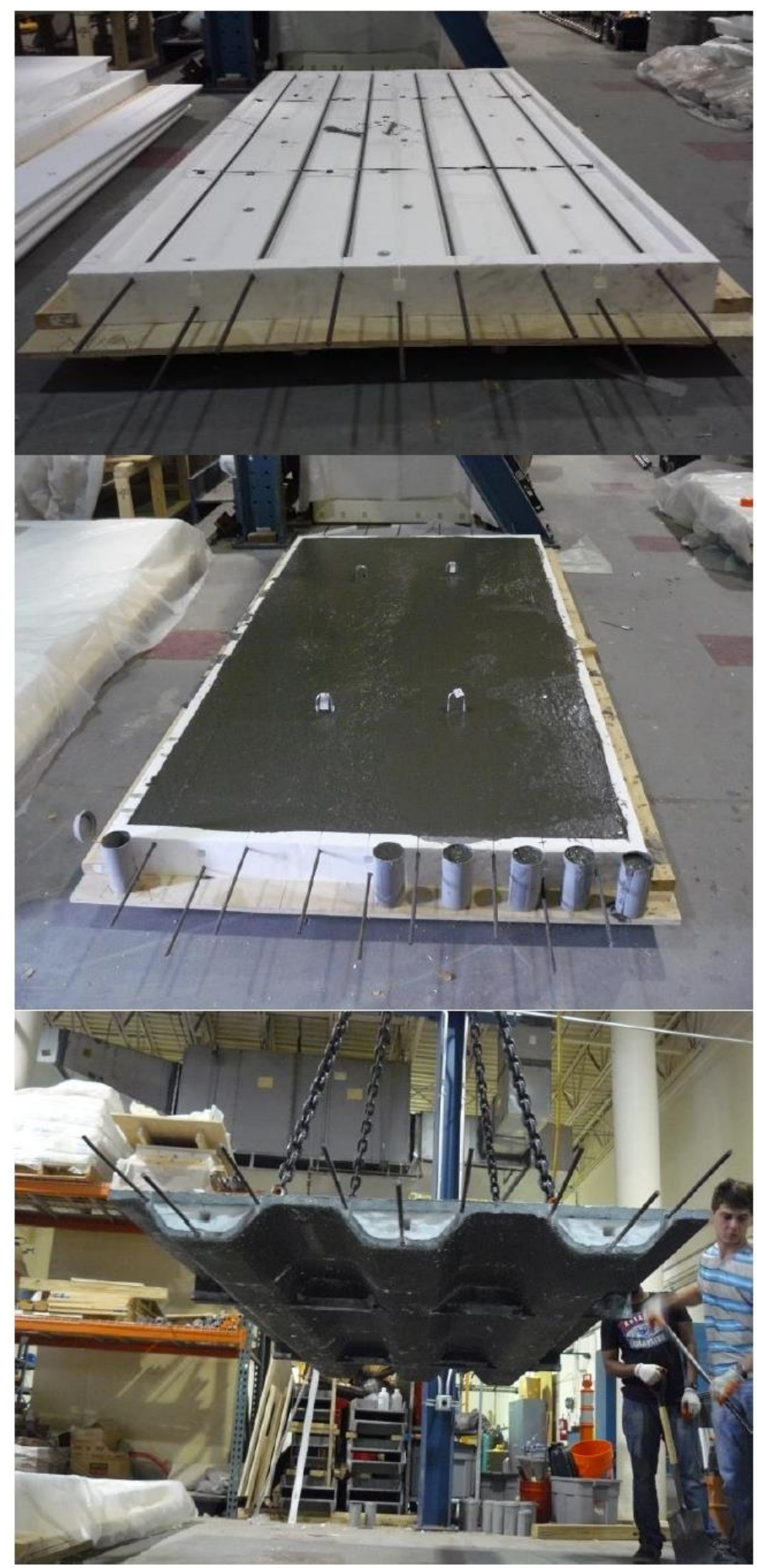

Figure 3-6 Multi-cell specimens preparation 


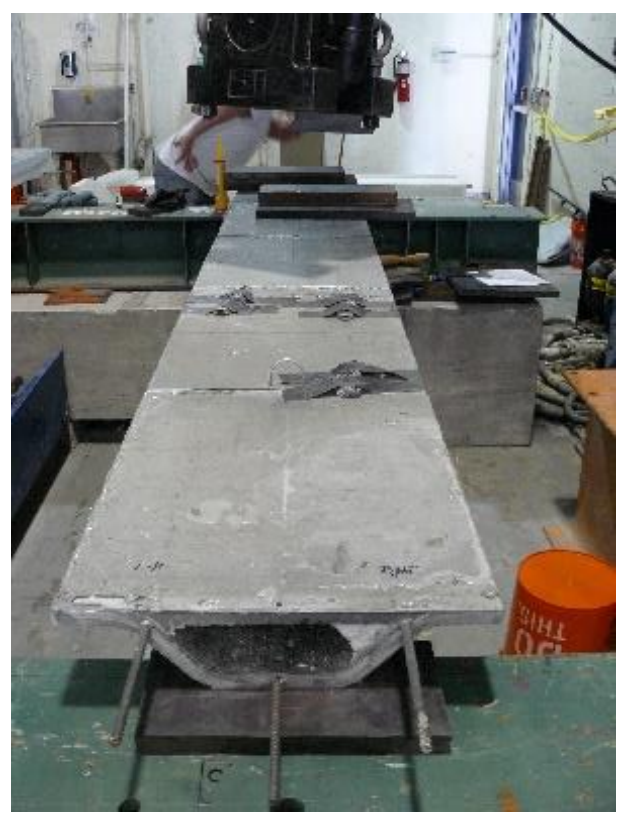

(a)

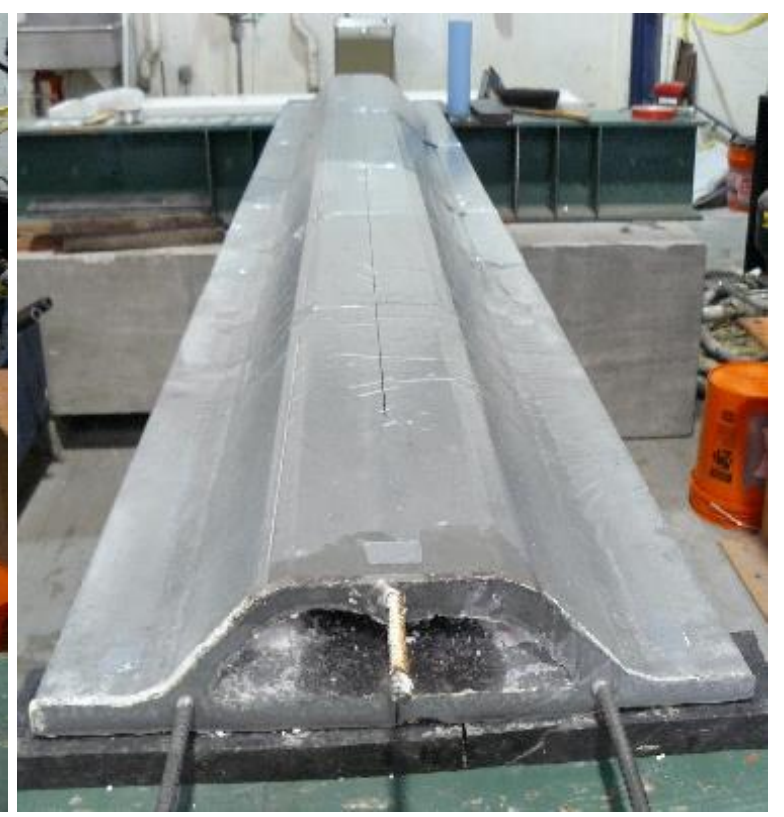

(b)

Figure 3-7 Single-cell specimens: (a) SC-P; (b) SC-N

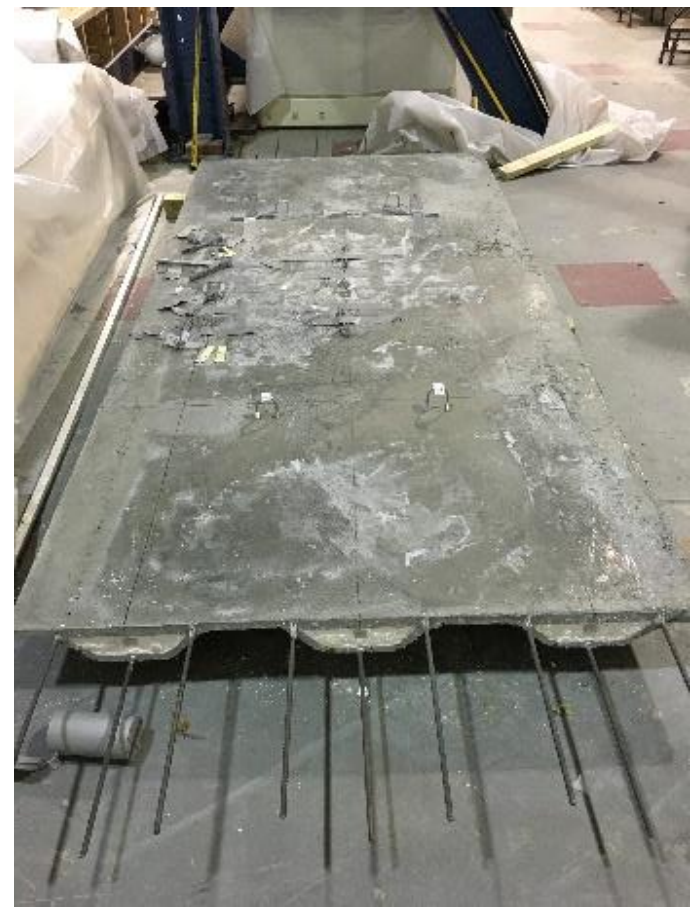

(a)

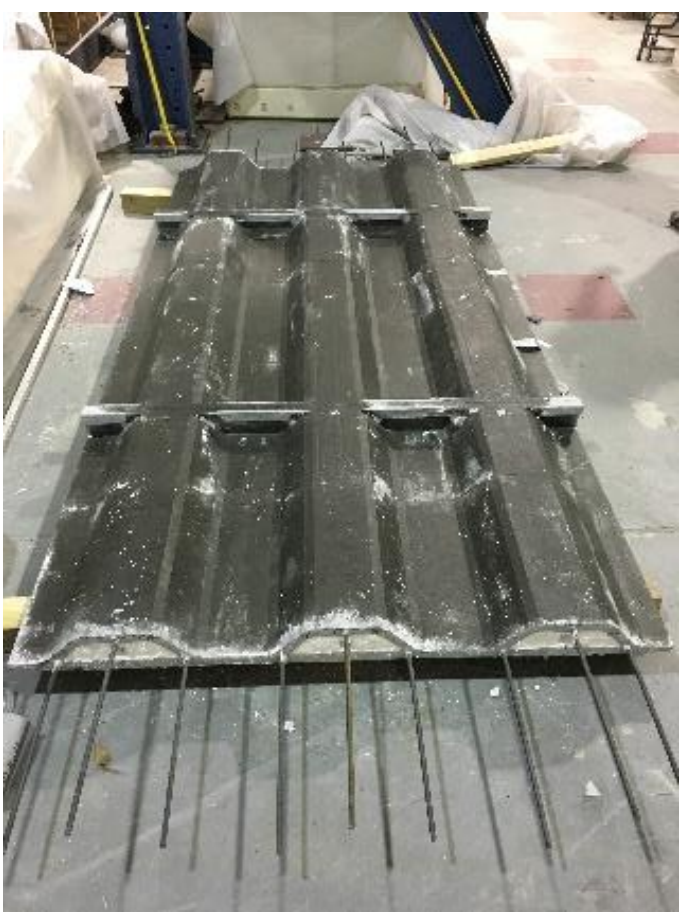

(b)

Figure 3-8 Multi-cell panel specimens: (a) MC-P; (b) MC-N 

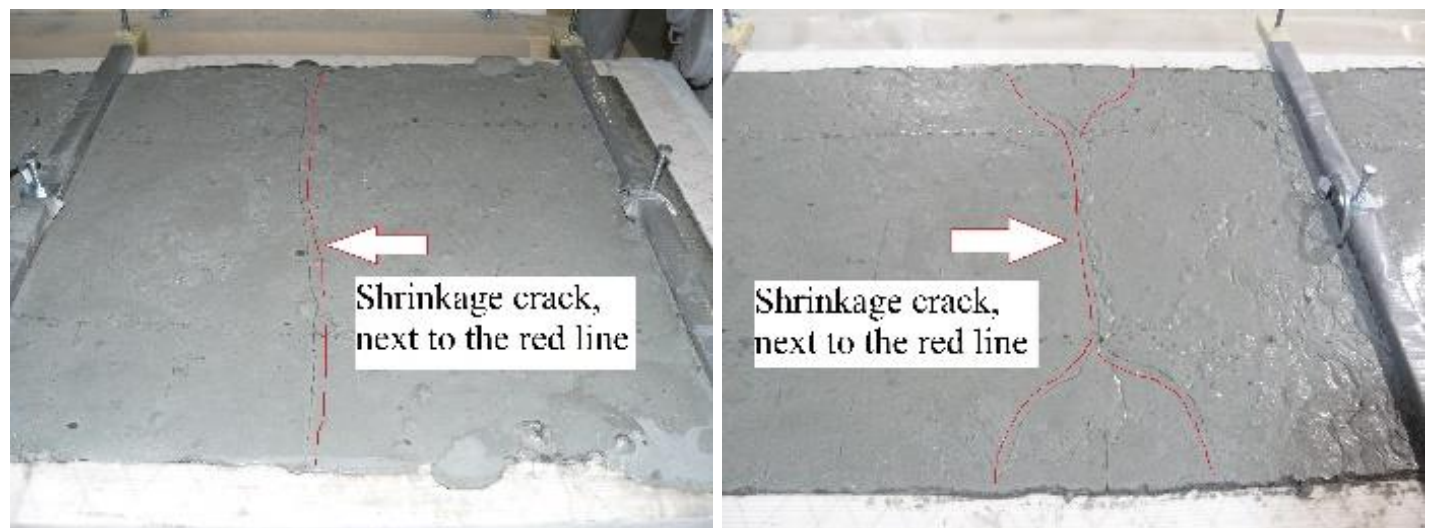

Figure 3-9 Lateral shrinkage cracks on the top flange of SC-P specimen due to the high $\mathrm{w} / \mathrm{c}$ ratio in the UHPC mix

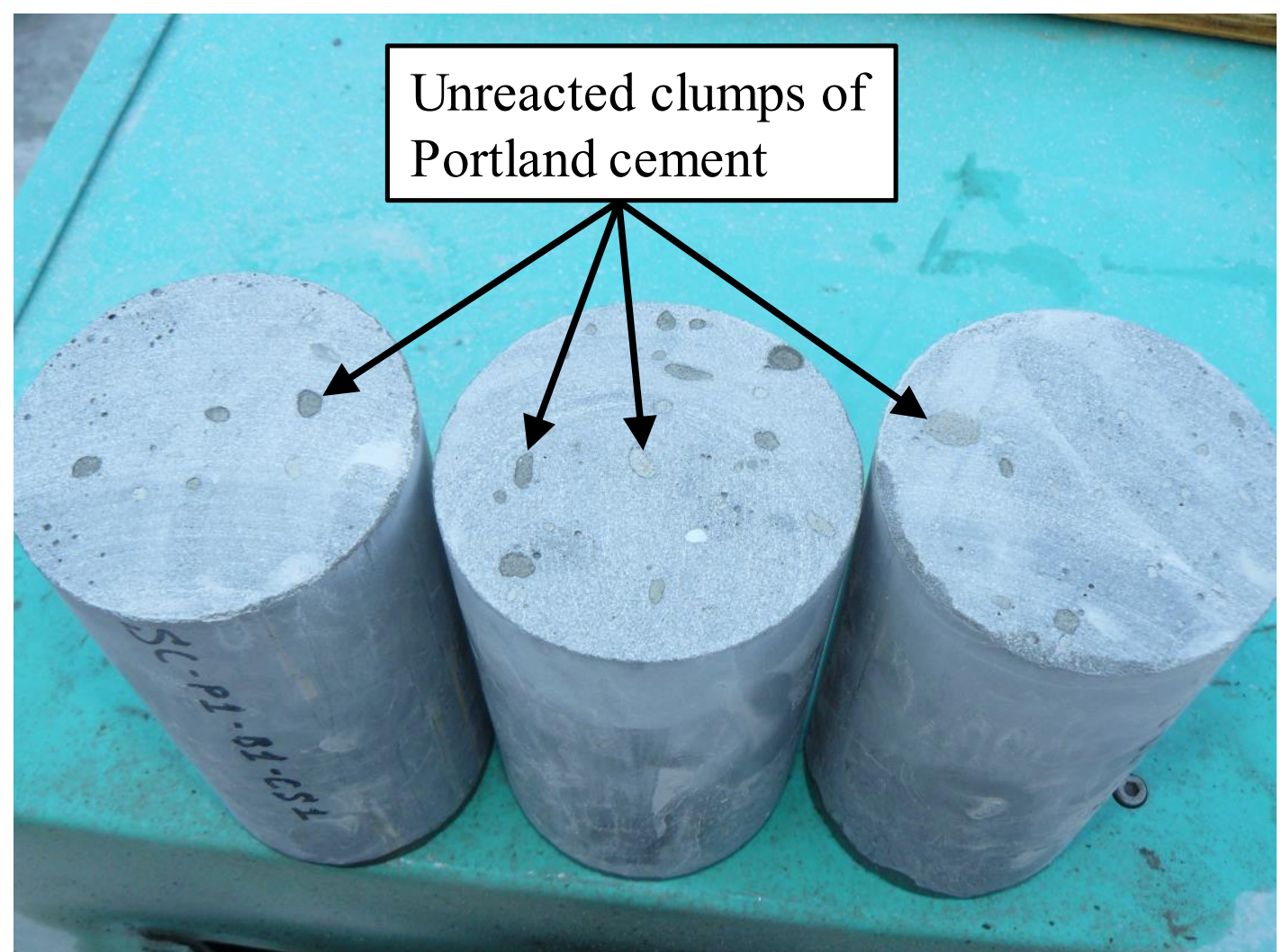

Figure 3-10 Minute unreacted clumps of Portland cement in the hardened UHPC matrix of SC-P specimen, due to the lack of experienced construction personnel and selection of improper mixing equipment 
Table 3-4 Compression Testing Results

\begin{tabular}{cccccc}
\hline Specimen & $\begin{array}{c}\text { Batch } \\
\text { Number }\end{array}$ & $\begin{array}{c}\text { Compression } \\
\text { Cylinder } \\
\text { Number }\end{array}$ & $\begin{array}{c}\text { Load } \\
\text { (kips) }\end{array}$ & $\begin{array}{c}\text { Peak } \\
\text { Strength } \\
\text { (ksi) }\end{array}$ & $\begin{array}{c}\text { Average 28-day } \\
\text { Compressive } \\
\text { Strength } \\
\text { (ksi) }\end{array}$ \\
\hline SC-P & 1 & 1 & 141.50 & 20.0 & \\
& 1 & 2 & 142.60 & 20.2 & 20.2 \\
SC-N & 1 & 3 & 143.50 & 20.3 & \\
& 2 & 1 & 163.90 & 23.2 & \\
MC-P & 2 & 2 & 148.70 & 21.1 & \\
& 2 & 3 & 149.40 & 21.2 & \\
& 3 & 1 & 133.60 & 18.9 & \\
\hline \multirow{3}{*}{ MC-N } & 5 & 1 & 135.80 & 19.2 & \\
& 6 & 1 & 132.70 & 18.8 & \\
& 7 & 1 & 131.80 & 18.7 & \\
& 9 & 1 & 130.90 & 18.5 & \\
& 10 & 1 & 129.00 & 18.3 & \\
\hline
\end{tabular}

\subsubsection{Test Setup and Instrumentation}

Figure 3-11 ( $\mathrm{a}$ and $\mathrm{b}$ ) shows the test setup with SC-P and SC-N specimens resting on two supporting steel beams with 3-in. wide neoprene pads for a clear span of 108 in. The specimens were subjected to two equal loads applied concurrently at 15 in. from the mid-span using a spreader beam over two 6 x 18 in. steel plates resting on neoprene pads, see Figure 3-12. A similar arrangement was used for Group 2 specimens as shown in Figures 3-11 (c, d, e, and f) and 3-13, however, with loading applied only on the middle box-cell to evaluate the effectiveness of transverse ribs and the contribution of adjacent box-cell components to the panel action. Single-cell specimens were loaded using a 235kip hydraulic actuator in displacement control with an average rate of $0.03 \mathrm{in} . / \mathrm{min}$. Multicell specimens were loaded using a single 60 kips hydraulic jack controlled by a single manual hydraulic pump in a test frame shown in Figure 3-14. The load was measured using 
four 2-kip load cells for single-cell specimens, and one 50-kip load cell for multi-cell specimens.

All specimens were equipped with three types of sensors: (1) string potentiometers to acquire deformation; (2) strain gauges on reinforcing bars, and (3) strain gauges on UHPC surface. The HSS bars were instrumented using 0.2 in. long strain gauges, designed for measurement of large strains up to 15\%. As shown in Figure 3-12, Bars 1 and 2 in Group 1 specimens were instrumented with two gauges at their mid- and quarter-span lengths. Bars 1 through 4 in Group 2 specimens were instrumented with only one gauge at their mid-span (see Figure 3-13). Similarly, the tension face of UHPC specimens were instrumented using $1.2 \mathrm{in.}$ long gauges with a strain limit of $2 \%$. The UHPC surface in Group 1 specimens was instrumented at two locations: mid- and quarter-span, whereas Group 2 specimens were instrumented at four locations: mid-span of each box-cell as well as mid-span of the transverse rib; at each location, two strain gauges were attached to improve reliability. Furthermore, 12 in. long string potentiometers were installed to monitor deflections, at three locations for single-cell specimens (mid- and quarter-spans), and six locations for multi-cell specimens (mid-span of each box-cell and quarter-spans of center box-cell and one of the two exterior box-cells). A data acquisition system was used with a sampling frequency of $1 \mathrm{~Hz}$. Loading was stopped after capturing, on average, $15 \%$ drop after the peak load. 


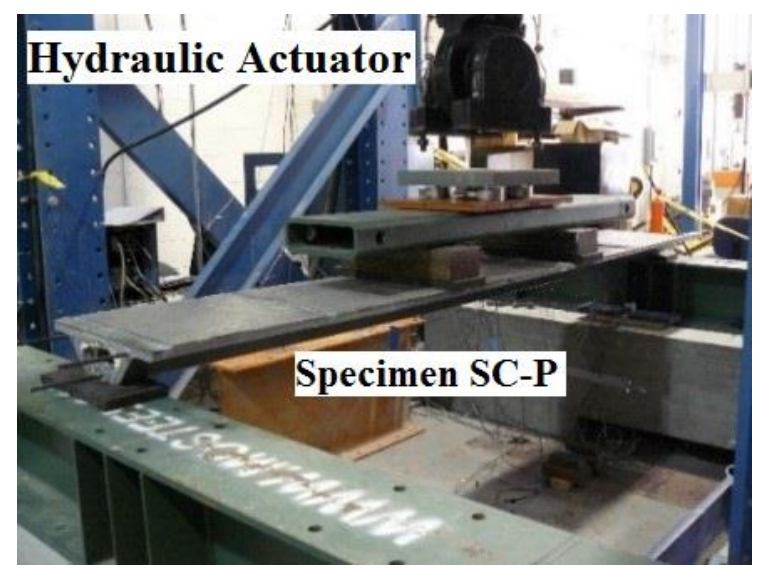

(a)

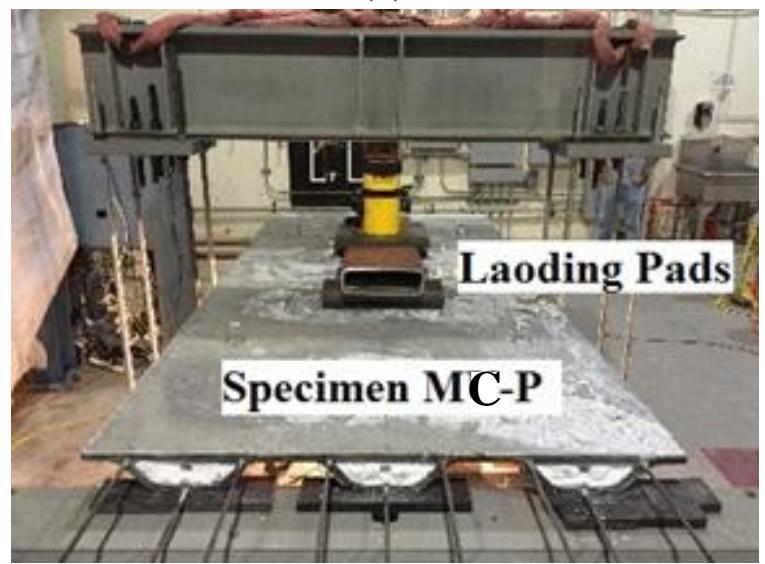

(c)

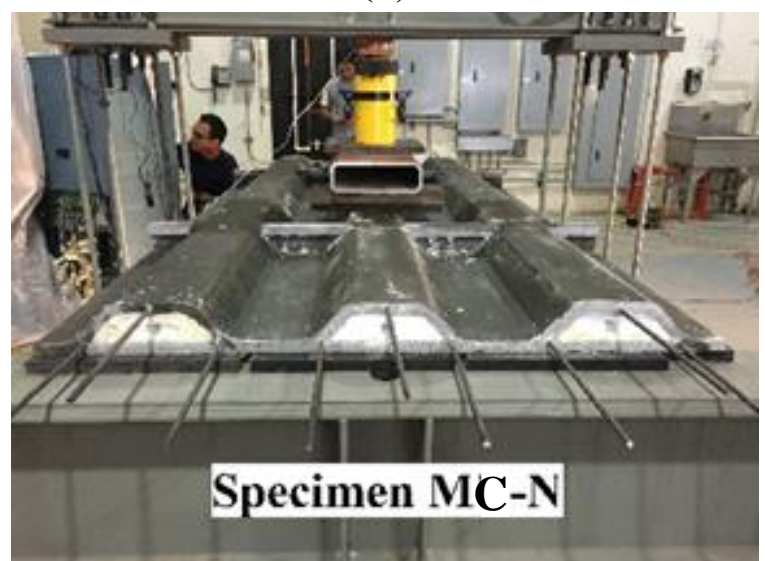

(e)

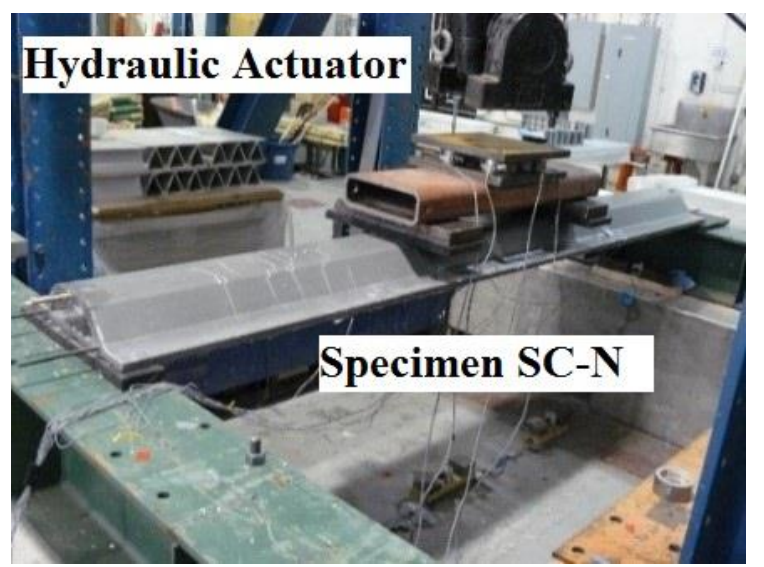

(b)

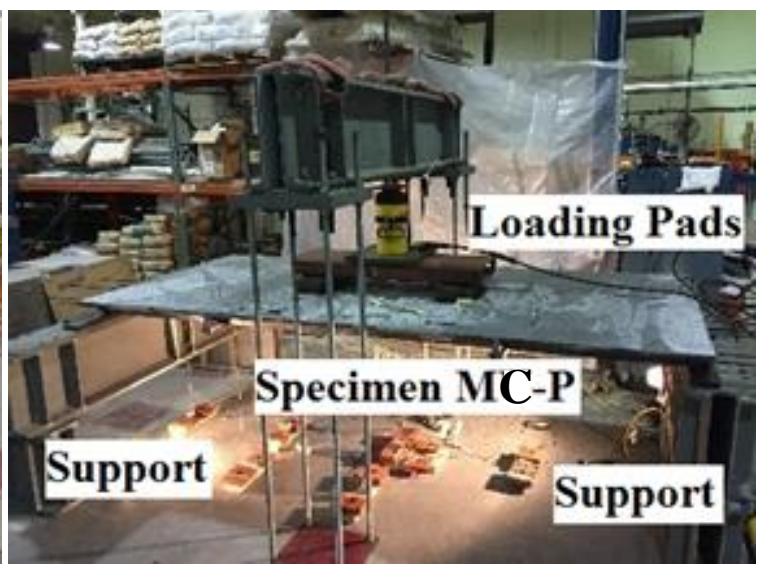

(d)

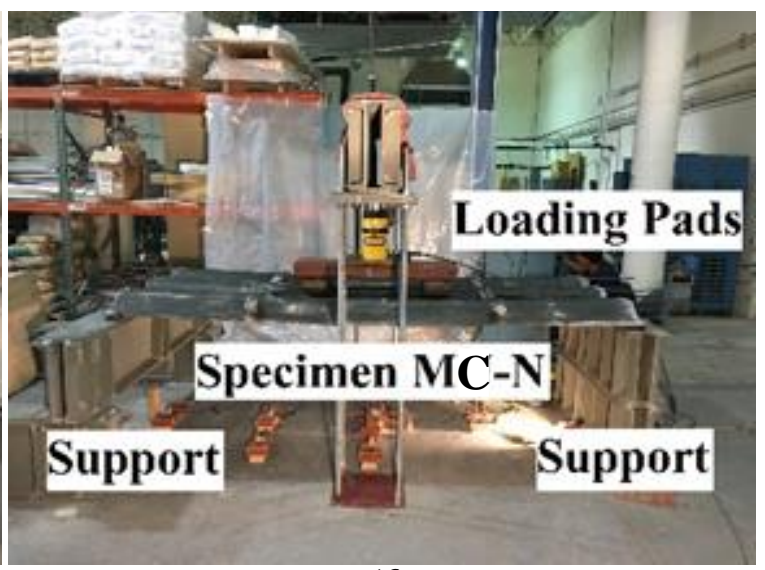

(f)

Figure 3-11 Flexure test setup: (a) Specimen SC-P; (b) Specimen SC-N; (c and d) Specimen MC$\mathrm{P}$; (e and f) Specimen MC-N 


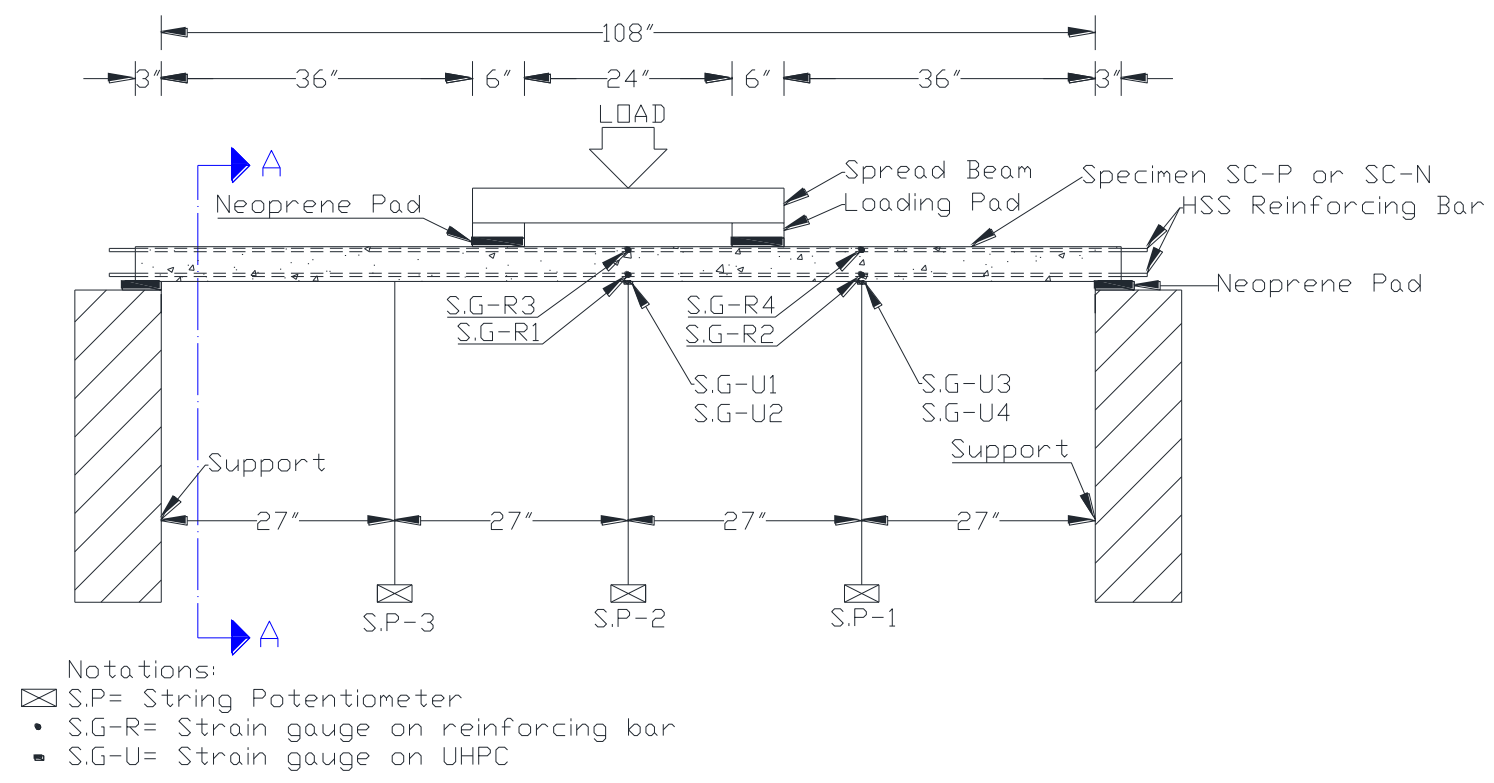

(a)

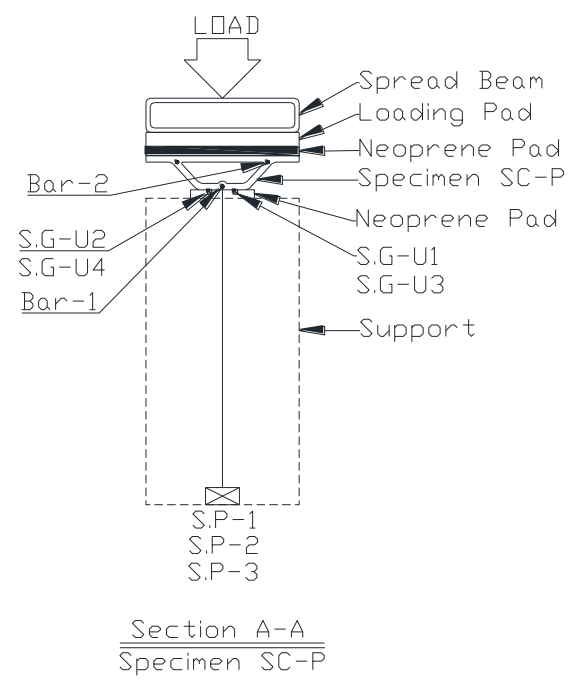

(b)

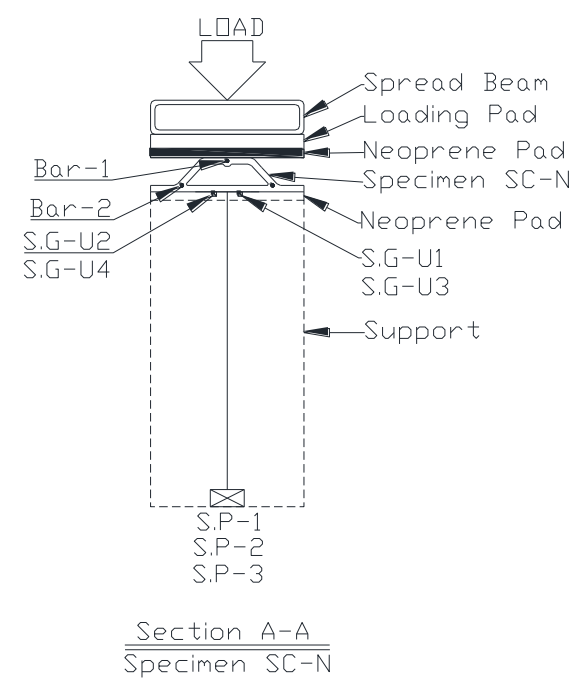

(c)

Figure 3-12 Test setup and instrumentation details of Single-cell specimens: (a) Side view; (b) Specimen SC-P; (c) Specimen SC-N 


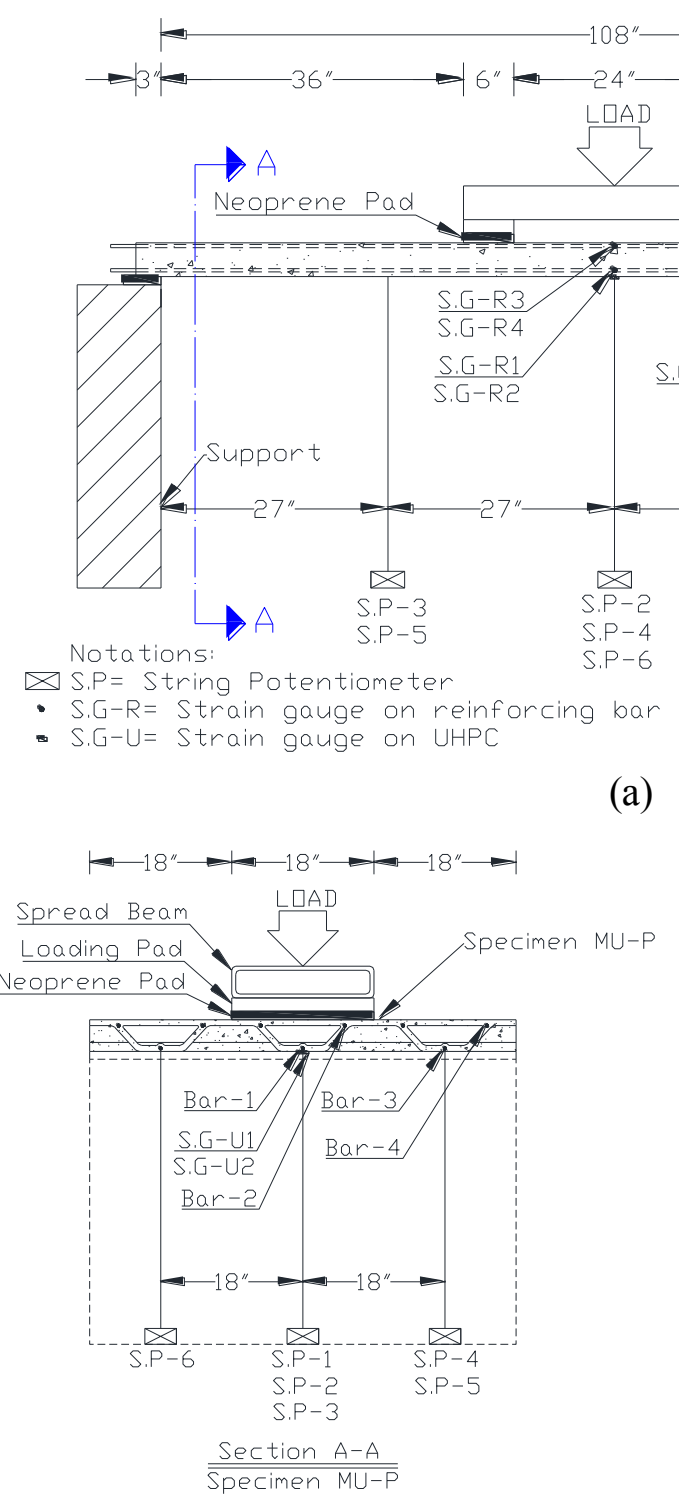

(b)

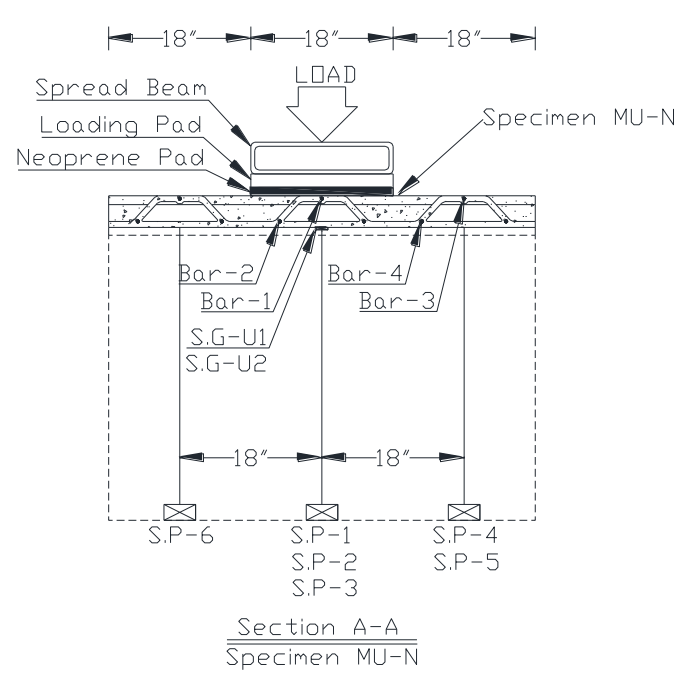

(c)

Figure 3-13 Test setup and instrumentation details of Multi-cell specimens: (a) Side view; (b) Specimen MC-P; (c) Specimen MC-N 


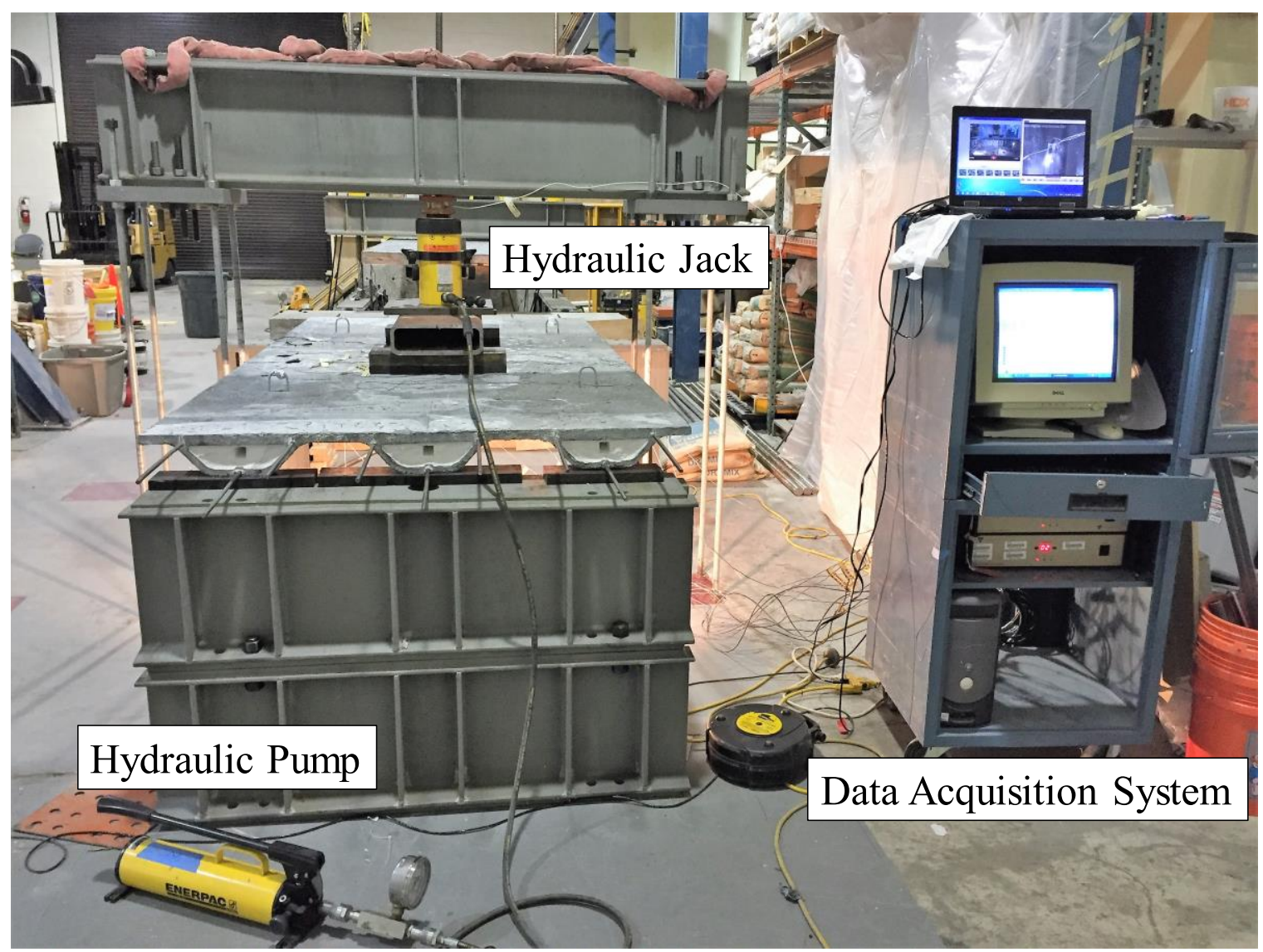

Figure 3-14 Loading system utilized for testing of Multi-cell specimens

\subsubsection{Test Results and Discussions}

Table 3-5 summarizes test results for the two groups of specimens. Figure 3-15 shows the crack patterns and failure modes of the specimens. Flexural cracks in single-cell specimens appeared initially at mid-span around $75 \%$ of the peak load in positive bending and $62 \%$ in negative bending. While developing secondary cracks between the loading plates, the main cracks propagated through the web and eventually reached the flange at the peak load. Similarly, flexural cracks in multi-cell specimens developed at the mid-span and propagated along the width until all three box-cells were fully cracked. Multi-cell specimens were more resilient to cracking as compared to single-cell specimens, as their first crack appeared at around $80 \%$ and $87 \%$ of their peak loads under positive and negative 
bending, respectively. Due primarily to the fiber pullout mechanism of UHPC, failure in both groups of specimens was not sudden or abrupt, but rather ductile. Multi-cell specimens showed a higher ductility, as expected. Despite lack of any shear reinforcement, no shear crack was observed in any specimen due to the high shear span to depth ratio of over 10:1.

Table 3-5 Summary of Flexural Test Results

\begin{tabular}{lcccc}
\hline \multirow{2}{*}{ Item } & \multicolumn{2}{c}{ Group 1 (Single-cell) } & \multicolumn{2}{c}{ Group 2 (Multi-cell) } \\
\cline { 2 - 5 } & SC-P & SC-N & MC-P & MC-N \\
\cline { 2 - 5 } Yield Load* (kips) & 3.27 & 3.42 & $7.14^{* *}$ & $12.3^{* *}$ \\
Failure Load (kips) & 4.35 & 6.48 & 15.24 & 20.93 \\
Ductility Ratio & 1.33 & 1.89 & $2.13^{* *}$ & $1.70^{* *}$ \\
Mid-span Deflection (in.) & 1.3 & 3.7 & 4.9 & 3.9 \\
$\begin{array}{l}\text { Demand Moment (kip-ft) } \\
\text { Moment Capacity (kip-ft) }\end{array}$ & 5.79 & 8.72 & 17.4 & 26.2 \\
$\begin{array}{l}\text { Reduced Moment } \\
\text { Capacity }\end{array}$ & 7.07 & 10.5 & 24.8 & 34.0 \\
Capacity/Demand Ratio & 6.36 & 9.48 & 22.3 & 30.6 \\
\hline At & 1.10 & 1.09 & 1.28 & 1.17 \\
\hline
\end{tabular}

*At $0.4 \%$ strain;

**Average value;

***Calculated based on the strength reduction factor of 0.9 from ACI 318 (2008). 

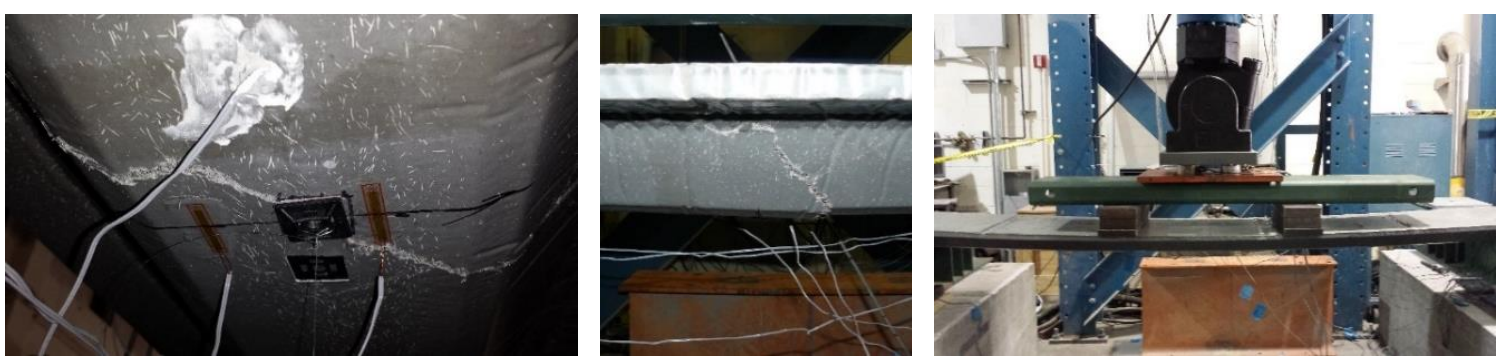

(a)
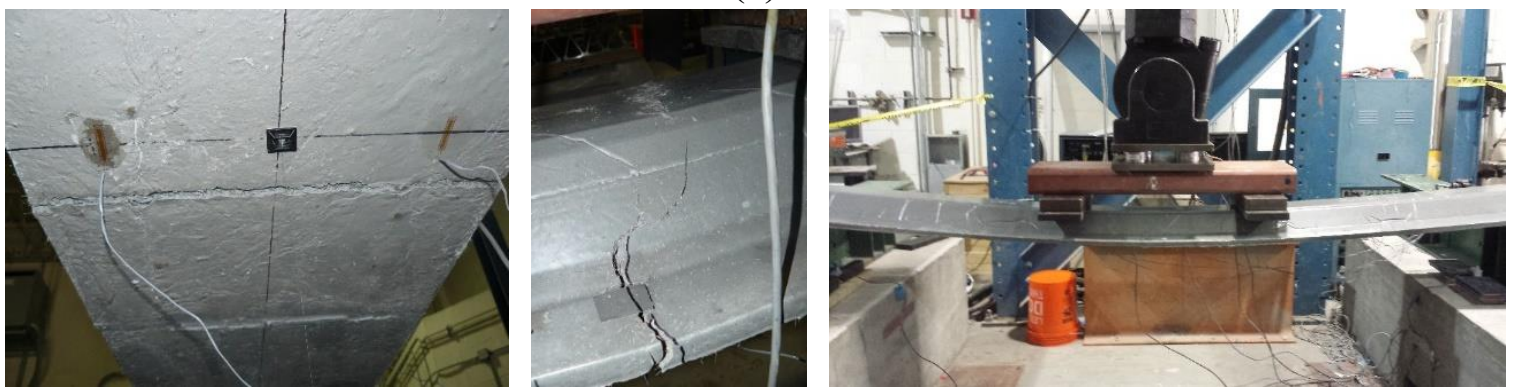

(b)
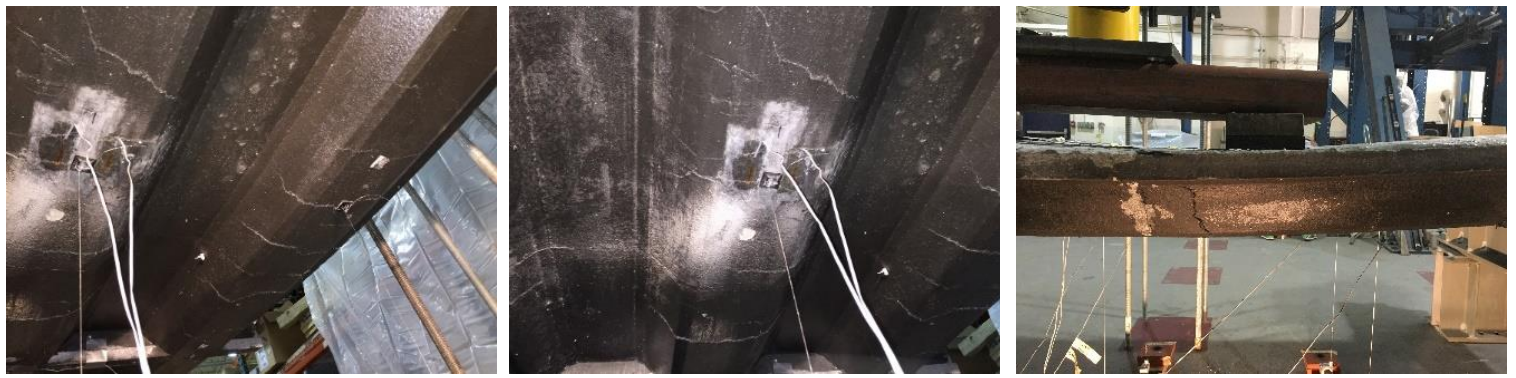

(c)
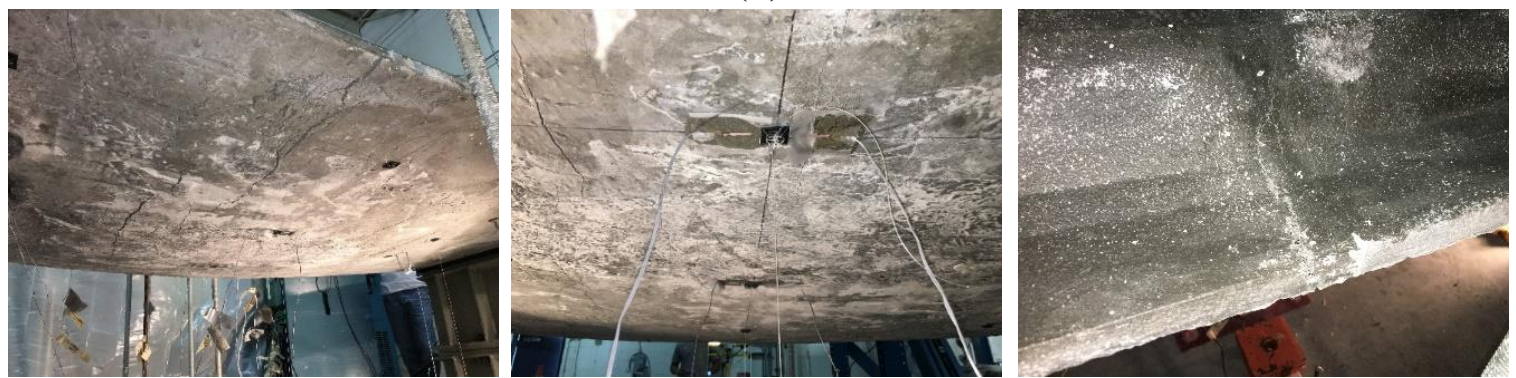

(d)

Figure 3-15 Flexural test modes of failure; (a) SC-P; (b) SC-N; (c) MC-P; (d) MC-N

Figures 3-16 and 3-17 show the load-deflection responses of single-cell and multicell specimens, respectively, at their mid- and quarter-span locations. The upper half of each graph represents positive bending; while the lower half shows negative bending. SC$\mathrm{P}$ under positive pressure failed at a high load of $4.35 \mathrm{kips}$ and a maximum deflection of 
1.27 in. at mid-span; whereas under negative pressure, it deformed $3.67 \mathrm{in}$. at peak load of 6.48 kips. Multi-cell specimens failed at 15.2 kips and 20.9 kips loads in positive and negative bending, respectively, with deflections of 4.94 in. and 3.89 in., respectively. A symmetric response is noted along the span, as evident from the quarter-spans response curves. Test results also show almost an identical response for multi-cell specimens under both bending configurations for all three box-cell components. Again, response curves are clearly ductile.

Figures 3-18 and 3-19 shows load-strain responses of HSS bars in single-cell and multi-cell specimens, respectively. In all cases, HSS bars at mid-span had clearly yielded, and the responses were ductile. This point is further reinforced by the sizeable ductility ratios noted in Table 3-5. The maximum strain in HSS bars was 3.2\% for single-cell specimens in negative bending, and $3.4 \%$ for multi-cell specimens in positive bending. However, in both cases, the maximum strains were still considerably lower than the rupture strain of $4 \%$. In the case of Specimen SC-P, all but one mid-span strain gauge failed before reaching the peak load, as marked by solid end caps in Figure 3-18. 


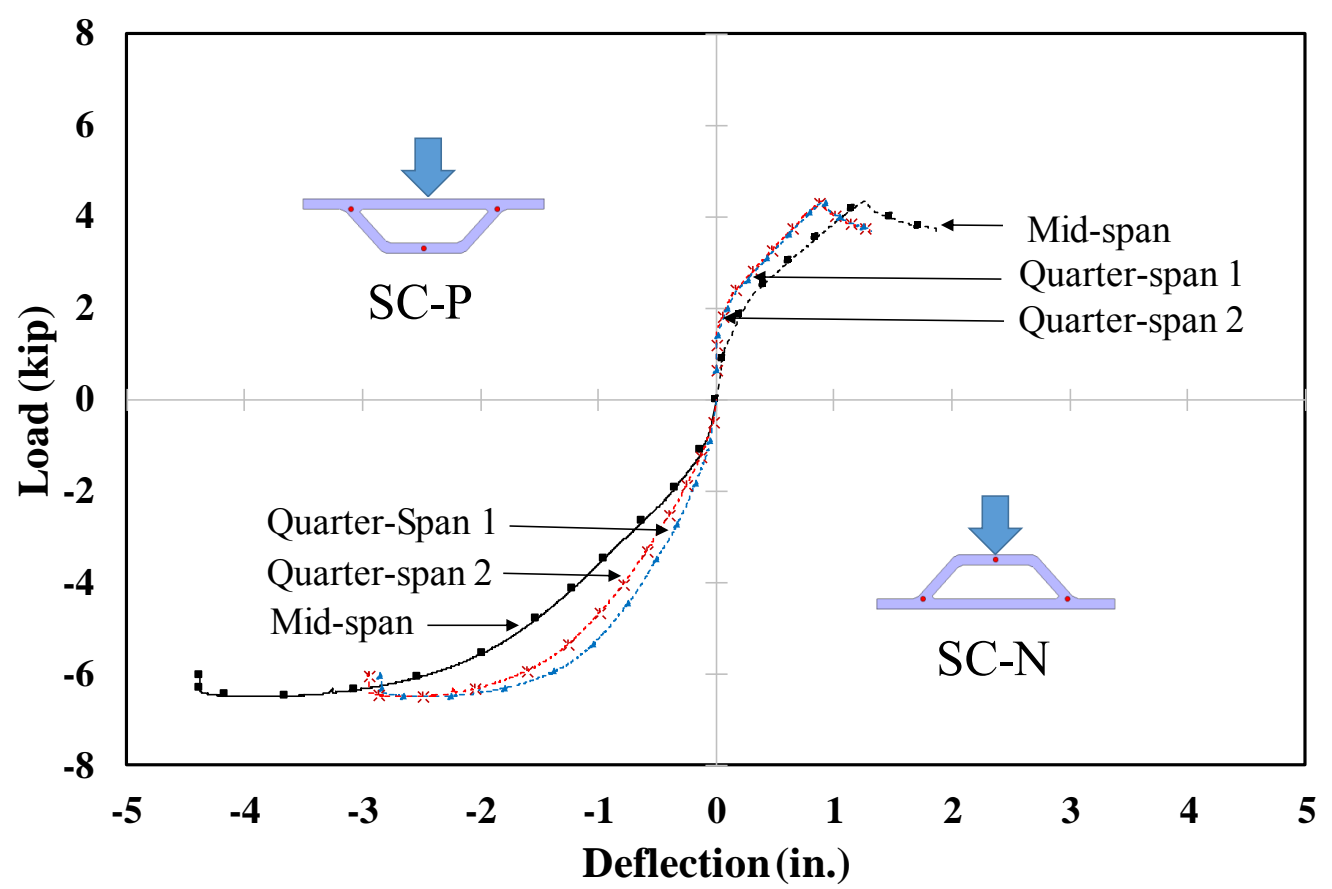

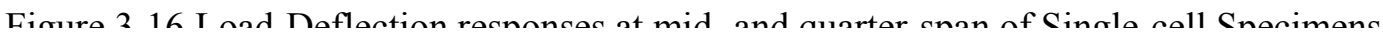

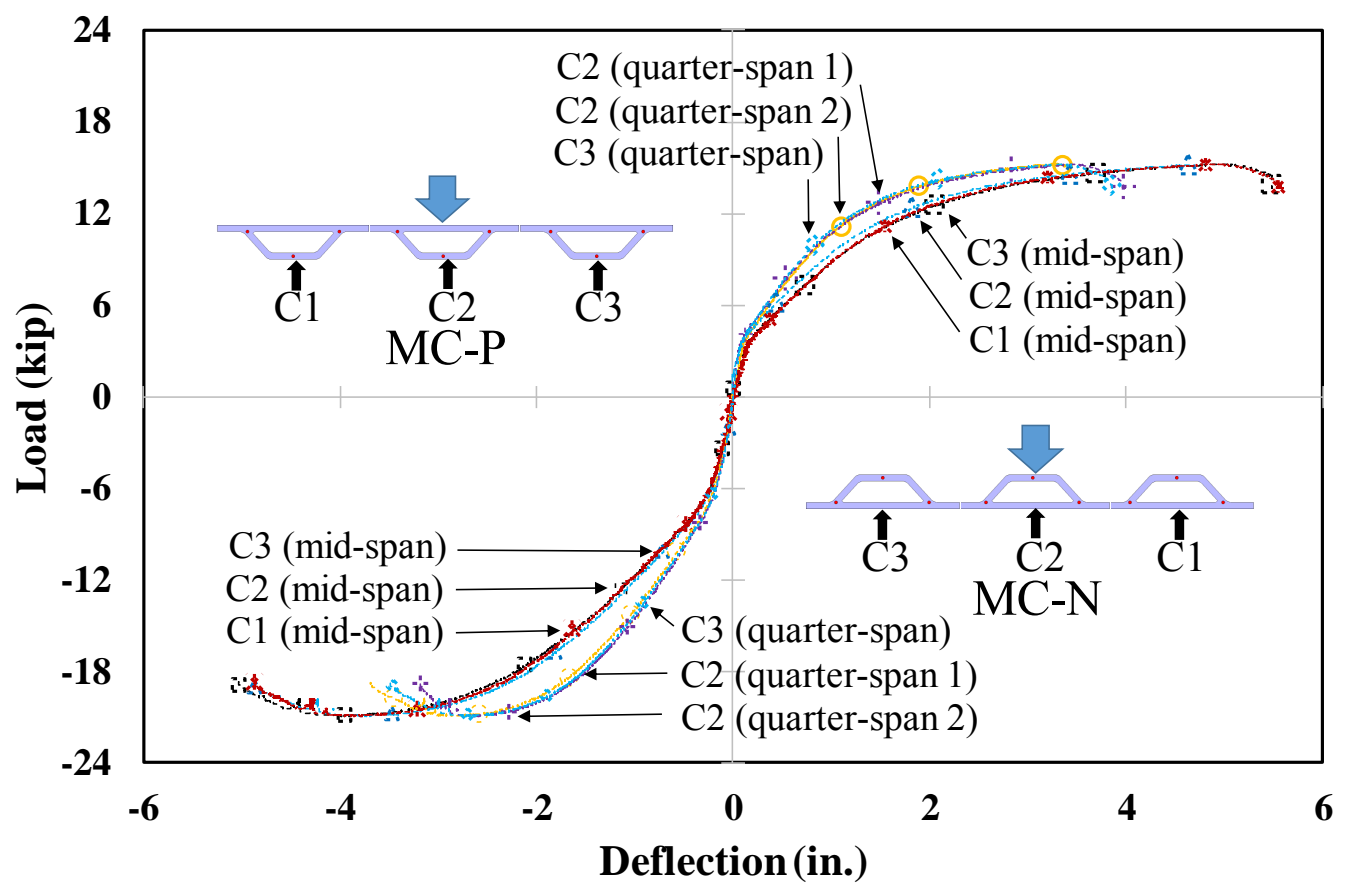

Figure 3-17 Load-Deflection responses at mid- and quarter-span of Multi-cell Specimens 


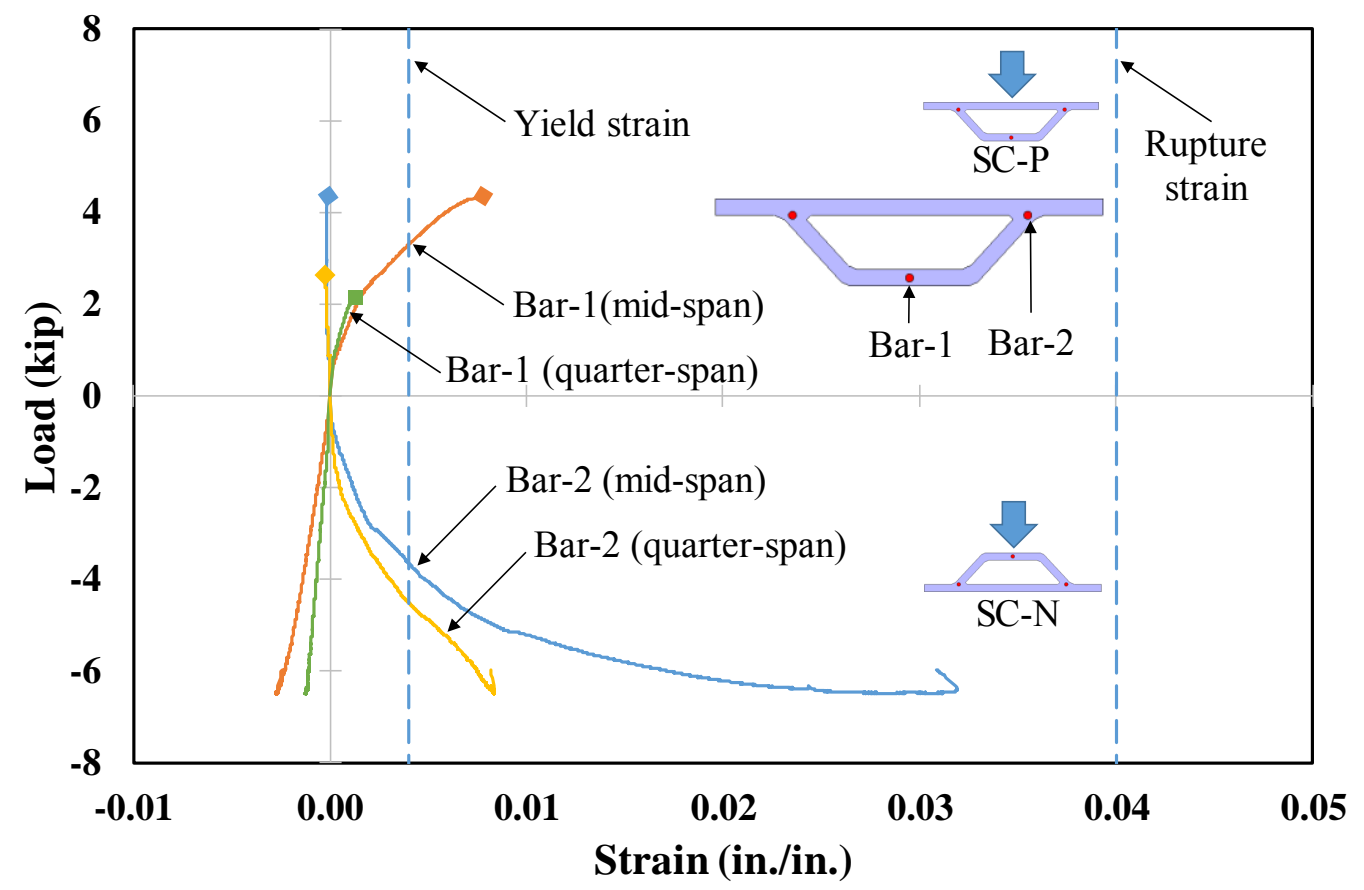

Figure 3-18 Load-Strain responses of HSS reinforcement of Single-cell specimens

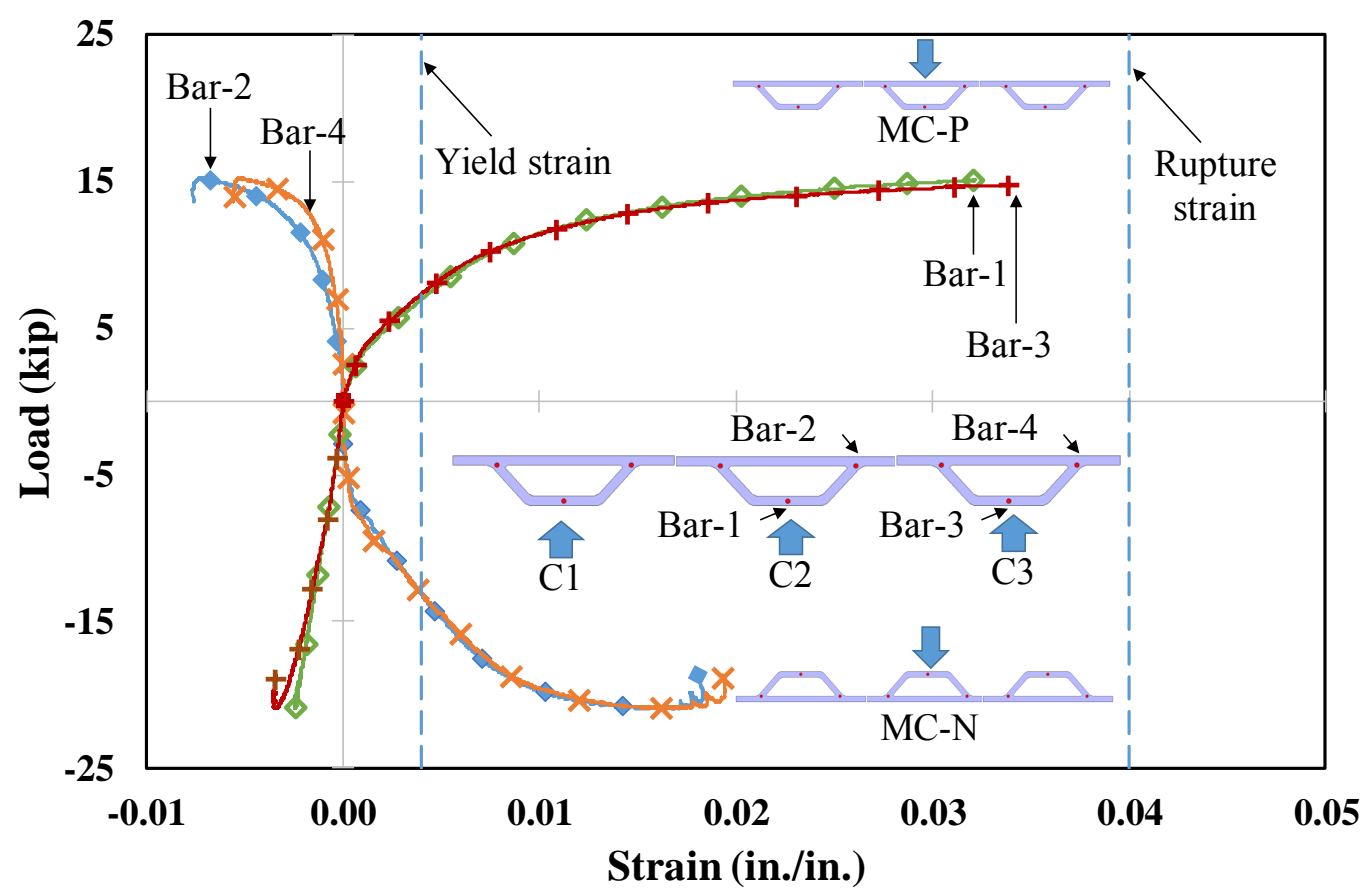

Figure 3-19 Load-Strain responses of HSS reinforcement of Multi-cell specimens 
Figure 3-20 shows the load-strain responses of UHPC on the tension surface of single-cell specimens at mid- and quarter-spans. A bilinear response is noted in both bending configurations with an early cracking at about $0.05 \%$ strain and a strong postcracking response up to the maximum tensile strain of $0.7 \%$ at mid-span, as expected from UHPC. Unfortunately, strain gauges in multi-cell specimens did not record data, except for the one on the transverse rib, which showed very low strains, implying a strong panel action and 1ark of anv 1ataral handing

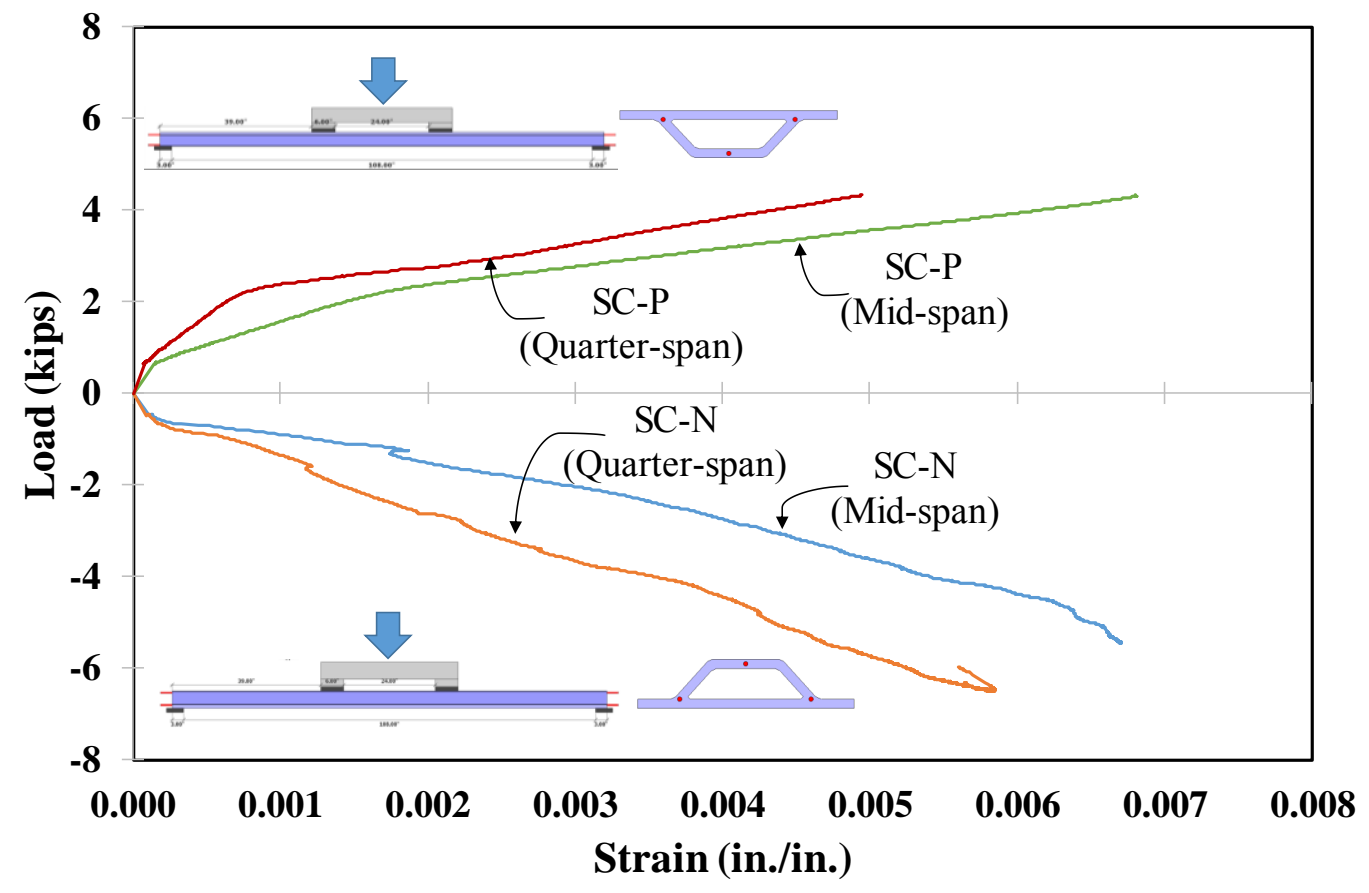

Figure 3-20 Load-Tensile strain responses of UHPC in Single-cell specimens

\subsubsection{Panel Action}

The deflection and strain responses of multi-cell specimens discussed earlier in Figures 3-17 and 3-19 clearly indicate that all three box-cells participated equally in carrying the loads even though applied only on the central box-cell. This suggests a distribution factor of 0.33 , based on either deflections or strains in the adjacent box-cells 
relative to those in the central box-cell. This is further confirmed by the ratio of the failure loads in single-cell and multi-cell specimens, which amounts to 0.29 in positive bending and 0.31 in negative bending. Additional confirmation stems from the very low strains on the UHPC surface of transverse ribs in tension, as noted earlier, and despite the fact that the ribs do not go through the box cells. As a result, the equal distribution factor of 0.33 confirms the strong panel action that exists in multi-cell specimens.

Given that multi-cell specimens consisted of three box-cell components; it was expected that multi-cell specimens would reach a high range of an ultimate load of three times the capacity of the individual single-cell specimens -- by the assumption of uniform load distribution (equal load distribution factor). As a result, the failure loads for multi-cell specimens were $16.5 \%$ and $7.5 \%$ higher than triple the failure loads of corresponding single-cell specimen in positive and negative bending, respectively, although their average 28-day compressive strength was slightly less than single-cell specimens. Moreover, multicell specimens showed a considerably higher ductility relative to single-cell specimens. Therefore, one may conclude the effectiveness of transverse ribs, as they help integrate the box-cells and distribute the imposed loads uniformly across the width of the specimen. This is despite the facts that (1) no transverse reinforcement was used in the design, and (2) transverse ribs did not cross the hollow box-cell components.

\subsubsection{Flexural Strength}

Although laboratory constraints limited the lengths of test specimens to $9 \mathrm{ft}$, flexural strengths of multi-cell specimens compare favorably with demand loads for the 20 -ft target span in both positive and negative bending configurations, even with the 
conservative assumption of simply supported panels (Sayyafi et al. 2017; Sayyafi 2016). Table 3-5 lists the expected demand moments, as compared to moment capacities from the experiments and the reduced moment capacities based on the strength reduction factors of ACI 318 (2008). The capacity/demand ratios are quite close in the two bending configurations, implying that the section is optimal in its design for positive and negative bending. In addition, multi-cell specimens exhibited higher capacity/demand, in part due to their transverse ribs. Figure 3-21 shows the moment-deflection responses of multi-cell specimens along with the ultimate demand moments for the $20-\mathrm{ft}$ span. It is clear that the proposed roof system successfully meets the demand loads in both positive and negative bending configurations.

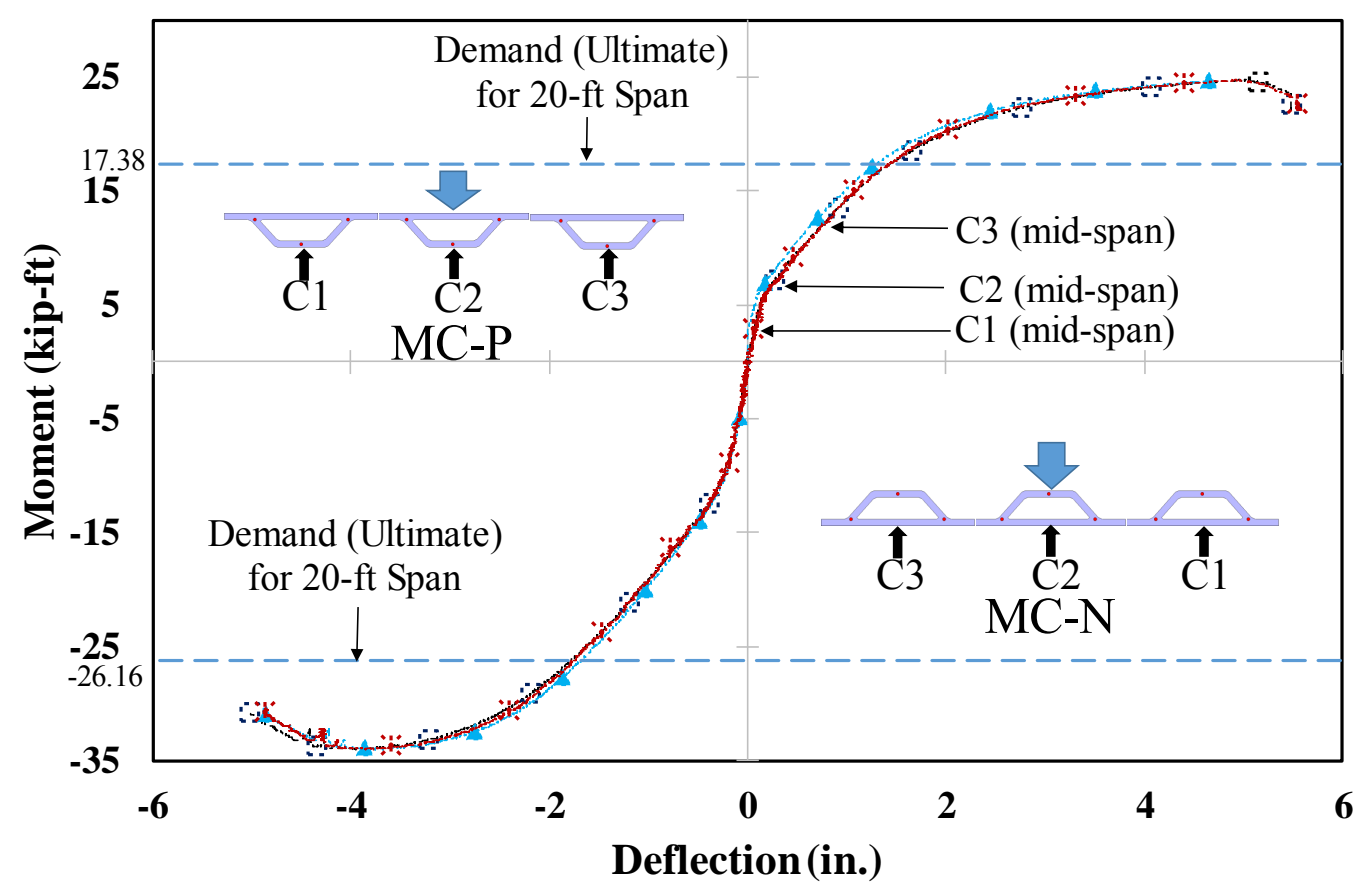

Figure 3-21 Moment-Deflection responses at mid-span of Multi-cell specimens 


\subsection{Shear Strength}

\subsubsection{Experimental Work}

In order to investigate the shear strength, one shear sample was prepared and tested. Figure 3-23 and 3-24 illustrate the geometric details of the sample. It is a short-length single-cell specimen (24 in.) tested under three-point loading. It was tested wide-flange down, due to the fact that flexural test demonstrated that the section carried more load in negative loading. The tests measured the shear strength and deflection. The specimen named "SC-S" in which "SC" stands for Single-cell and "S" stands for shear.

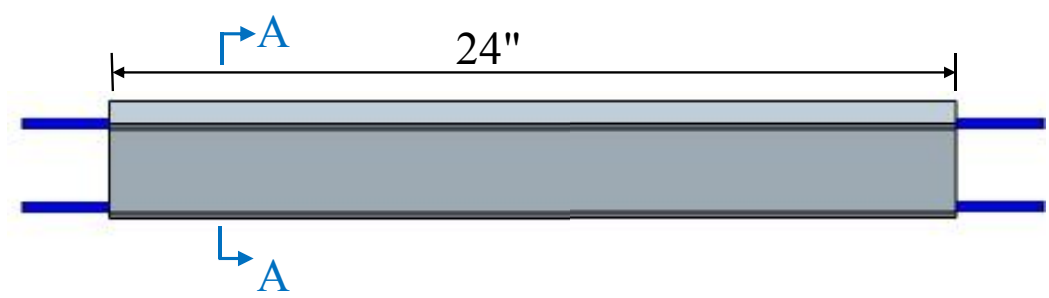

(a)

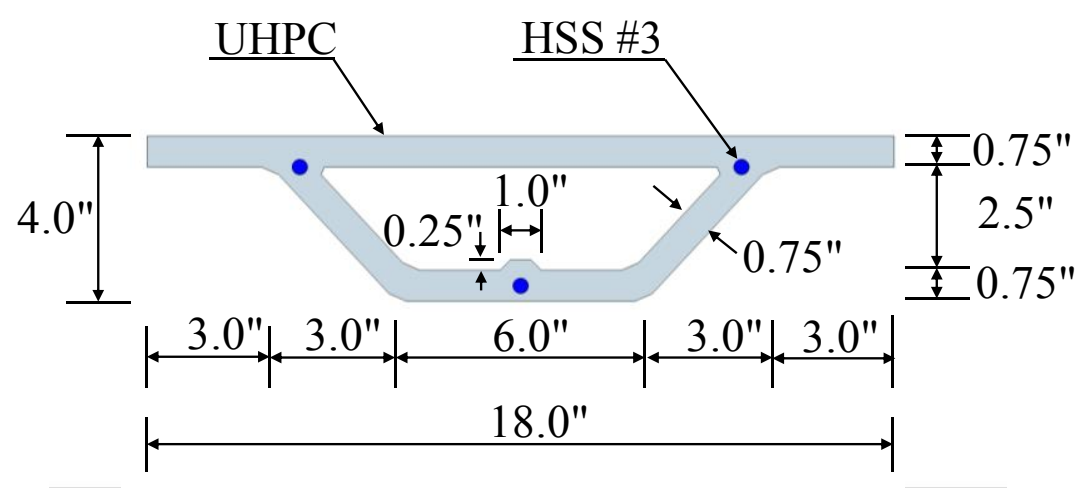

$\underline{\text { Section A-A }}$

(b)

Figure 3-22 Geometric details of shear specimen (SC-S) 

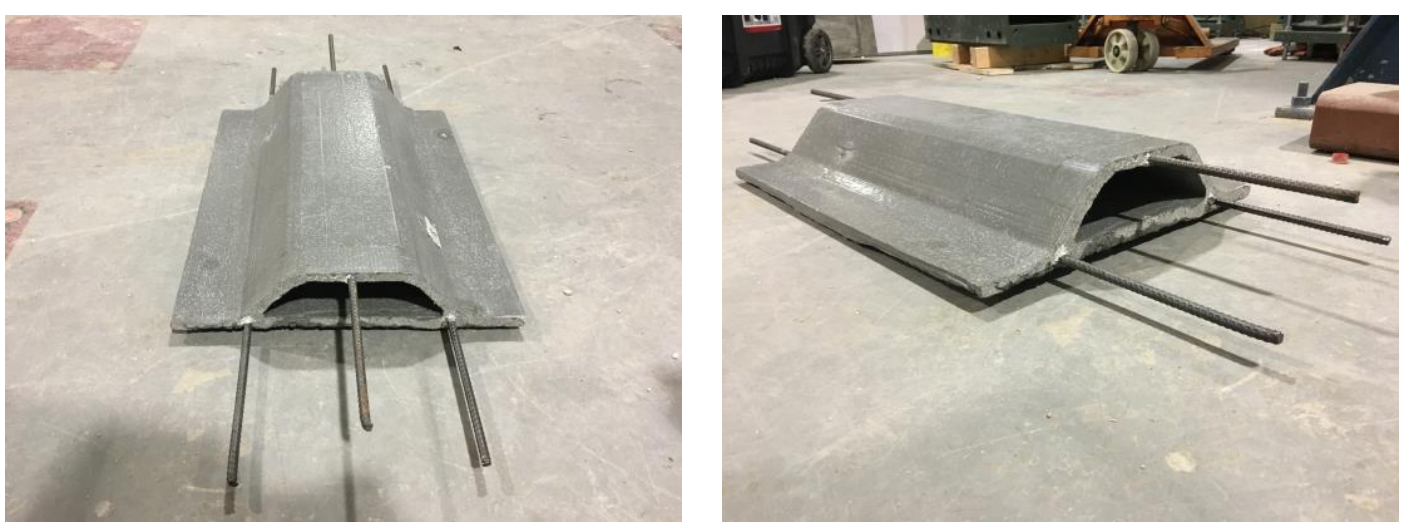

Figure 3-23 Shear specimen (SC-S)

\subsubsection{Test Setup and Instrumentation}

Figure 3-24 shows the test setup with the shear specimen SC-S resting on two supporting concrete blocks with 3-in. wide neoprene pads for a clear span of 18 in., a spanto-depth ratio of $4.5: 1$. The specimen was subjected to a load applied at the mid-span using a 4-in. wide steel plate resting on neoprene pad, see Figure 3-25. The specimen was loaded using a single 30-kip hydraulic jack controlled by a single manual hydraulic pump in a test frame shown in Figure 3-25. The load was measured using 50-kip load cell. Mid-span deflection was measured using a string potentiometer, recorded by a data acquisition system. The test ended when sample dropped $10 \%$ of maximum load. Figure 3-25 shows specimens under the testing load. 


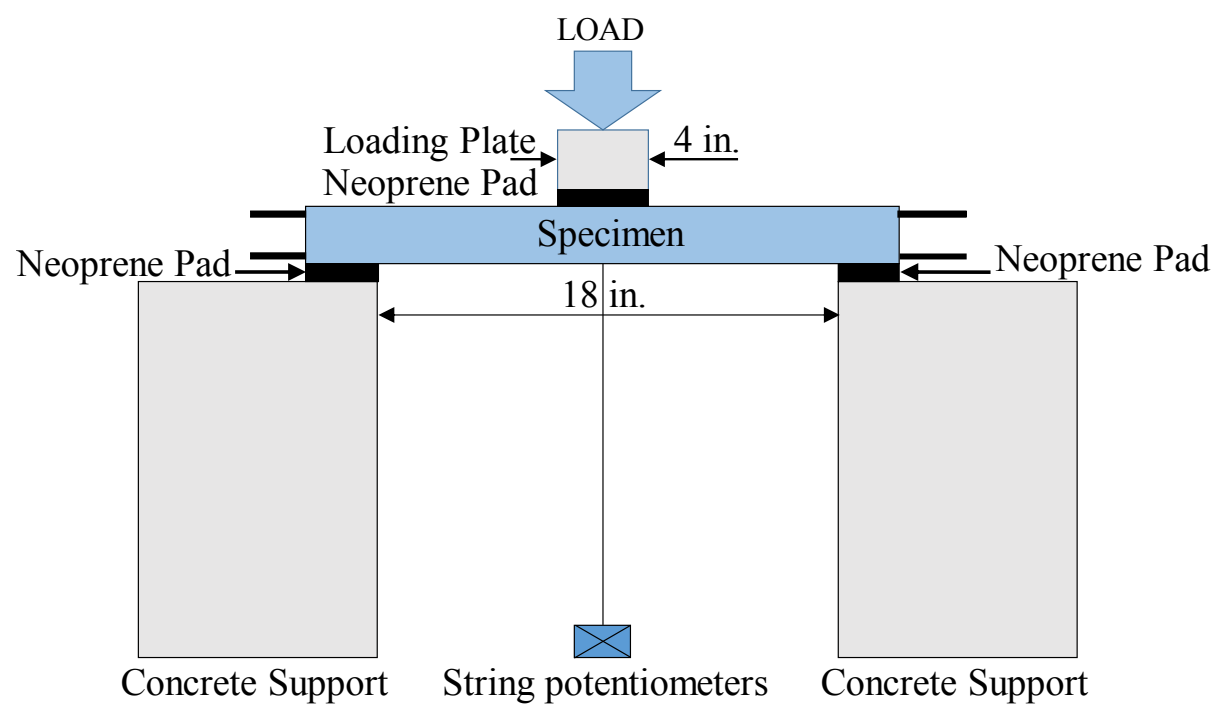

Figure 3-24 Test setup and instrumentation with shear specimen SC-S
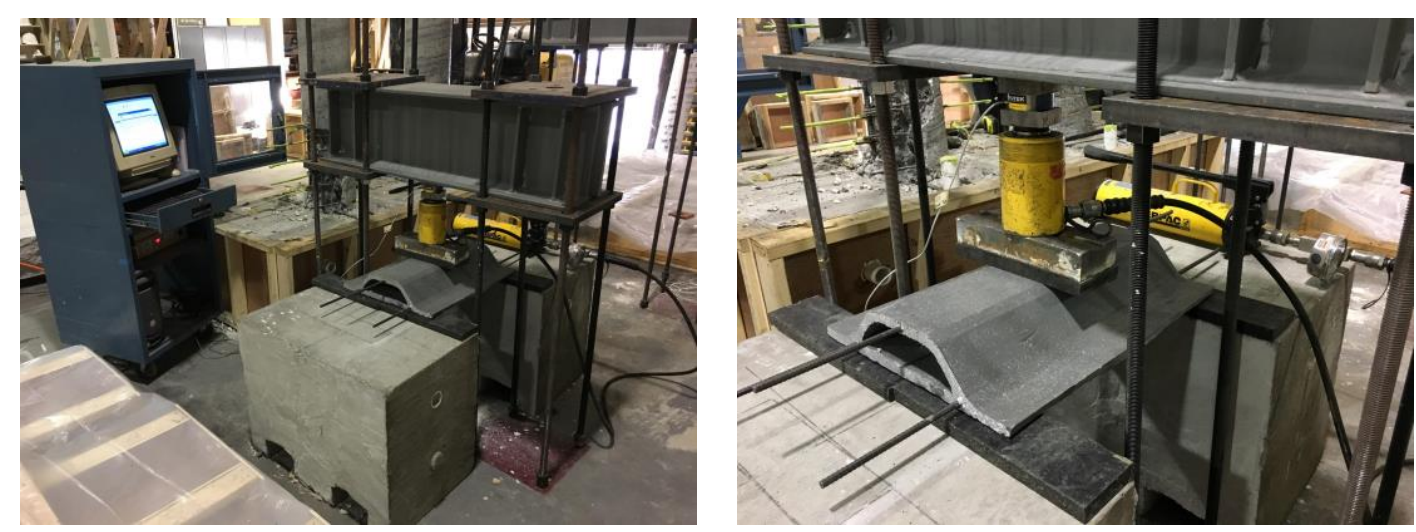

Figure 3-25 Shear specimen SC-S under testing load

\subsubsection{Test Results and Discussions}

Figure 3-26 shows the crack patterns and failure modes of the specimen. Shear cracks appeared initially around $60 \%$ of the peak load. Due primarily to the fiber pullout mechanism of UHPC, failure was not sudden or abrupt, but rather ductile. Despite lack of any shear reinforcement, the thin-walled box-cell demonstrated significant shear resistant. However, no significant visible shear crack was observed, attributed to the high shear strength of UHPC due to the steel fibers. Table 3-6 summarizes test results for the shear 
specimen. Figure 3-27 shows the load-deflection responses of SC-S specimen at its midspan. Specimen failed at a high load of 15.6 kips and a maximum deflection of 0.43 in. at mid-span. Response curve clearly shows a ductile behavior.

Table 3-6 Summary of Shear Test Results

\begin{tabular}{lc}
\hline Specimen & SC-S \\
Failure Load (kips) & 15.6 \\
Maximum Deflection (in.) & 0.43 \\
Shear Capacity (kips) & 7.8 \\
Reduced Shear Capacity* (kips) & 5.9 \\
Demand Shear** (kips) & 3.48 \\
Capacity/Demand Ratio & 1.7
\end{tabular}

*Reduced by application of a strength reduction factor of 0.75 for shear; as specified by the ACI Code (ACI 318), for design purposes.

**Calculated based on the design load of $116.3 \mathrm{lb} / \mathrm{ft}^{2}$ (upward pressure resulting from Load Combination 3, see Table 2-4) on the 20-ft. roof span, multiplied by 2 according to the ACI code (ACI 318, section 11.5.5) for shear design of reinforced concrete with no shear reinforcements provided.

Specimens failed at 15.6 kips loading, demonstrating 7.8 kips shear strength - half of the failure load. A reduction factor of 0.75 was applied - as specified by the ACI Code (ACI 318) - for designing purpose, which reduces the shear strength to 5.9 kips. The demand shear strength of 3.48 kips was calculated based on the design load of $116.3 \mathrm{lb} / \mathrm{ft} 2$ (upward pressure resulting from Load Combination 3, see Table 2-4) on the 20-ft. roof span, multiplied by number two -- according to the ACI code (ACI 318, section 11.5.5) for shear design of reinforced concrete with no shear reinforcements provided. As a result, test specimen exhibited reduced shear strength of 5.9 kips significantly exceeding the demand strength of 3.48 kips, with capacity/demand ratio of 1.7 .

The shear strength of 7.8 kips was only attributed to the UHPC, due to the fact that no shear reinforcement was provided. Shear specimen demonstrated a clearly ductile 
behavior, due primarily to the steel fibers acting as reinforcement in UHPC at micro level. One may conclude that the ACI approach for designing reinforced concrete with no shear reinforcement needs more investigation for UHPC application. Steel fibers act as reinforcements - flexural and shear -- in UHPC, therefore, safety factor of 2 for not-shearreinforced UHPCs is very conservative. This approach may be true for conventional concrete that show abrupt and sudden shear failure, but not applicable for UHPC. However, shear test demonstrated that the proposed thin-walled UHPC section offers high shear resistance, exceeding the demand shear capacity even calculated with the current ACI criterion.

As a result, shear test results demonstrated that the proposed thin-walled box-cell section offers high shear strength with shear capacity demand ratio of 1.7 , despite the lack of shear reinforcements. This resistance is only attributed to the thin-walled UHPC with no shear reinforcement provided. Therefore, it is concluded that the thin-walled section utilized successfully withstands shear forces at 20-foot span with no shear reinforcing bars or stirrups required.

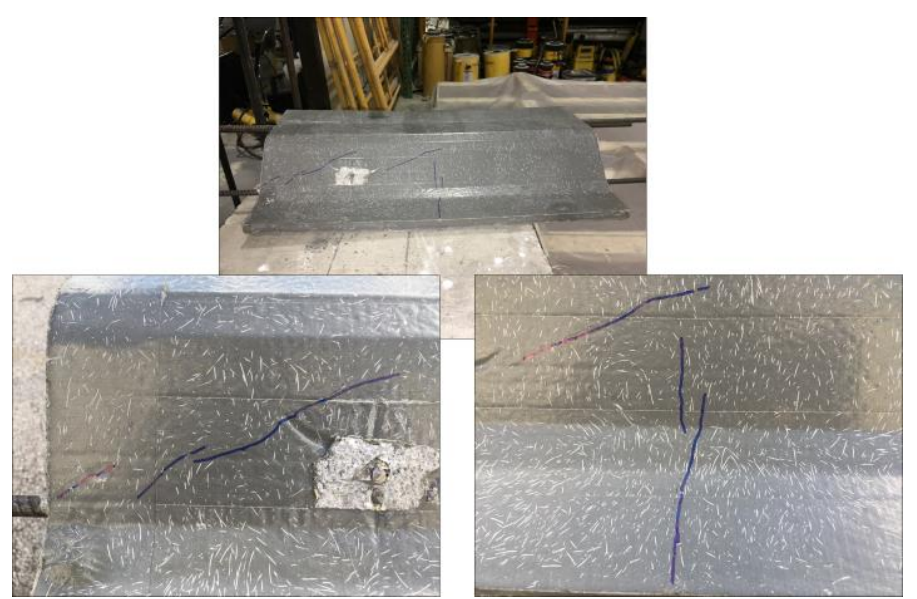

Figure 3-26 Shear test mode of failure and crack patterns, specimen SC-S 


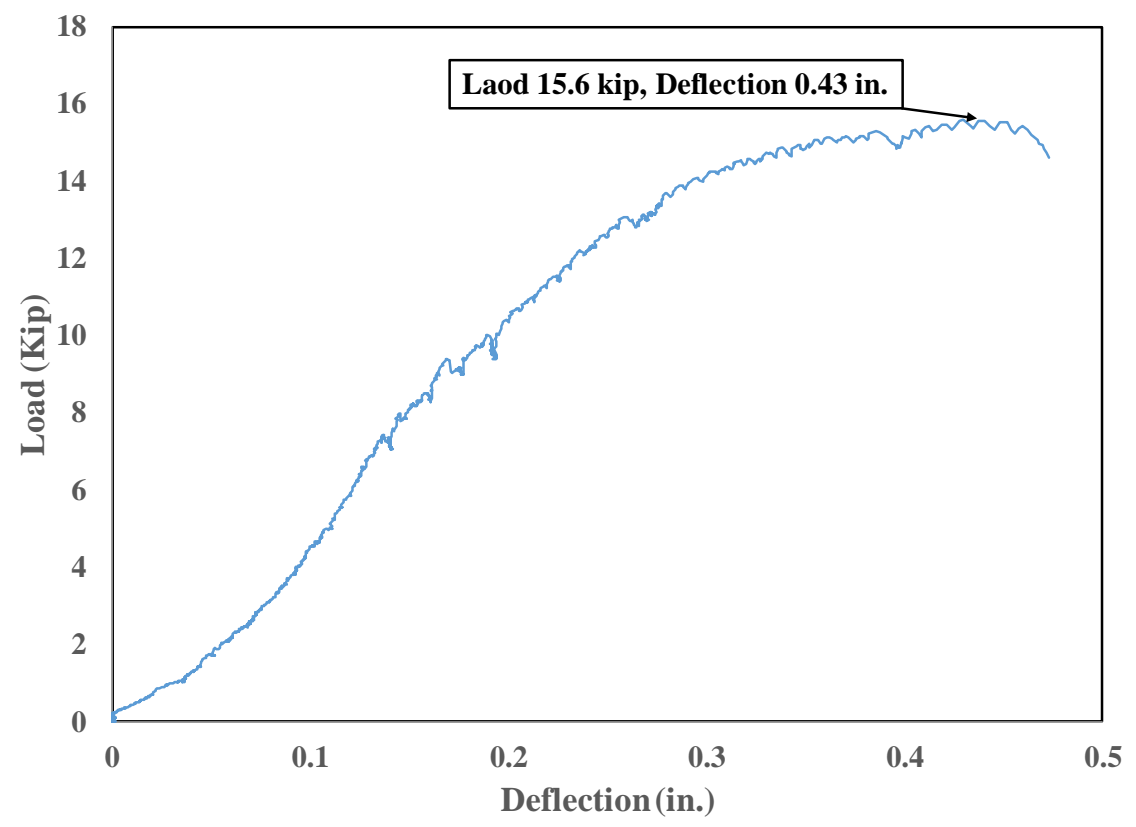

Figure 3-27 Load-Deflection response of shear test

\subsection{Conclusions}

In this chapter, the ultimate strength of the proposed roof system - including flexural and shear strength -- was investigated through the experimental work on laboratory specimens. Experimental results clearly demonstrated that the proposed roof system successfully meets the demand strengths and can withstand wind pressures for up to 209 mph wind velocity and up to a target span of $6.1 \mathrm{~m}(20 \mathrm{ft})$ with a span-to-depth ratio of 60:1. The following conclusions may be drawn from this study:

- Flexural specimens showed a ductile flexural behavior with HSS bars yielding at mid-span.

- Despite lack of any shear reinforcement, no shear crack was observed in any flexural tests. 
- Multi-cell specimens showed an improved flexural performance in terms of both cracking and ductility over single-cell specimens, in part due to the presence of transverse ribs.

- A strong panel action was noted in multi-cell specimens with a distribution factor of 0.33 .

- The proposed section showed optimal performance, as evident from its similar capacity/demand ratio in positive and negative bending.

- Despite lack of any shear reinforcement, shear specimen demonstrated high shear capacity for the proposed thin-walled box-cell section with a demand/capacity ratio of 1.7 .

- Due primarily to the steel fiber pullout mechanism of UHPC, shear failure was not sudden or abrupt, but rather ductile. 


\section{CHAPTER 4}

FINITE ELEMENT MODELING VALIDATION AND ASSESSMENT OF THE

\section{SERVICE LIMIT STATE OF THE NEW ROOF SYSTEM}

\subsection{Introduction}

Experimental program on the short-length laboratory specimens (9-ft.) demonstrated that the given roof profile successfully met the ultimate flexure and shear strength for a 20-ft. wide span. However, the Florida Building Code (2010) requires roof to have adequate stiffness to not exceed deflection reported in Table 2-1 under service loads, as well as having adequate resistant against a 300-lb. point load on a 2.5 x $2.5 \mathrm{ft}$. square area at mid-span. In order to assess the deflection of the full-length design span (20 ft.) using test results from shorter laboratory specimens (9 ft.), a non-linear deflection prediction method was needed to estimate deflection of the 20 -foot span at service load. In this regard, finite element analyses -- using general purpose finite element analysis package software Abaqus -- was employed as the non-linear prediction method to evaluate the service deflection of the full-length design span. For this purpose, finite element (FE) models of laboratory specimens ( $9 \mathrm{ft}$. span length) were developed, calibrated and verified with testing results from the previous chapter. Calibrated models were then used to develop the 20-foot long models to predict and evaluate the service deflection requirements.

\subsection{Finite Element Modeling Verification}

This chapter includes the finite element analysis of simply supported experimental specimens (SC-P, SC-N, MC-P and MC-N) as well as the 20-ft multi-cell panel. The 
geometric details and boundary conditions are accurately identical to the laboratory specimens, with the aim of providing identical comparison between the laboratory results and numerical models. Abaqus finite element software package was utilized to develop the three dimensional, static modeling of the experimental specimens.

\subsubsection{Boundary Conditions}

Figure 4-1 illustrates the geometry and boundary conditions of the finite element models of laboratory specimens. One end was pinned in all three directions using the nodal restrictions of bottom edge line in order to provide the hinge bearing; while the other end was restricted in the vertical and transverse directions to simulate the roller bearing. This arrangement allowed specimens to deform longitudinally, while preventing the models from bodily movement in transverse direction. Two vertical surface pressures were applied to simulate the experimental applied load of four-point bending tests, via $6 \times 18$ in. surfaces, 12 in. offset from mid-span. But only the middle box-cell component of multi-cell models were loaded, identical to the experimental test setup, see Figures 3-12 and 3-14.

\subsubsection{Element Types}

The UHPC was modeled using enhanced and reduced integration 8-node linear 3D element C3D8R, with enabled element deletion option in order to eliminate failed elements from the stiffness matrix for additional precision. 2-node two-dimensional truss element type T3D2 was utilized to model the HSS reinforcements, merged to the UHPC elements via a hard surface-to-surface contact interaction. Figure 4-2 depicts the mesh density utilized for all models. 


\subsubsection{Material Property}

Figure 4-3 shows the stress-strain relationship of reinforcing steel HSS ChromaX 9100 (Grade 100) utilized in finite element modeling, as well as the manufacturer data. The Young's modulus was defined as 28,324.5 ksi with a Poisson's ratio of 0.3. UHPC material property was modeled with Concrete Damage Plasticity (CDP) model, the model that represent the inelastic behavior of concrete. The Young's modulus was taken 8,000 ksi with Poisson's ratio of 0.18. (Graybeal, 2006). The ultimate compressive strength was taken from the 3-by-6-in. cylinders prepared during the specimens' fabrication and tested in 28 days. The CDP plasticity parameters specified in Table 4-1 were consistent through all the FE models. Tensile strength of UHPC plays essential role on the flexural responses of roof specimen. It is defined by two parameters: ultimate tensile strength and ultimate plastic strain, which determine tensile failure due to the fiber pullout mechanism at major crack locations. 


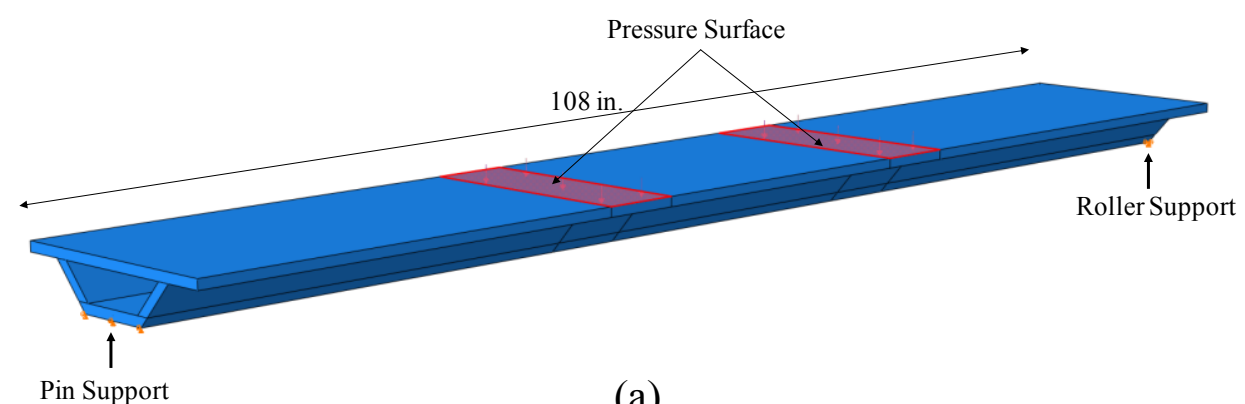

Pin Support

(a)

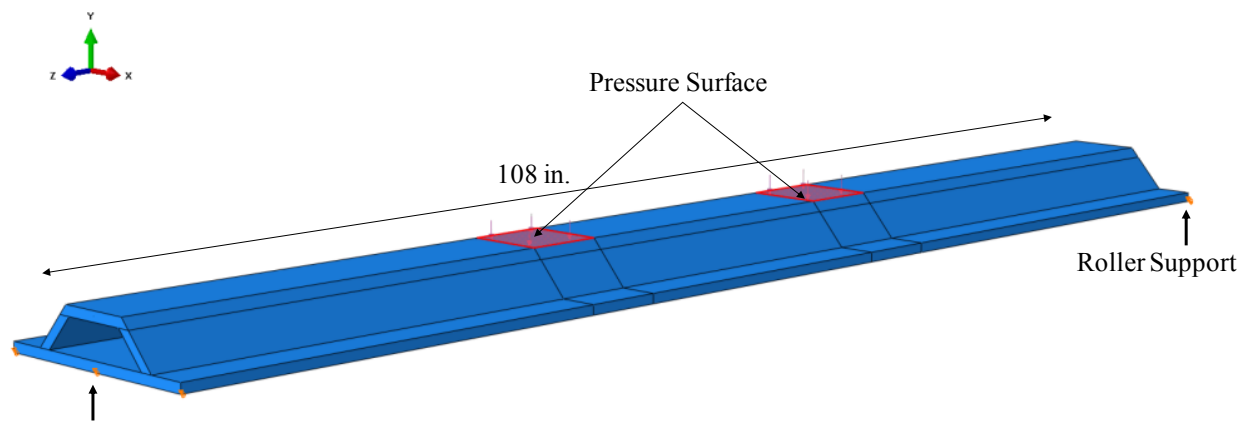

Pin Support

(b)

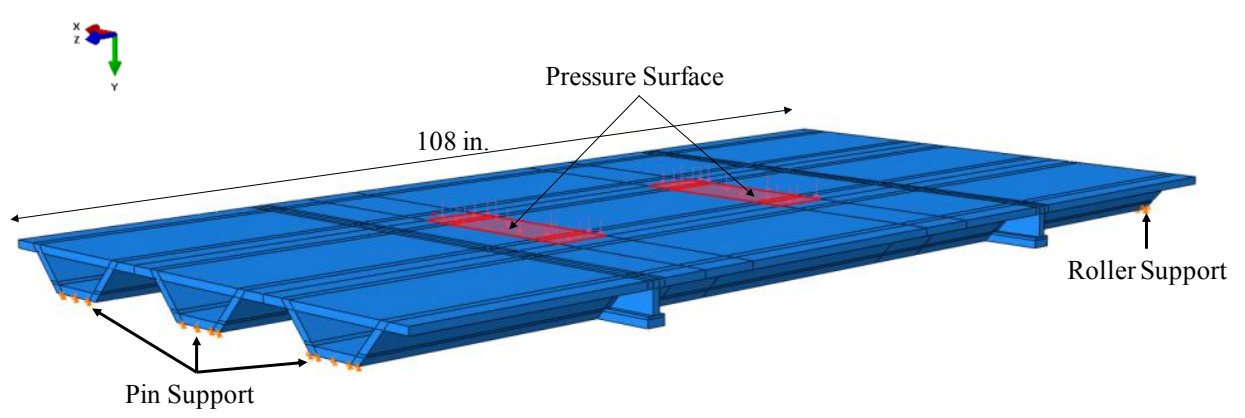

(c)

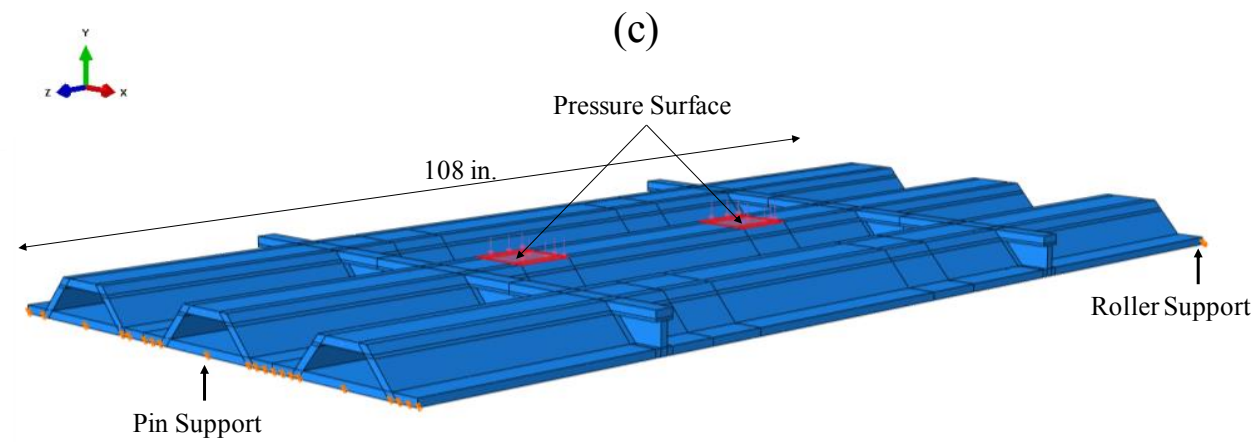

(d)

\section{7}

Figure 4-1 Finite Element model of laboratory specimens; (a) SC-P; (b) SC-N; (c) MC-P; (d) MC-N 


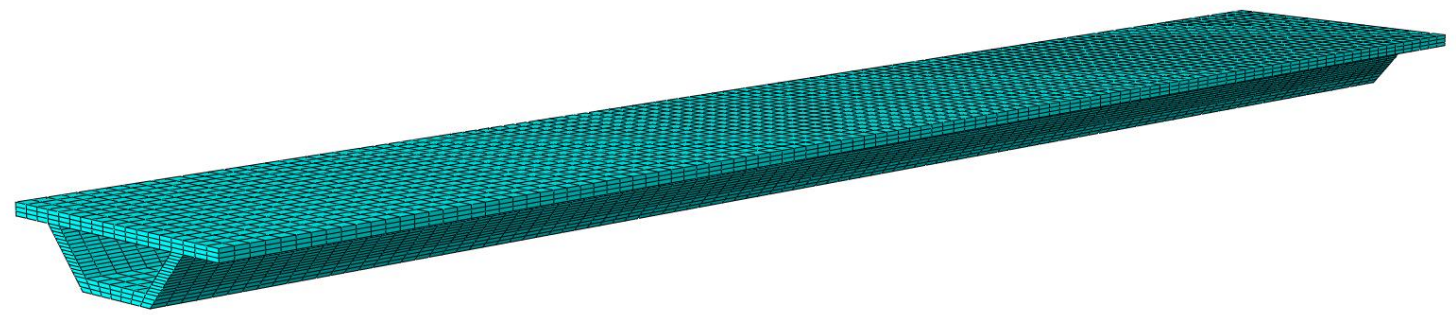

(a)

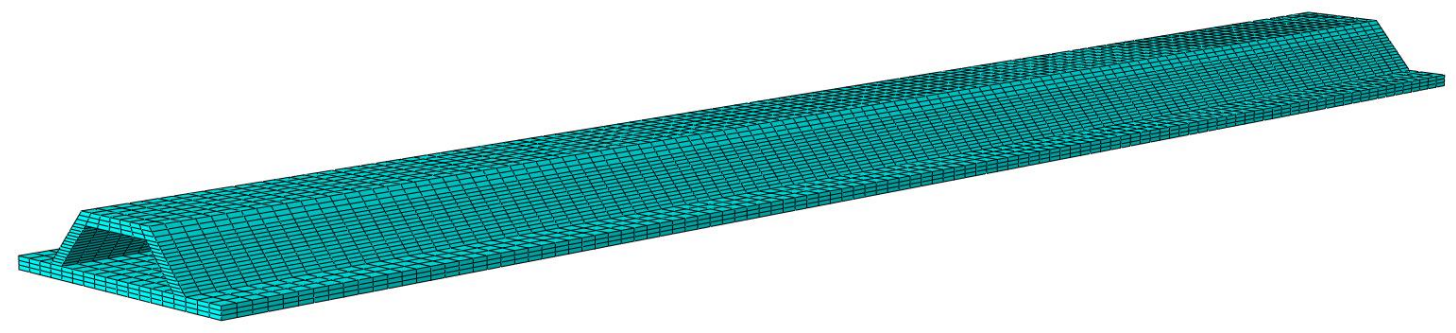

(b)

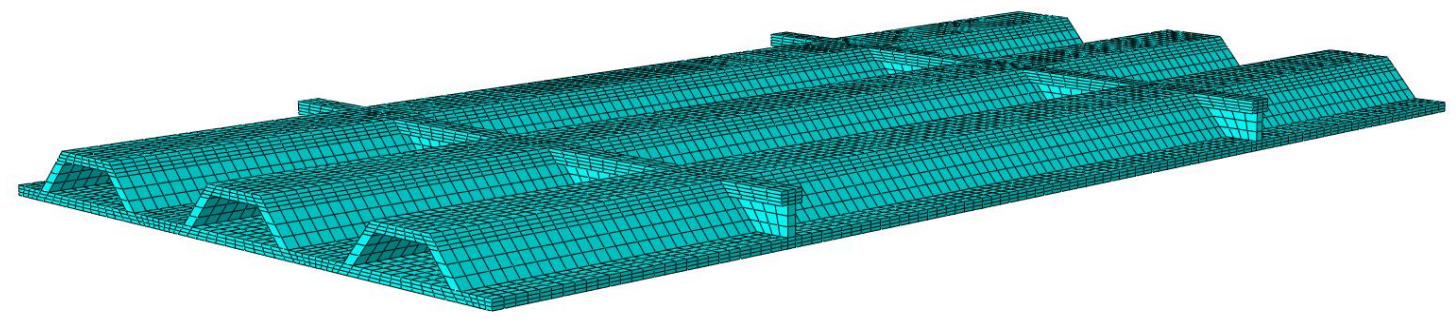

(c)

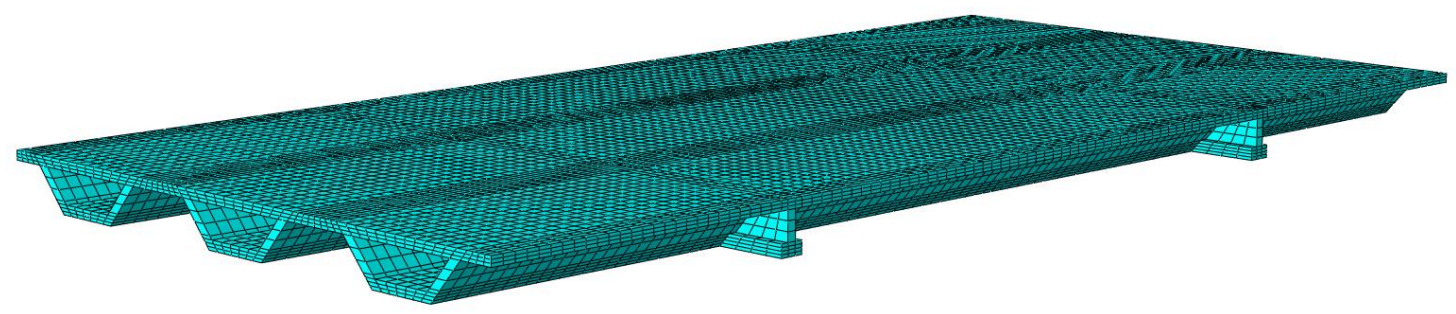

(d)

Figure 4-2 Mesh density of Finite Element models; (a) SC-P; (b) SC-N; (c) MC-P; (d) MC-N 


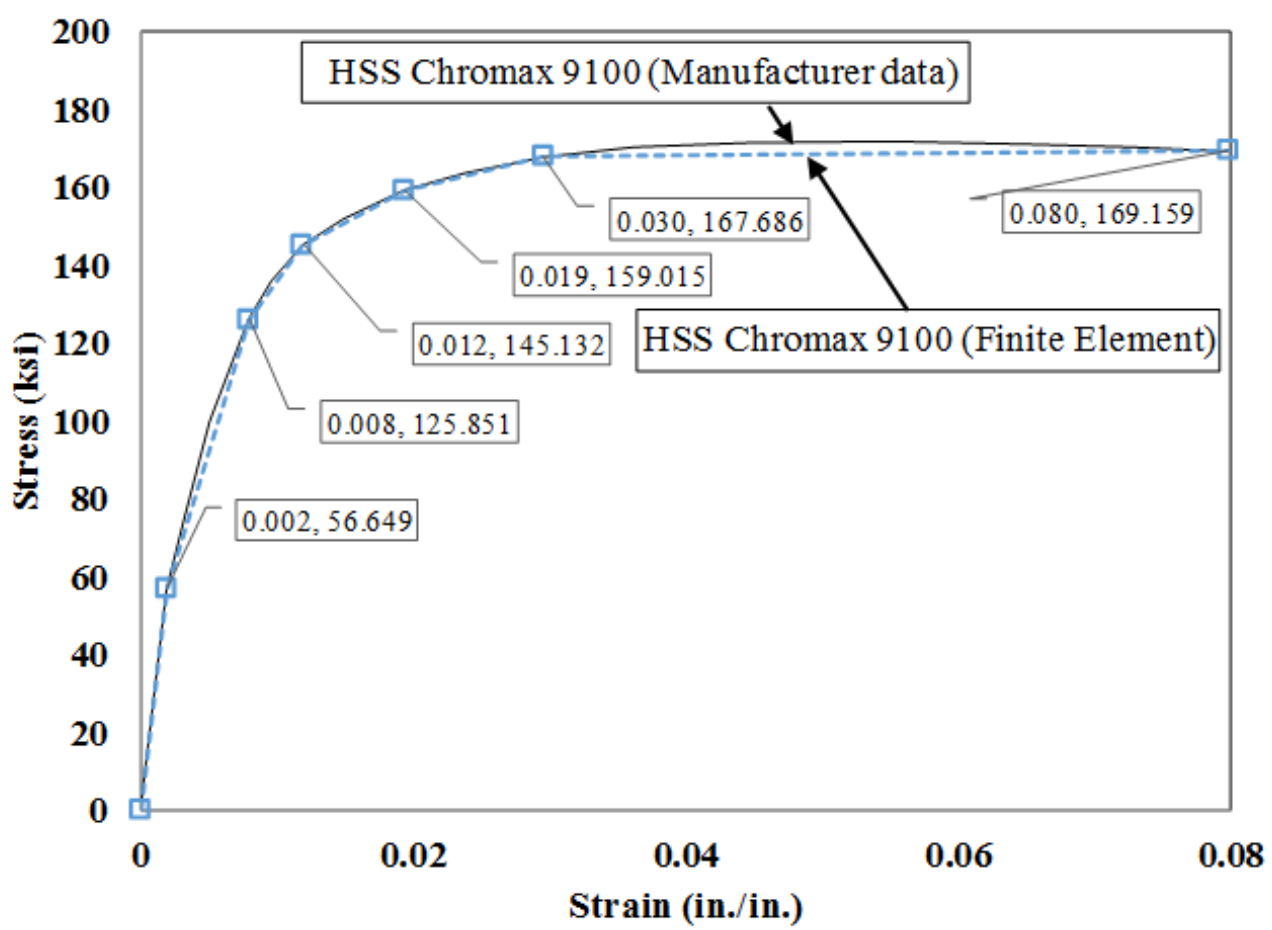

Figure 4-3 Uniaxial stress-strain responses of HSS ChromaxX 9100 (Grade 100) and equivalent responses used for FE modeling

Table 4-1 UHPC plasticity parameters defined in FE models used for all models

\section{Dilation Angle Eccentricity Fb0/fc0 K Viscosity Parameter}

$\begin{array}{lllll}15 & 1.11 & 1.16 & 0.66 & 0.001\end{array}$

\subsubsection{Finite Element Results}

The following results are based on the calibrated FE models of experimental specimens: SC-P, SC-N, MC-P and MC-N. Figures 4-4 through 4-7 depict the stress distribution along the specimens' length on deflected models, compared to the actual testing specimens. As seen in the figures, flexure is the predominant mode of failure, with flexural cracks appeared at the tension side of UHPC, identical to what observed in experimental specimens. Overall, finite element models simulated the flexural behavior of experimental specimens very well.

Figures 4-8 through 4-11 show the flexural responses resulted from FE models compared to the corresponding experimental test results. The Load-Deflection responses 
at mid-span clearly demonstrate a good agreement between the experimental and numerical results, in both elastic and plastic zones, with reasonable prediction of failure load and corresponding deflection. Table 4-2 lists the experimental failure load and deflection along with the corresponding numerical values for comparison purpose. As a result, all the FE models of laboratory specimens replicated the behavior shown in the experiments, which validate the calibration, and also can be used as benchmark toward development of fulllength models discussed next.

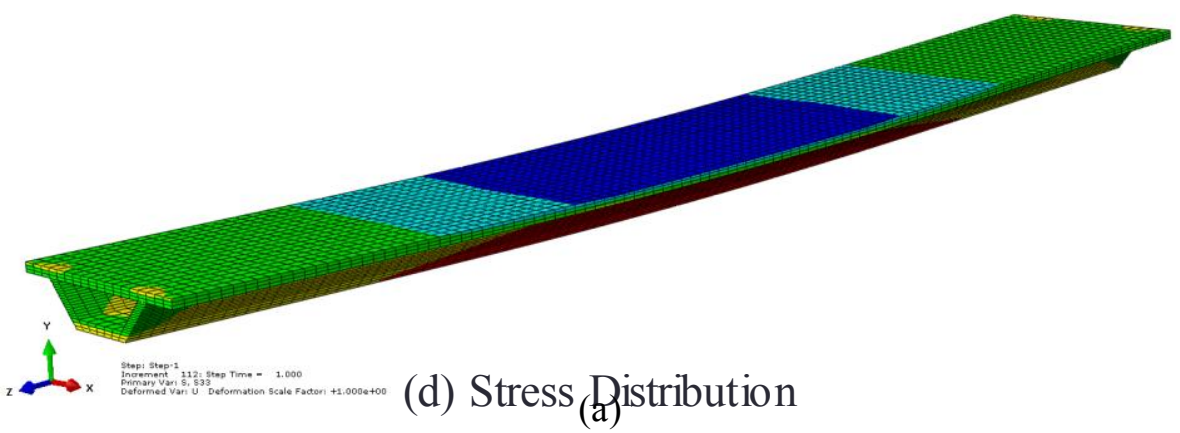

(d) Stress Distribution

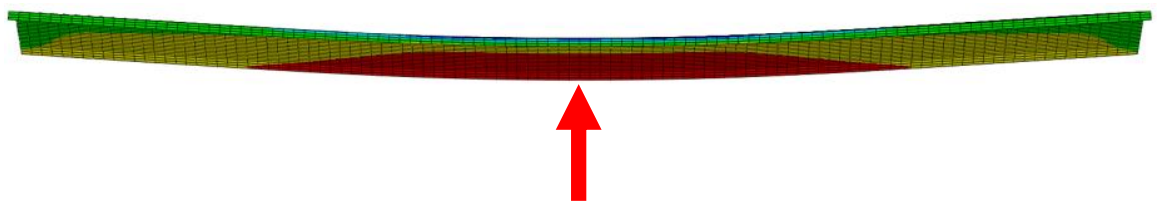

(b)
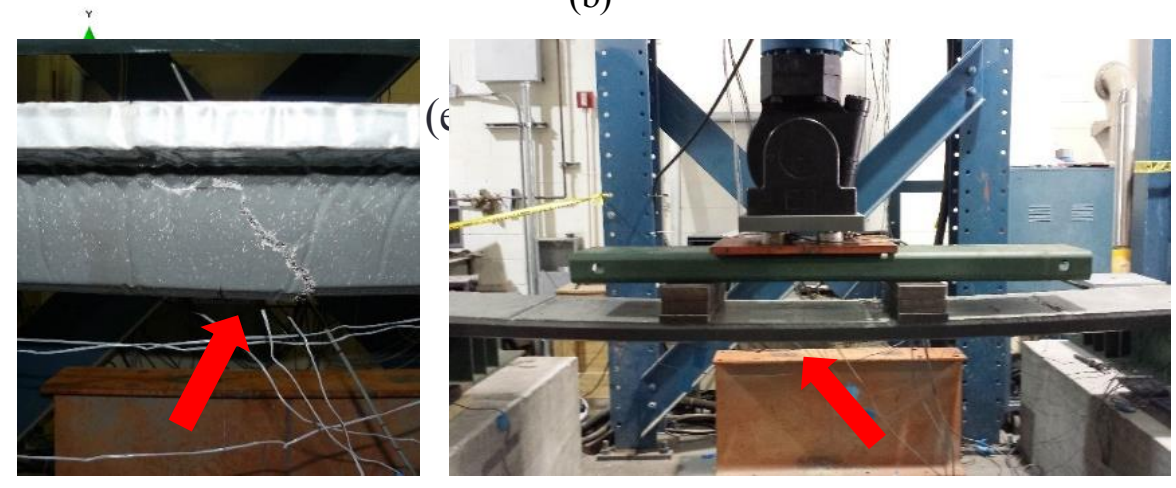

(d)

Figure 4-4 Deflected shape and failure mode of specimen SC-P: (a) Stress distribution, top view: (b) Stress distribution, side view (c) Failure mode in experimental test 


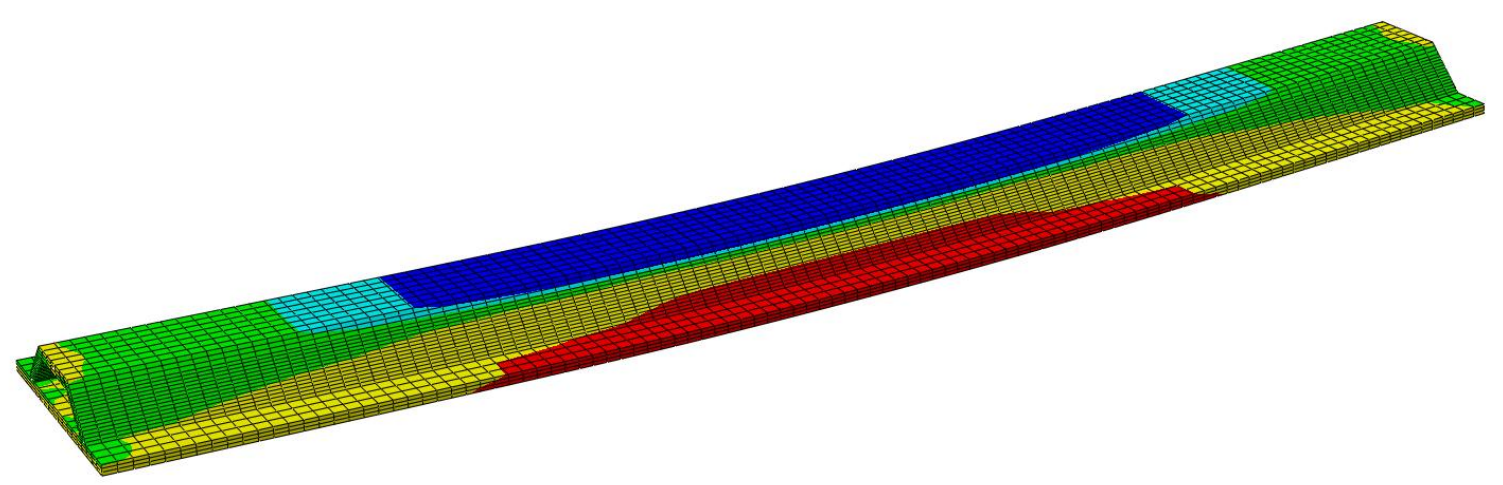

(a)

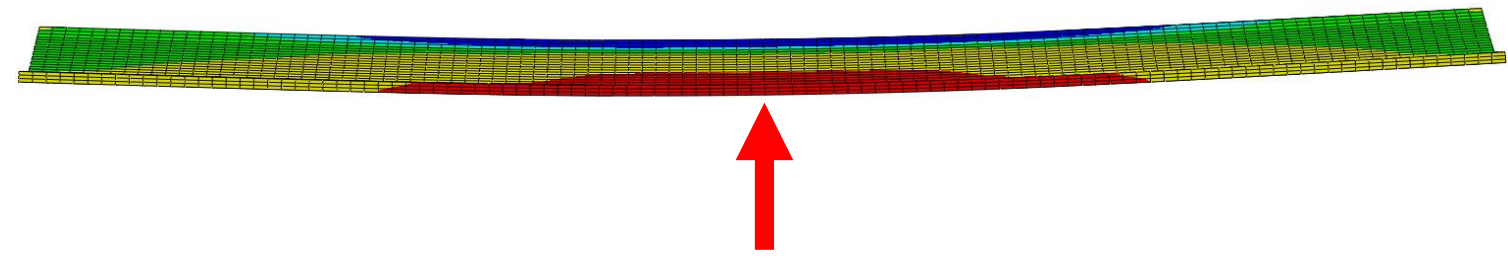

(b)
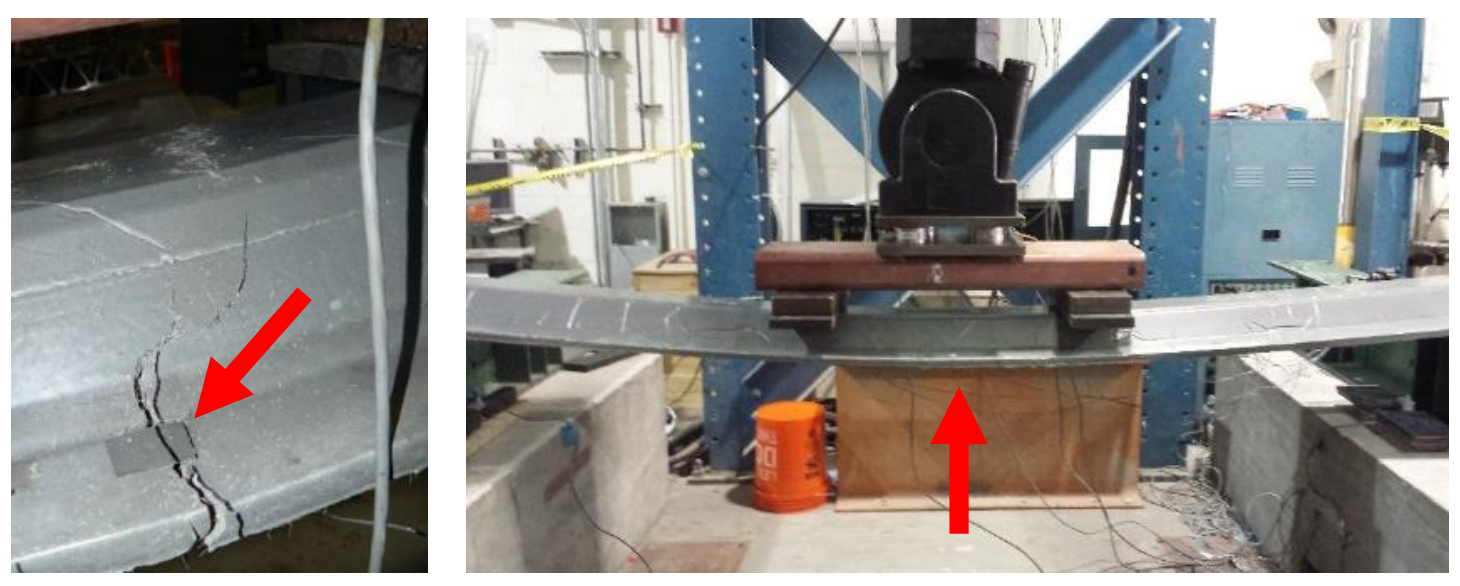

(d)

Figure 4-5 Deflected shape and failure mode of specimen SC-N: (a) Stress distribution, top view: (b) Stress distribution, side view (c) Failure mode in experimental test 


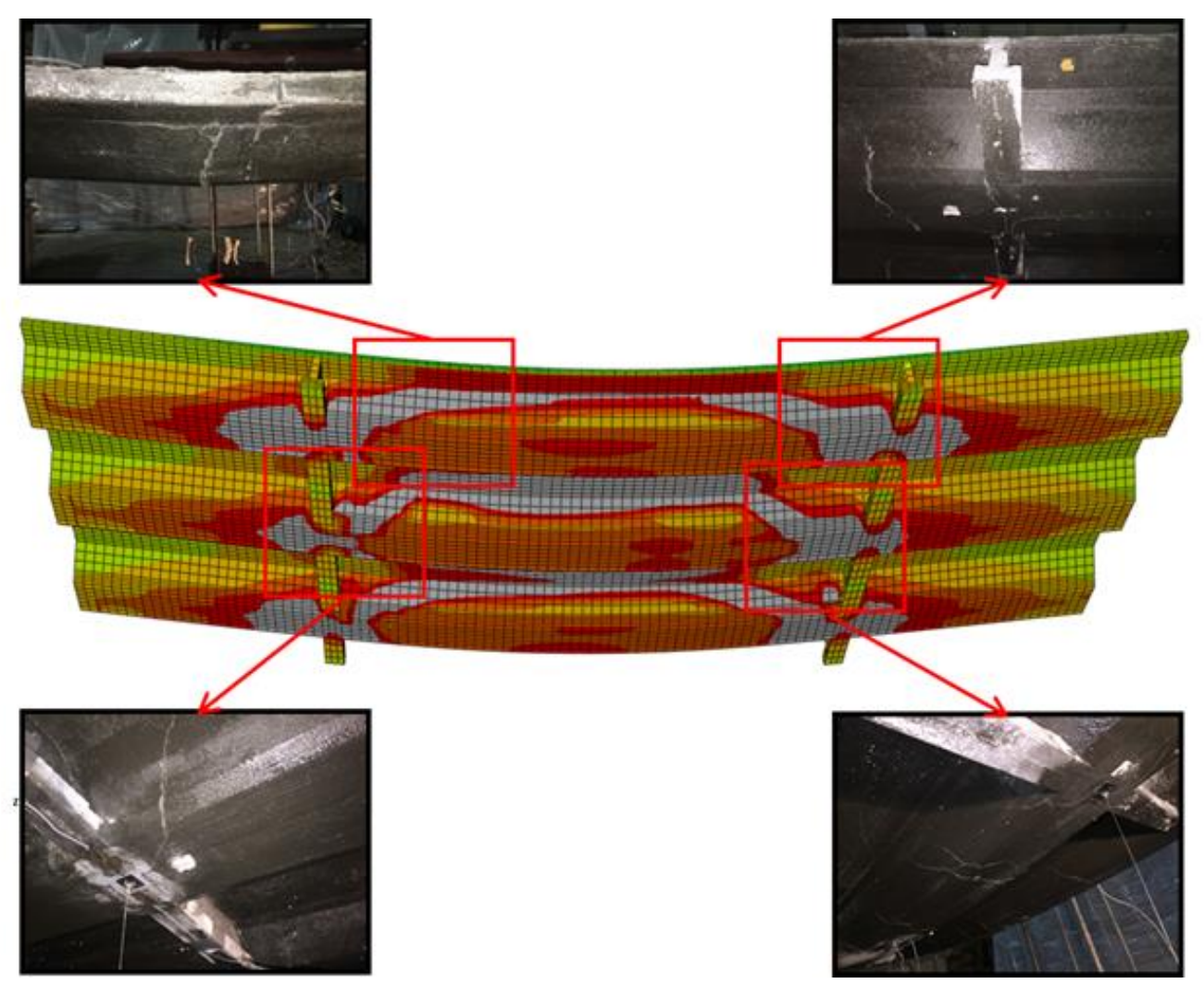

Figure 4-6 Stress distribution on the deflected shape and failure mode of specimen MC-P

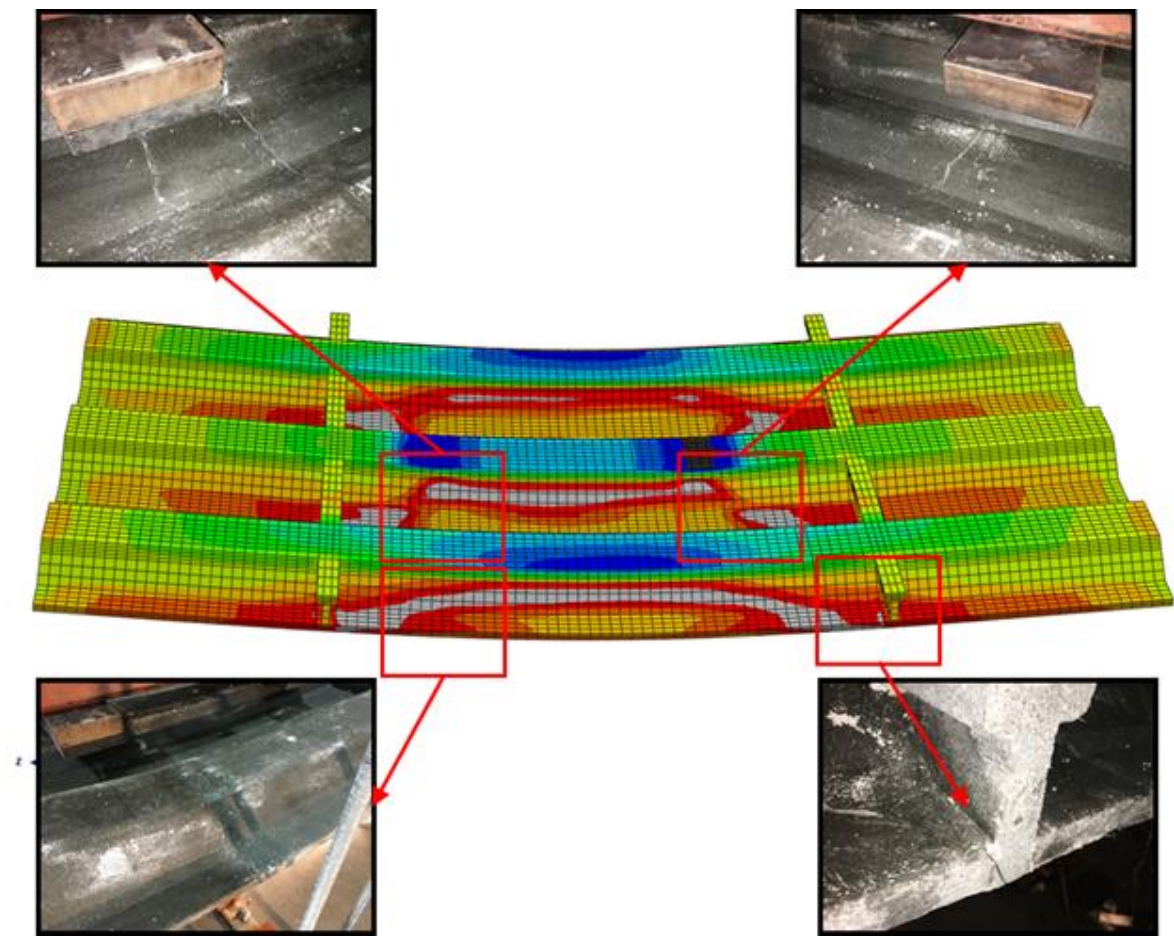

Figure 4-7 Stress distribution on the deflected shape and failure mode of specimen MC-N 


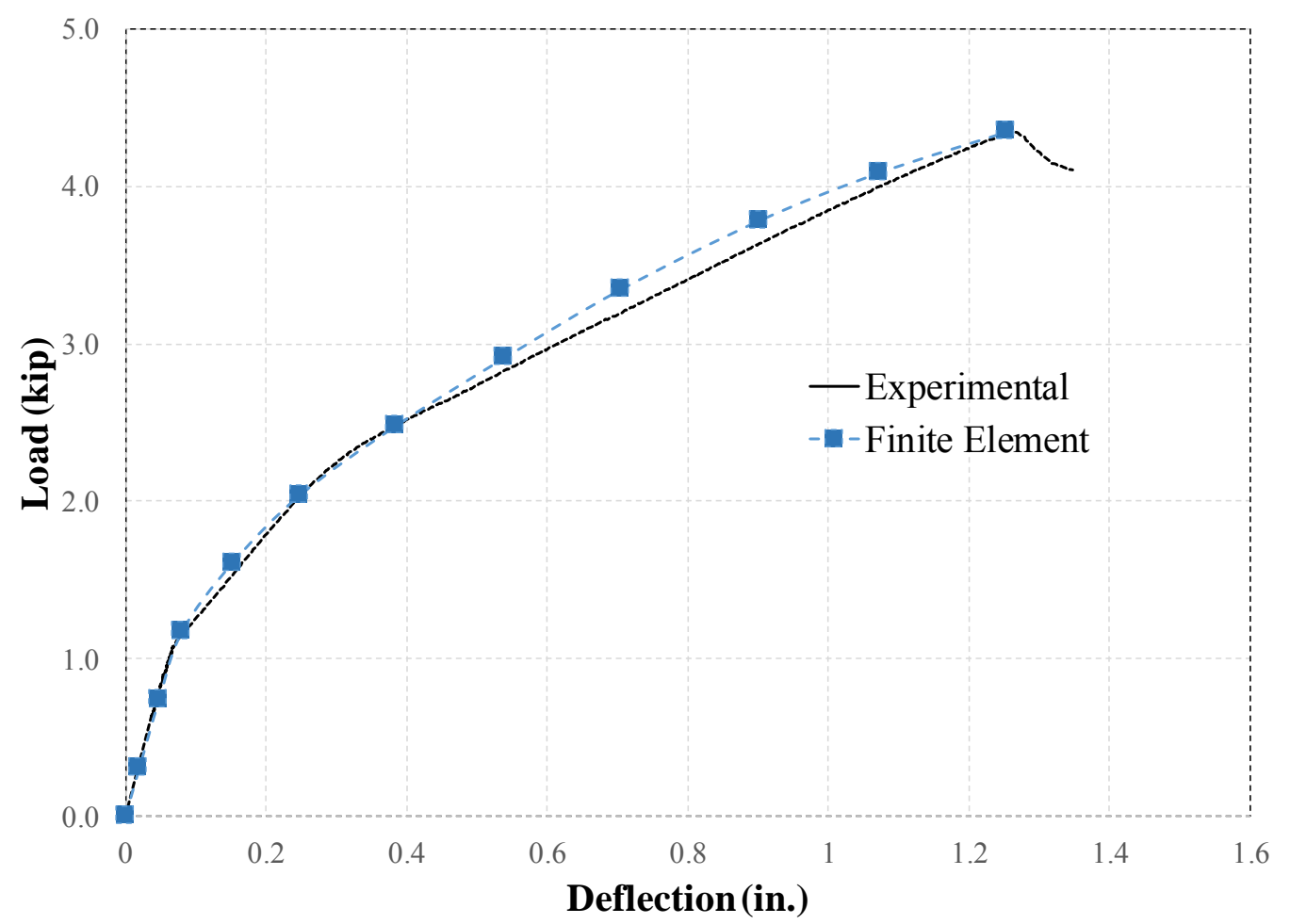

Figure 4-8 Load-Deflection response of SC-P at mid-span

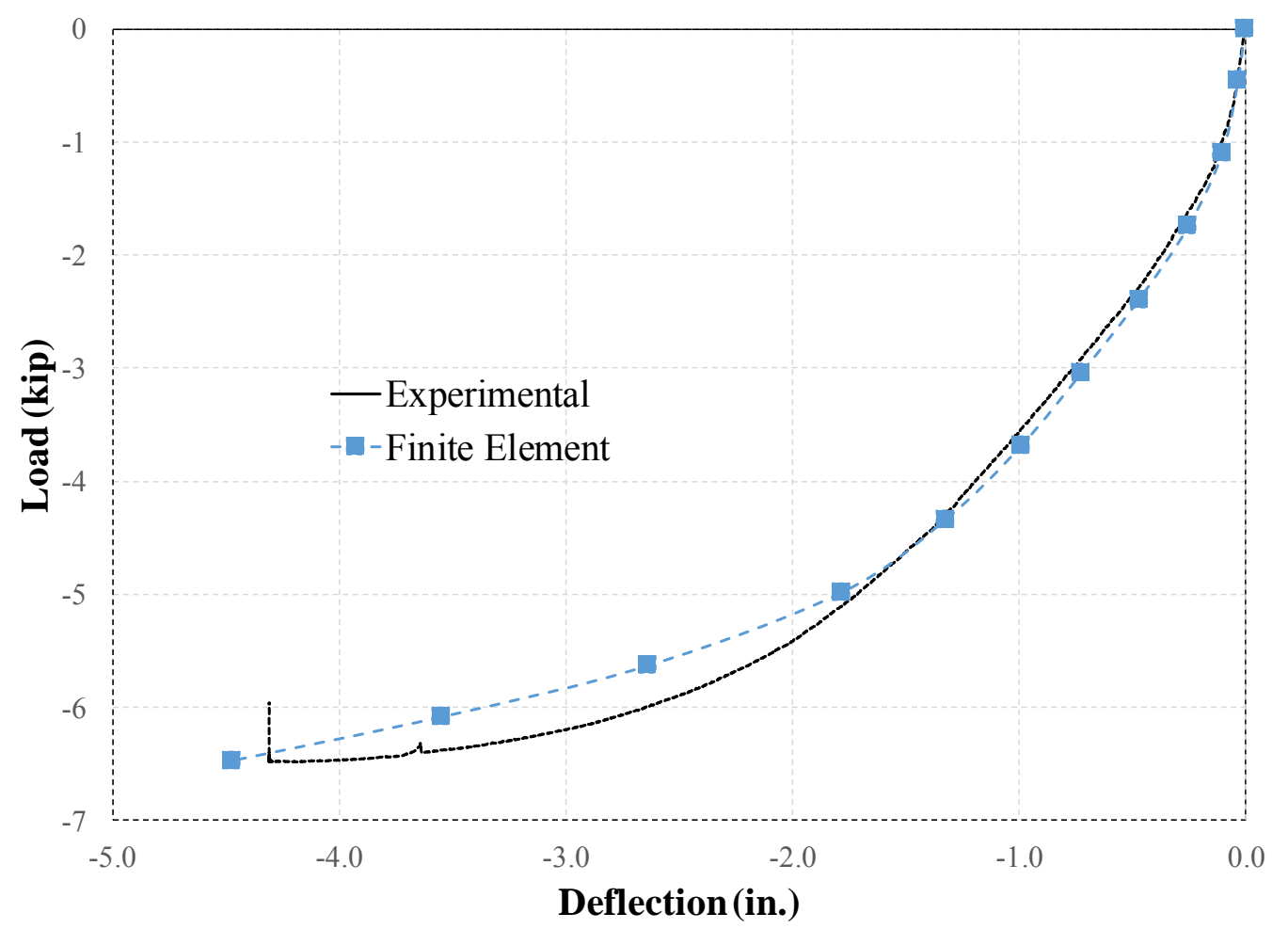

Figure 4-9 Load-Deflection response of SC-N at mid-span 


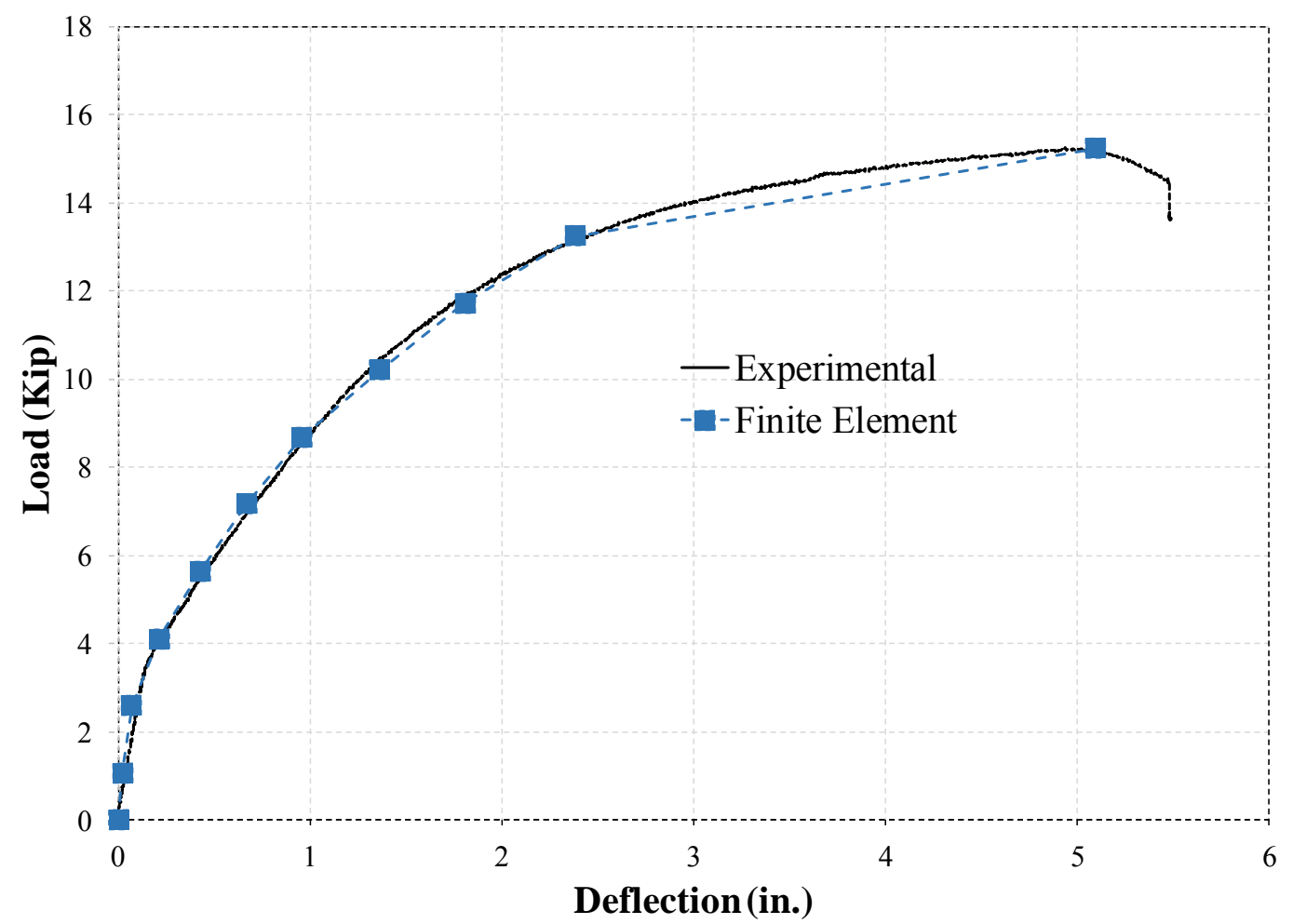

Figure 4-10 Load-Deflection response of MC-P at mid-span of middle unit (C2)

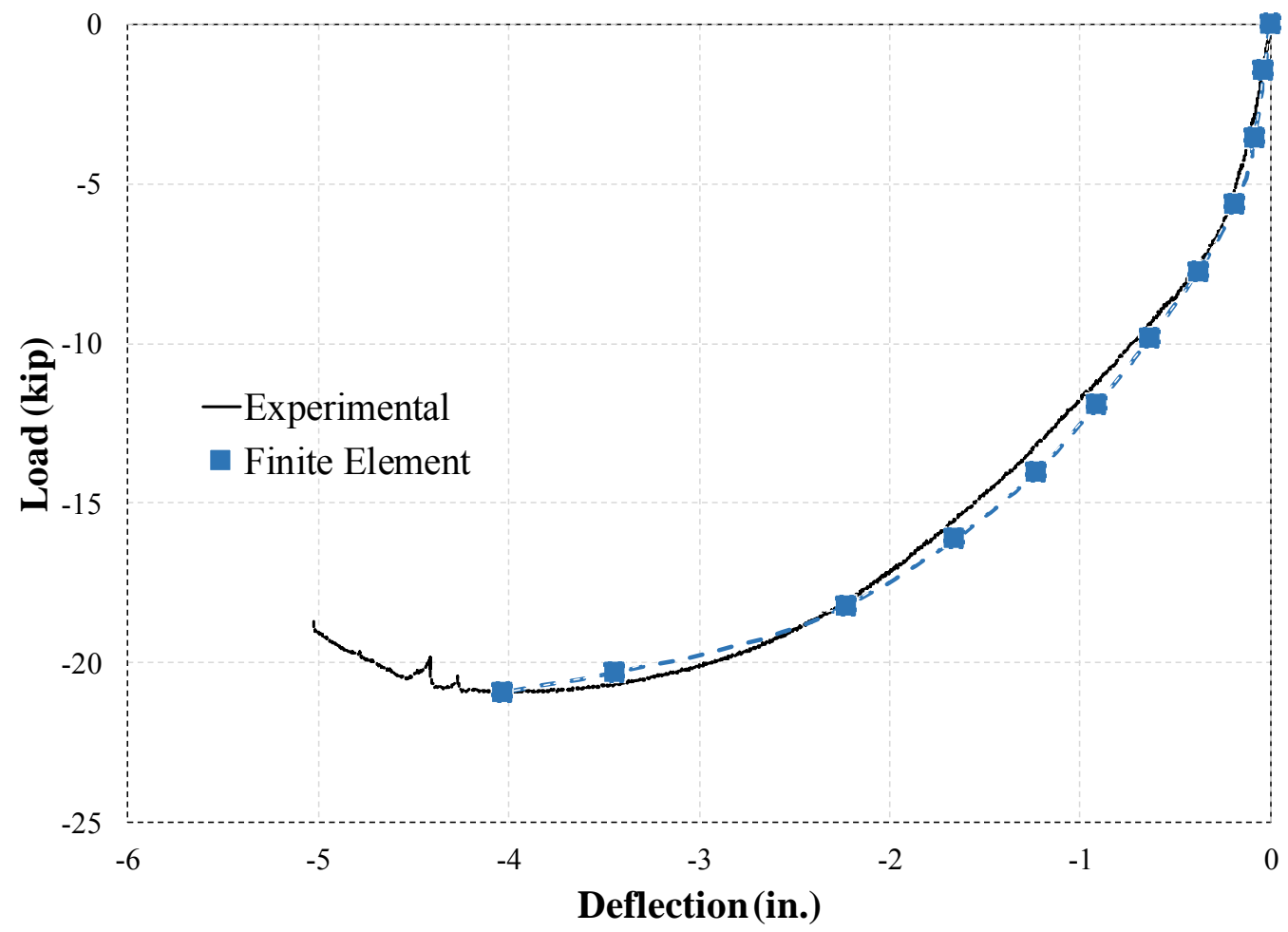

Figure 4-11 Load-Deflection response of MC-N at mid-span of middle unit (C2) 
Table 4-2 Summary of Finite Element Analyses and Experimental Results

\begin{tabular}{ccccc}
\hline \multirow{2}{*}{ Specimen } & \multicolumn{2}{c}{ Experimental } & \multicolumn{2}{c}{ FE Analyses } \\
\cline { 2 - 5 } & $\begin{array}{c}\text { Failure load } \\
\text { (kips) }\end{array}$ & $\begin{array}{c}\text { Mid-span } \\
\text { deflection (in.) }\end{array}$ & $\begin{array}{c}\text { Failure load } \\
\text { (kips) }\end{array}$ & $\begin{array}{c}\text { Mid-span } \\
\text { deflection (in.) }\end{array}$ \\
\hline SC-P & 4.35 & 1.27 & 4.35 & 1.25 \\
SC-N & 6.48 & 3.67 & 6.48 & 4.47 \\
MC-P & 15.24 & 4.94 & 15.24 & 5.10 \\
MC-N & 20.93 & 3.89 & 20.93 & 4.03 \\
\hline
\end{tabular}

\subsection{Finite Element Modeling of the Full-length Roof Panel}

As discussed earlier, the calibrated FE modeling technique was used to develop the full-length roof panel. Figure 4-12 shows the geometry, boundary conditions and imposed loads on the 20-foot multi-cell FE model roof panel. Roof model was featured with transverse ribs at every 54 in. (center to center) along the length, with hinge-roller supports at the ends, subjected to the positive and negative design loads of 77.23 and $116.25 \mathrm{lb} / \mathrm{ft}^{2}$, respectively. Figure 4-13 graphically describes the deflection limits required by the Florida Building Code (2010) that has to be checked with the model. This is the schematic of the roof system's deflection under different loading stages as follows:

1) Deflection due to its own weigh resulting in $\mathrm{D}_{1}$ deflection;

2) Deflection due to its own weight and live load, $\mathrm{D}_{2}$;

3) Deflection due to the live load itself, $\mathrm{D}_{3}$; and

4) Deflection due to wind uplift pressure, D4.

According to the code, $\mathrm{D}_{2}$ is limited to the $1 / 180$ of span length, equivalent to 1.33 inches for the 20-foot span. Also, deflection caused by the live load itself $\mathrm{D}_{3}$ (calculated by subtracting $\mathrm{D}_{1}$ from $\mathrm{D}_{2}$ ) should not exceed $1 / 240$ (1.0 in.). Deflection due to the wind uplift pressure $\left(D_{3}\right)$ must be less than 1.0 in. allowable deflection $(1 / 240)$. Table $4-3$ lists 
the allowable deflections for roof supporting nonplaster ceiling, and respective finite element results for the 20 -foot long model

\subsubsection{Finite Element Results}

Figure 4-14 shows all the above-mentioned transitions as a load-deflection response, resulted from FE model. The bending capacity is same as that obtained in experimental program on MC-P and MC-N specimens, with estimated maximum deflection of 21.40 and 16.36 in. at mid-span under peak load of positive and negative pressure, respectively. By examining the model, all the deflection requirements were successfully satisfied. The predicted deflection at mid-span due to the self-weight of the system is 0.28 inches, that increases to 0.99 inches by adding the live load of $20 \mathrm{lb} / \mathrm{ft}^{2}$, which resulted deflection less than the permitted limit of 1.33 inches (1/180). Deflection due to the live load itself is 0.63 inches, which is still less than 1.0-inch allowable deflection (1/240). Under wind uplift pressure, roof convexes 0.86 inches upward, which is still less than permitted deformation of 1.0 inches $(1 / 240)$. It should be noted that wind load is permitted to be taken as 0.42 times the "component and cladding" loads for the purpose of determining deflection limits, according to the Florida Building Code. All the values are summarized in Table 4-3.

The 300-lb concentrated load at mid-span of the 20-ft-span -- due to the workers on the roof during the construction -- induces $1.5 \mathrm{kip}$-ft. positive moment, which is significantly lower than the ultimate flexural capacity of single-cell and multi-cell specimens, as they are 7.06 and 24.77 kip-ft., respectively. Hence, the proposed system successfully resists the point load, thus fulfilling the requirement. Consequently, the given roof section 


20 ff. $\stackrel{\text { Pressure Surface }}{439 \text { in. }}$

Hin

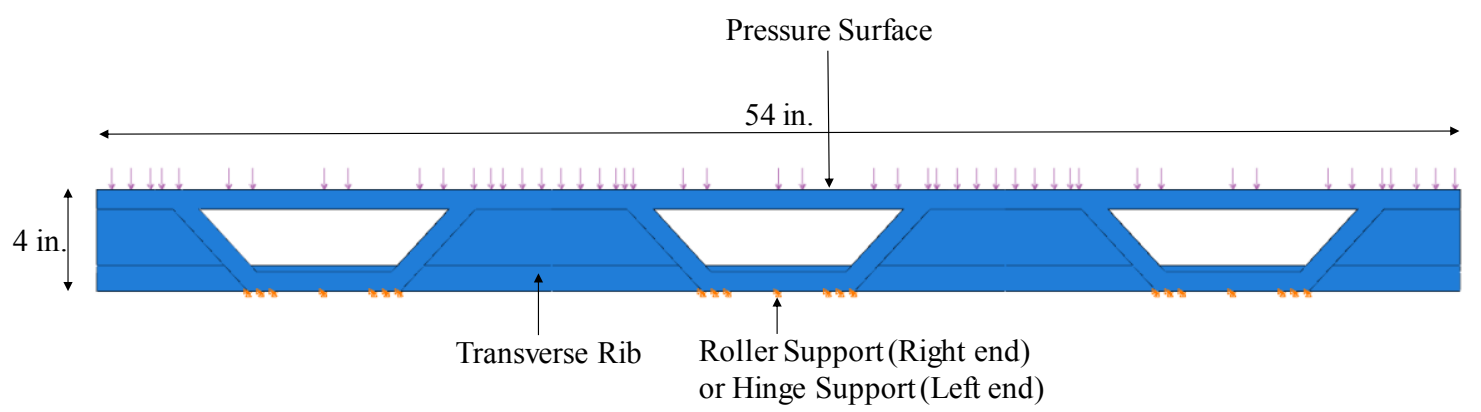

(b)

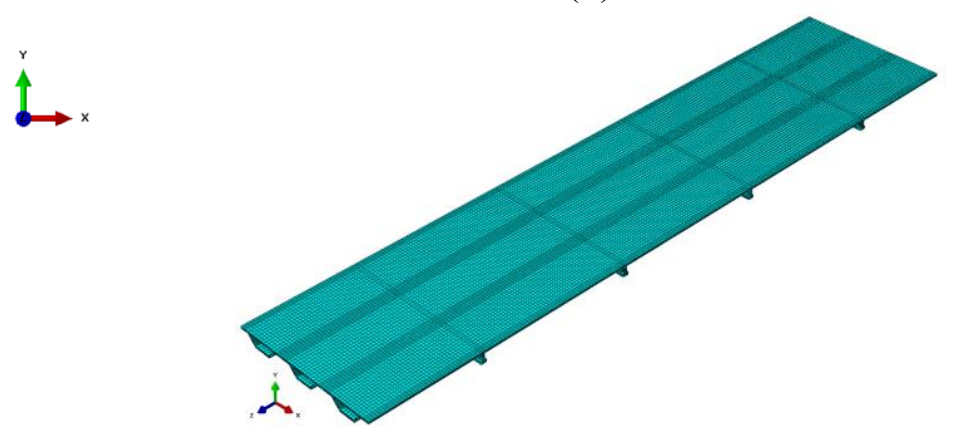

(c)

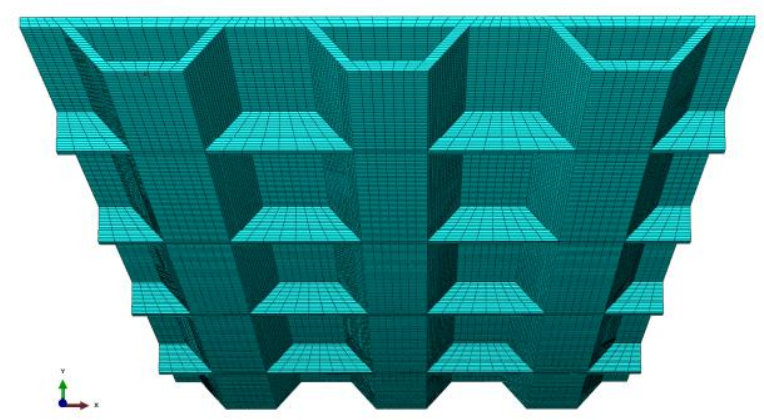

(d)

Figure 4-12 Finite Element model of 20-foot multi-cell roof panel: (a) Side view; (b) Cross section; (c) Top view; (d) Bottom view 


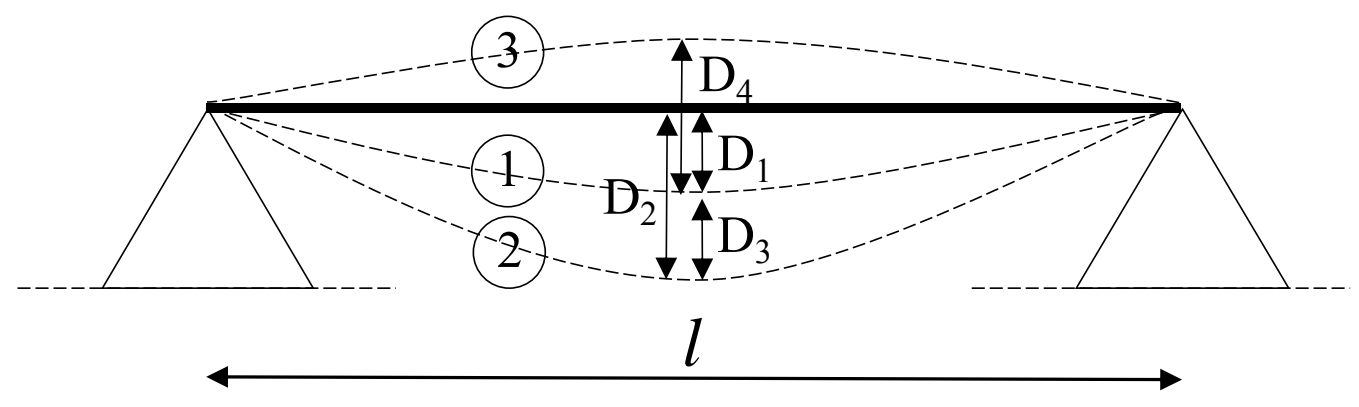

$\mathrm{D}_{1}$, Deflection due to the self-weight,

$\mathrm{D}_{2}$, Deflection due to the self-weight and live load, must be less than $l / 180^{*}$

$\mathrm{D}_{3}$, Deflection due to the live load itself, must be less than $l / 240^{*}$

$\mathrm{D}_{4}$, Deflection due to the wind uplift pressure, must be less than $l / 240 *$

*For nonplaster ceilings (see Table 4-3)

Figure 4-13 Deflection states at loading conditions

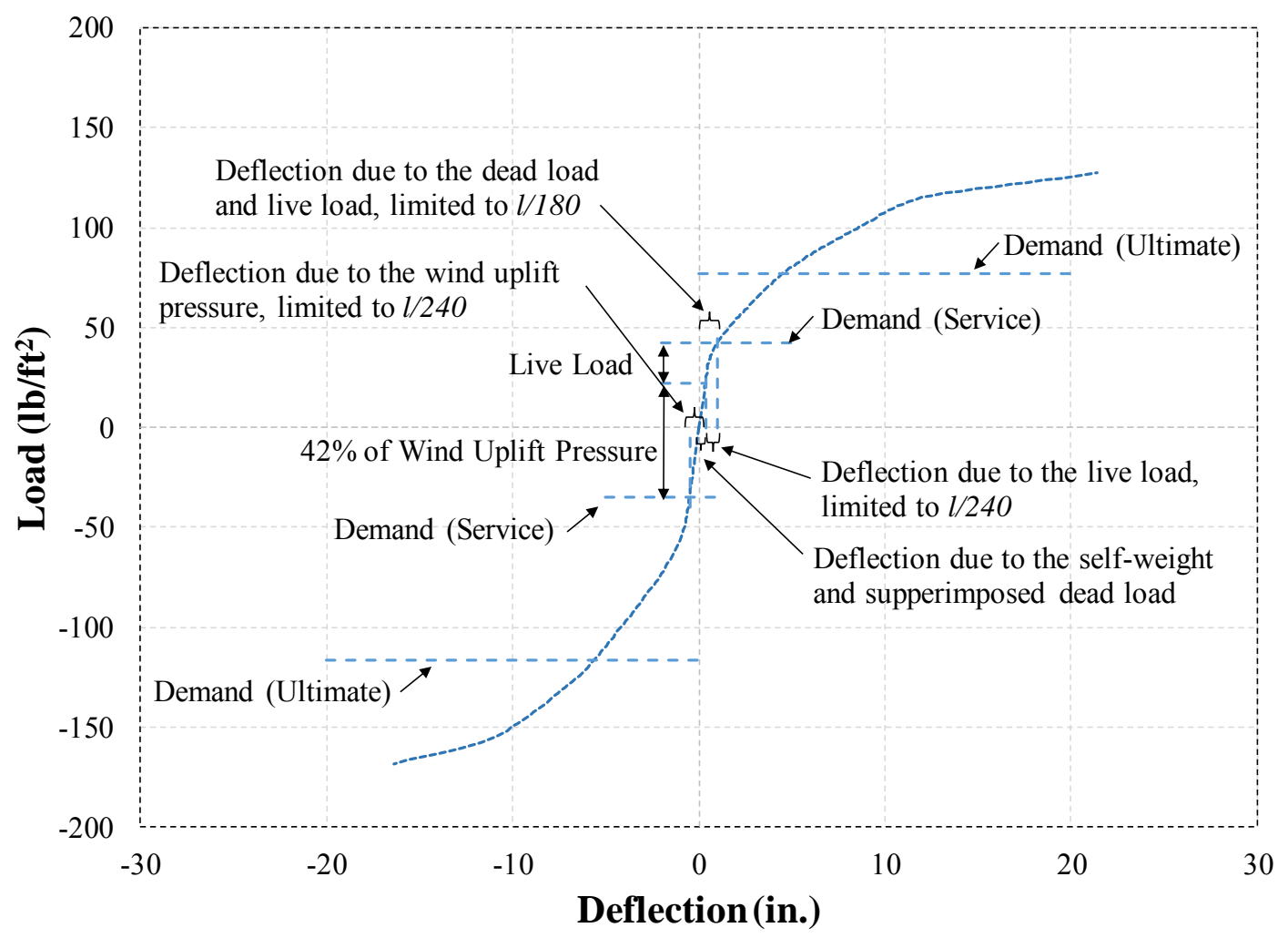

Figure 4-14 Load-Deflection response of proposed roof panel for $20 \mathrm{ft}$. span with nonplaster ceiling, resulted from finite element models 
Table 4-3 Allowable deflections for roof supporting nonplaster ceiling, and respective finite element results for the 20 -foot long model

\begin{tabular}{|c|c|c|c|c|c|c|}
\hline \multirow{2}{*}{$\begin{array}{c}\text { Span } \\
\text { length }[\mathrm{ft} .]\end{array}$} & \multicolumn{3}{|c|}{$\begin{array}{c}\text { Allowable deflection } \\
\text { [in.] }\end{array}$} & \multicolumn{3}{|c|}{$\begin{array}{l}\text { Deflection resulted from FE models } \\
\text { [in.] }\end{array}$} \\
\hline & $\begin{array}{c}L \\
{[L / 240]}\end{array}$ & $\begin{array}{c}\mathbf{W} \\
{[\mathrm{L} / \mathbf{2 4 0}]}\end{array}$ & $\begin{array}{c}\mathbf{L}+\mathbf{D} \\
{[\mathbf{L} / \mathbf{1 8 0}]}\end{array}$ & $\begin{array}{c}\mathbf{L} \\
{[\mathbf{L} / 240]}\end{array}$ & $\begin{array}{c}\mathbf{W} \\
{[\mathrm{L} / \mathbf{2 4 0}]}\end{array}$ & $\begin{array}{c}\mathbf{L}+\mathbf{D} \\
{[\mathbf{L} / \mathbf{1 8 0}]}\end{array}$ \\
\hline 20.0 & 1.00 & 1.00 & 1.33 & 0.63 & 0.86 & 0.99 \\
\hline
\end{tabular}

\subsection{Conclusions}

Overall, finite element models simulated the flexural behavior of experimental specimens very well. Experimental tests and finite element analyses confirmed that the proposed roof system has adequate stiffness and strength for roofs supporting nonplaster ceiling up to 20 -foot wide span. As a consequence, it can be concluded that the 20 -footspan designed system successfully meets all the requirements - including flexural strength, shear strength and serviceability deflections -- specified by the Florida Building Code (FBC 2010) for the hurricane-prone U.S. regions. 


\section{CHAPTER 5}

\section{DEVELOPMENT OF CONNECTIONS}

\subsection{Introduction}

The connections proposed in this study are one of the possible options to demonstrate the capabilities of the system for future works. Also, it is left open to the engineer to design the ideal connection for the given project, as needed, based on the building structural system type, geographical location, constructability needs, available equipment, magnitude of forces, assembly and erection considerations and etc. However, in this study two types of connections are proposed as examples; (1) connection that secures the panels and adjacent panels as a unit, termed as Panel-to-Panel connection; and (2) Roofto-Wall connection that attaches roof panels to the supporting walls or beams. In suggesting the connection, it was considered to keep the installation simple, compatible with most building systems, and make the on-site construction of the roof easy and flexible.

\subsection{Panel to Panel Connection}

Panel-to-Panel connection is composed of two compartments, as depicted through the 3D schematic in Figure 5-1: (1) Flange connection; and (2) rib connection. Flange connection is a cast in-place UHPC fill on depressed top flanges at the end of panels' width, see Figure $5-1$ (b). The UHPC fill is $3 / 4$ inch-thick - same thickness as top flange. Flange connection is the compartment that resists the longitudinal flexural moments -- the major load on the connection due to the one-way slab action -- as was previously confirmed in Chapter 3. Rib connection is the compartment that withstands shear forces induced by 
loading difference on adjacent panels, with two available options: (a) bolted-steel plates; and (b) post-tensioning (see Figure 5-1 (a) and (c)). The first component of Panel-to-Panel connection, flange connection, is the mandatory part, but the second component, rib connection, is optional based on the loading conditions. In this study, flange connection is investigated through the simplified experimental work; while the use and design of the rib connections are left upon the designer's judgment for designing based on the magnitude of loads, construction need, assembly and erection considerations, etc.

The purpose of optional rib connection is to resist shear load caused by the probable different loading on two adjacent panels. Typically, in a normal operation, there is no loading difference on two neighboring panels. As previously stated, it is left to the designer to design the appropriate rib connection based on the job characteristics and needs; however, the two proposed mechanical rib connections in this study provide adequate resistance for most projects. The first option, bolted connection, link the web of transverse ribs using a single or double bolted steel plates, depends on the magnitude of forces. Double steel plates sandwiches transverse ribs using bolts run through the pre-installed throughholes in the web of transverse ribs, as depicted in Figure 5-1 (a and c). The size of bolts and plates can simply be designed. The bolts can be subjected to either single or double shear, depends on the number of palates used. Another alternative, post-tensioning, may be utilized along the width of panels using post-tensioning cables run through the preinstalled through-hole in the bottom flange of transverse ribs, as illustrated in the 3D perspective in Figure 5-1 (a and c). Both options, bolted connection and post-tensioning as the rib connections, are available based on the need and designer decision. 


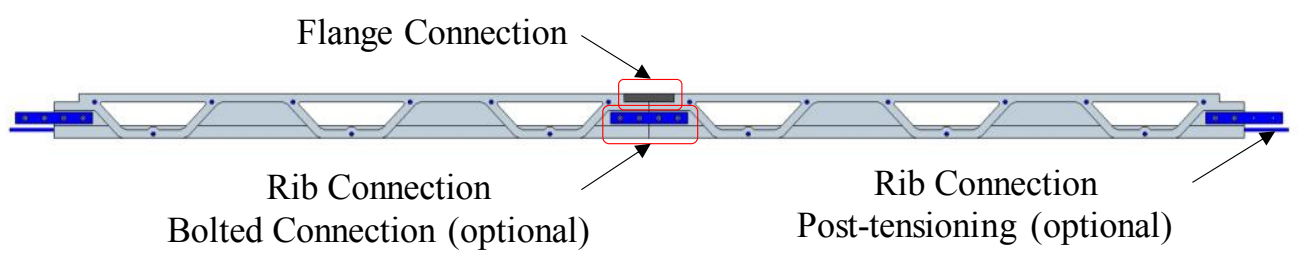

(a)

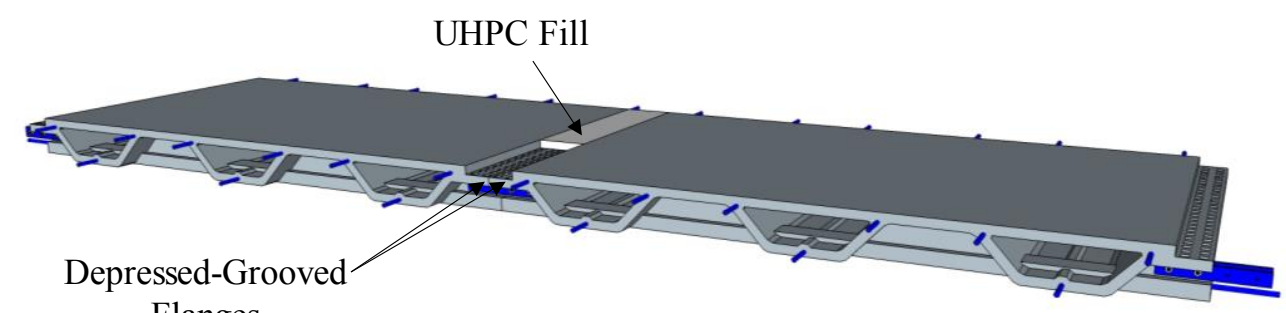

(b)

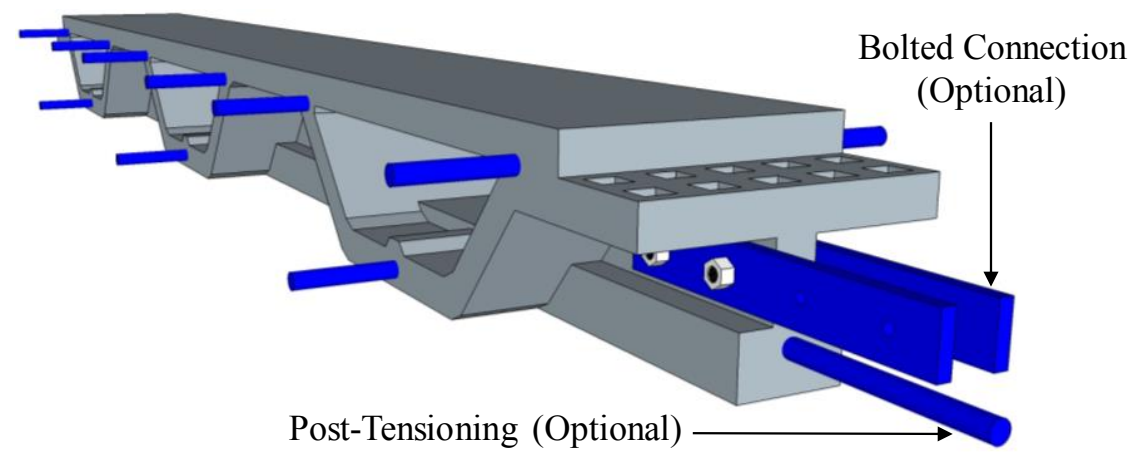

(c)

Figure 5-1 Panel-to-Panel connection and its components: (a) Components of Panel-to-Panel connection; (b) Flange connection; (c) Rib connection

The mandatory component of panel-to-panel connection, flange connection, is mainly introduced to:

1) link the top flanges;

2) allow full continuity across the entire roof finish;

3) resist longitudinal moment forces, both negative and positive; and 
4) to be served as water tightness material.

For this purpose, flanges at the end of panel's width are depressed (see Figure 5-1 (b)) in order to: (1) be served as the self-form for UHPC fill; (2) provide adequate room for joint to maintain top finish flush; and most importantly (3) provide a platform to link top flanges by UHPC fill. In order to provide adequate bond and interlock between UHPC fill and the two adjacent flanges, depressed flanges are featured with grooves (1/4-in. deep, by $9 / 16$ in. square footprint arranged in grids along the panel's length as shown in Figure 5-2 (a)) that act as a tongue-in-groove when joint filled with fresh UHPC. Tongue-ingroove mechanism leads to composite behavior by transferring shear force at interaction surface. No additional material or component is needed (e.g. steel shear stud), therefore, the manufacturing and installation is very simple, quick, and no extra considerations required. Joints should only be filled with fresh UHPC when roof panels installed. 


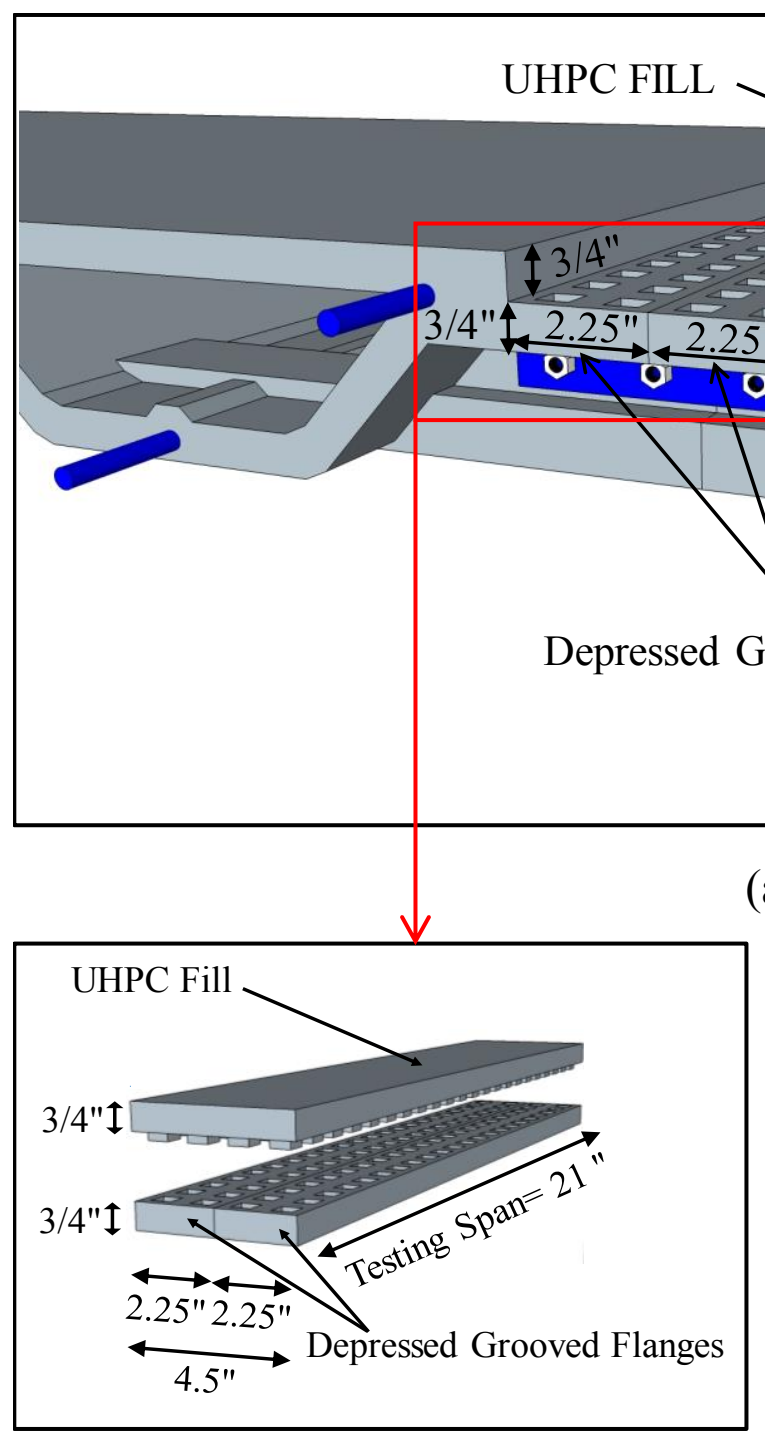

(b) (a)

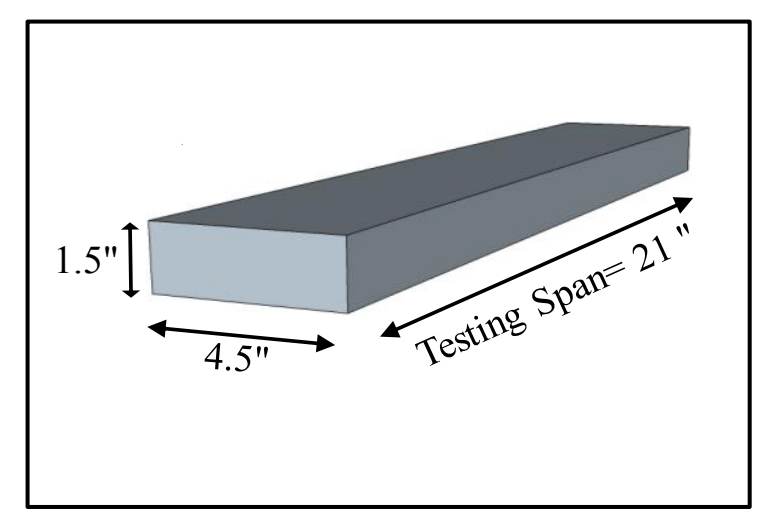

(c)

Figure 5-2 Details of flange connection as the Panel-to-Panel connection compartment; (a) Geometric details; (b) Geometric details of Group1 connection specimens; (c) Geometric details of Group 2 specimens 

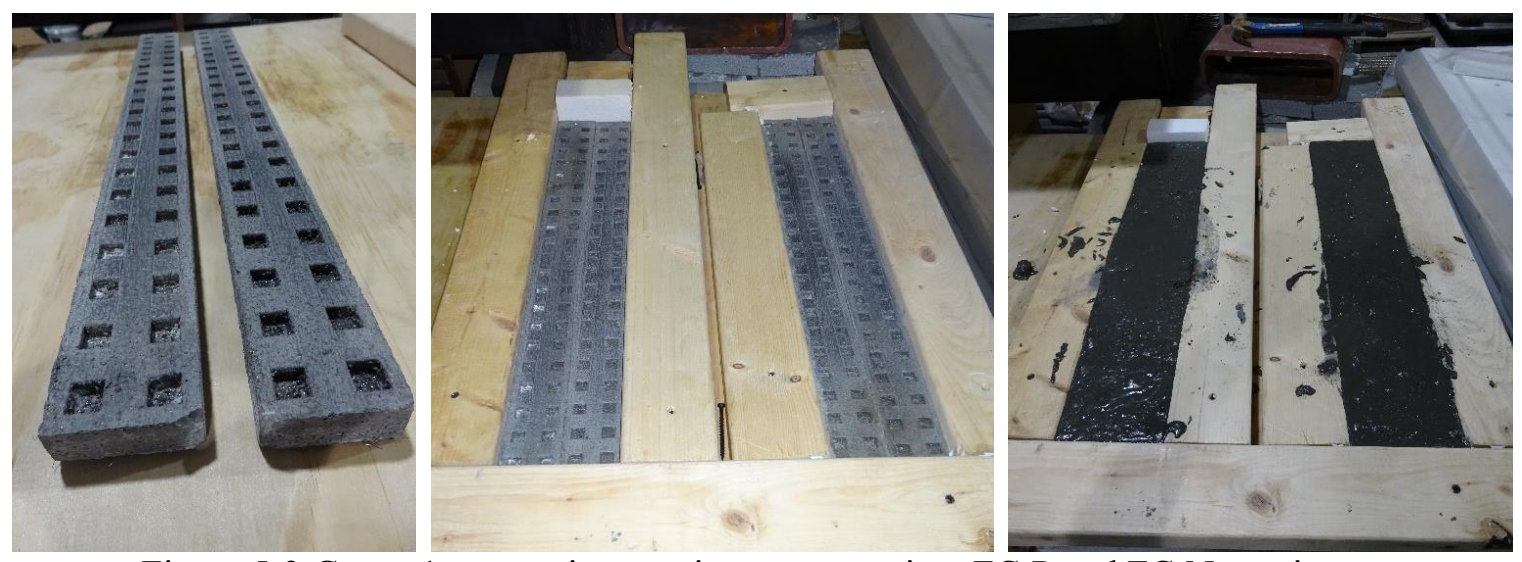

Figure 5-3 Group 1 connection specimen preparation, FC-P and FC-N specimens

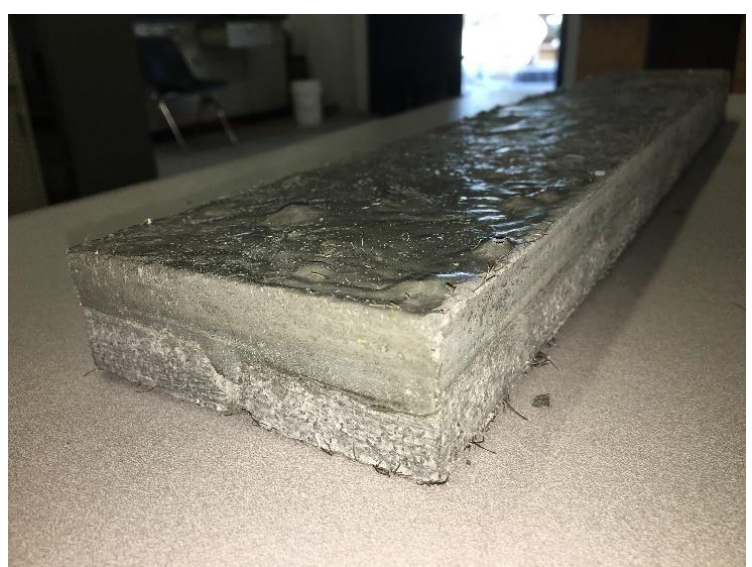

(a)

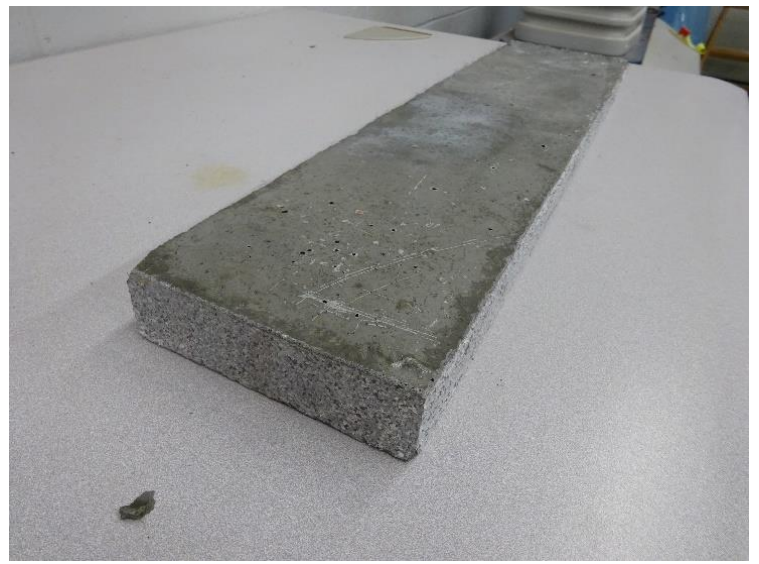

(c)

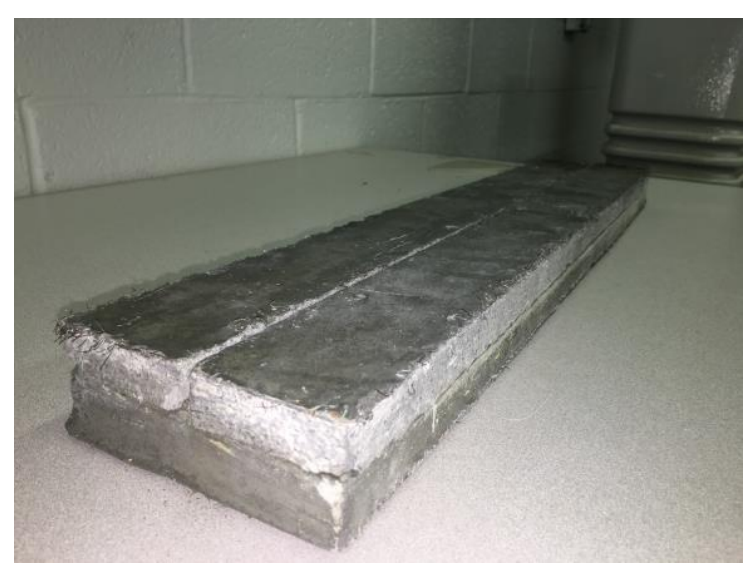

(b)

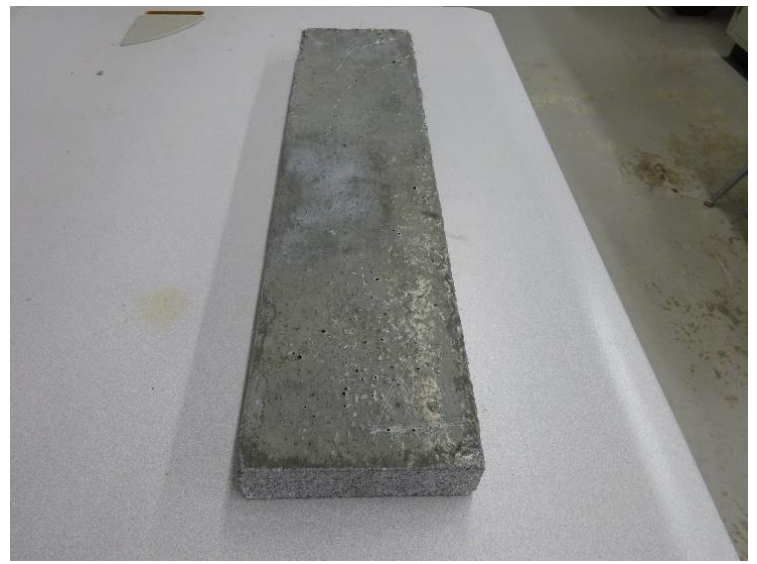

(d)

Figure 5-4 Simplified flange connection samples: (a) FC-P Specimen; (b) FC-N specimen; (c) SOLID-1 specimen; (d) SOLID-2 specimen 


\subsubsection{Experimental Work}

As it was confirmed through the experimental work discussed in the section of "Panel Action" in Chapter 2, there is no interaction between box-cell components along the panel's width and the adjacent panels. Based on this behavior, the flange connection should only resist the imposed moment forces along the length of roof deck. The ideal performance is that the composition of UHPC fill and depressed flanges act as a unit of solid cast altogether. In other words, it is ideal if depressed flanges and UHPC fill demonstrate same flexural strength as an identical monolithic solid section. In this regard, experimental tests were performed on simplified flange connection specimens to evaluate their bending capacity. The experimental investigation aimed at better understanding (1) the composite action of UHPC fill and depressed flanges together as a unit; and (2) validate the tongue-in-groove mechanism performance. Total of four specimens in two groups were prepared: Group 1 was included specimens demonstrating depressed flanges linked by UHPC fill using tongue-in-grooves mechanism, shown in Figures 5-2 (b), 5-3 and 5-4 (a and b); and Group 2, as the control samples, was included rectangular-solid-section specimens demonstrating a solid monolithic cast of UHPC fill and depressed flanges with an overall thickness of 1.5 in., see Figures 5-2 (c) and 5-4 (c and d). All cases were identical in width, overall thickness (1.5 in.) and testing length, as listed in Table 5-1. Both groups of specimens were tested for bending capacity. Group 1 was included two identical specimens, one aimed at positive bending test and one at negative, namely FC-P and FC$\mathrm{N}$ respectively. Positive test represents the system under normal operation due to the downward loadings; while the negative test represents the system under upward wind forces. Group 2 was included two identical specimens for statistical purpose, termed as 
Solid-1 and Solid-2. It was expected to obtain same capacity from both groups of specimens as the ideal result.

\subsubsection{Test Setup}

Samples were tested under three-point bending test illustrated in Figure 5-5. The tests measured the flexural strength and deflection. Universal testing machine served for the purpose. Machine was set to apply the load through a 2-inch-wide loading pad in a constant rate of crosshead speed of 0.05 inch per minute. Mid-span deflection was measured by crosshead movement indicator, automatically recorded by testing machine. The tests ended when samples dropped $80 \%$ of maximum load. Figures 5-6 through 5-8 show specimens under the testing load.

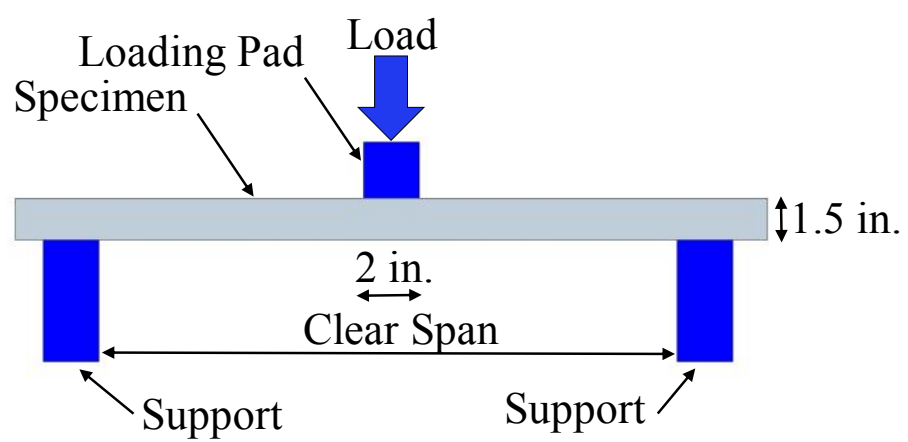

Figure 5-5 Test setup for flange connection 


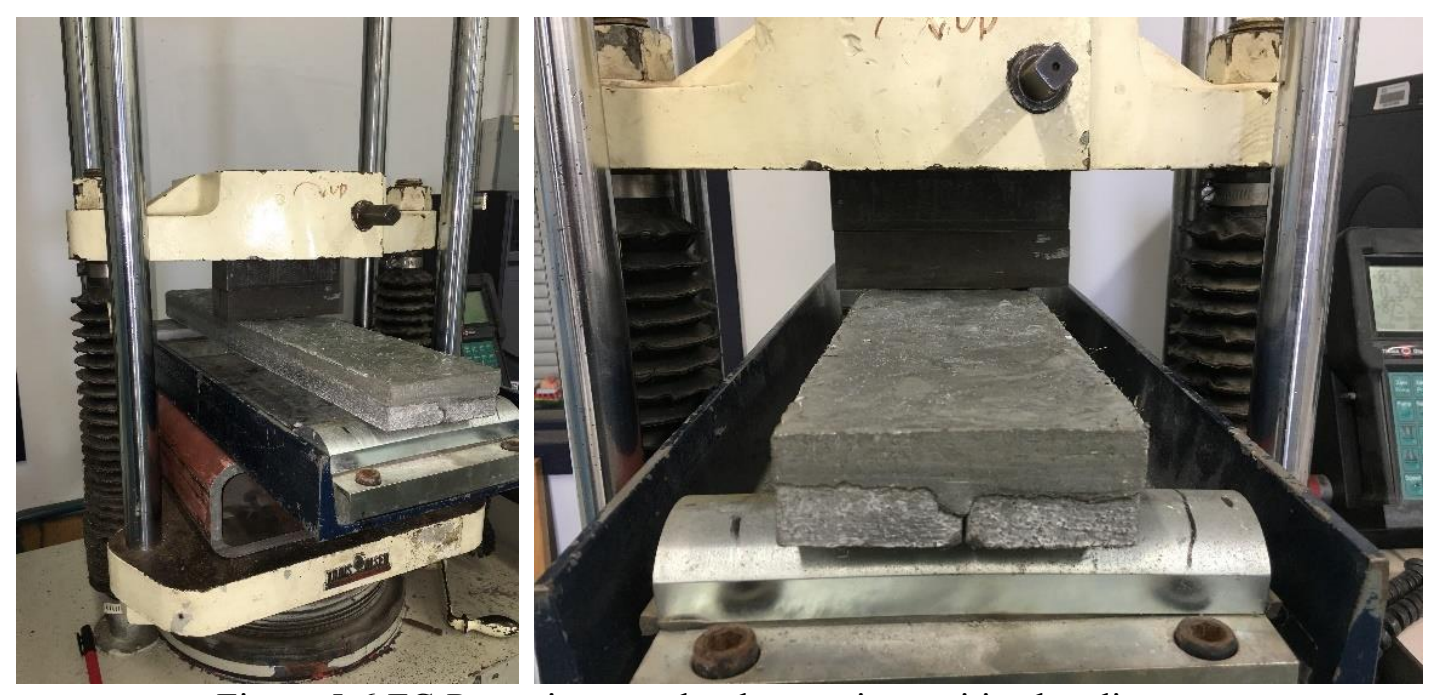

Figure 5-6 FC-P specimen under three-point positive bending test

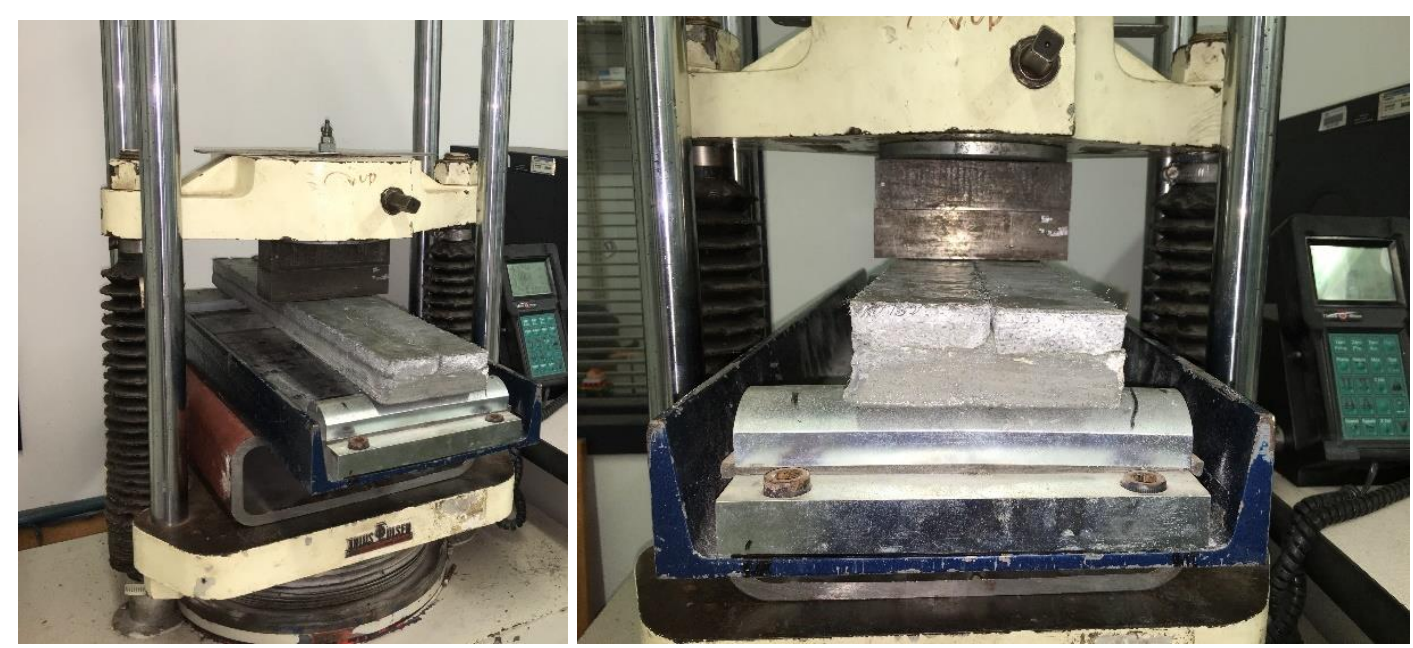

Figure 5-7 FC-N specimen under three-point negative bending test 

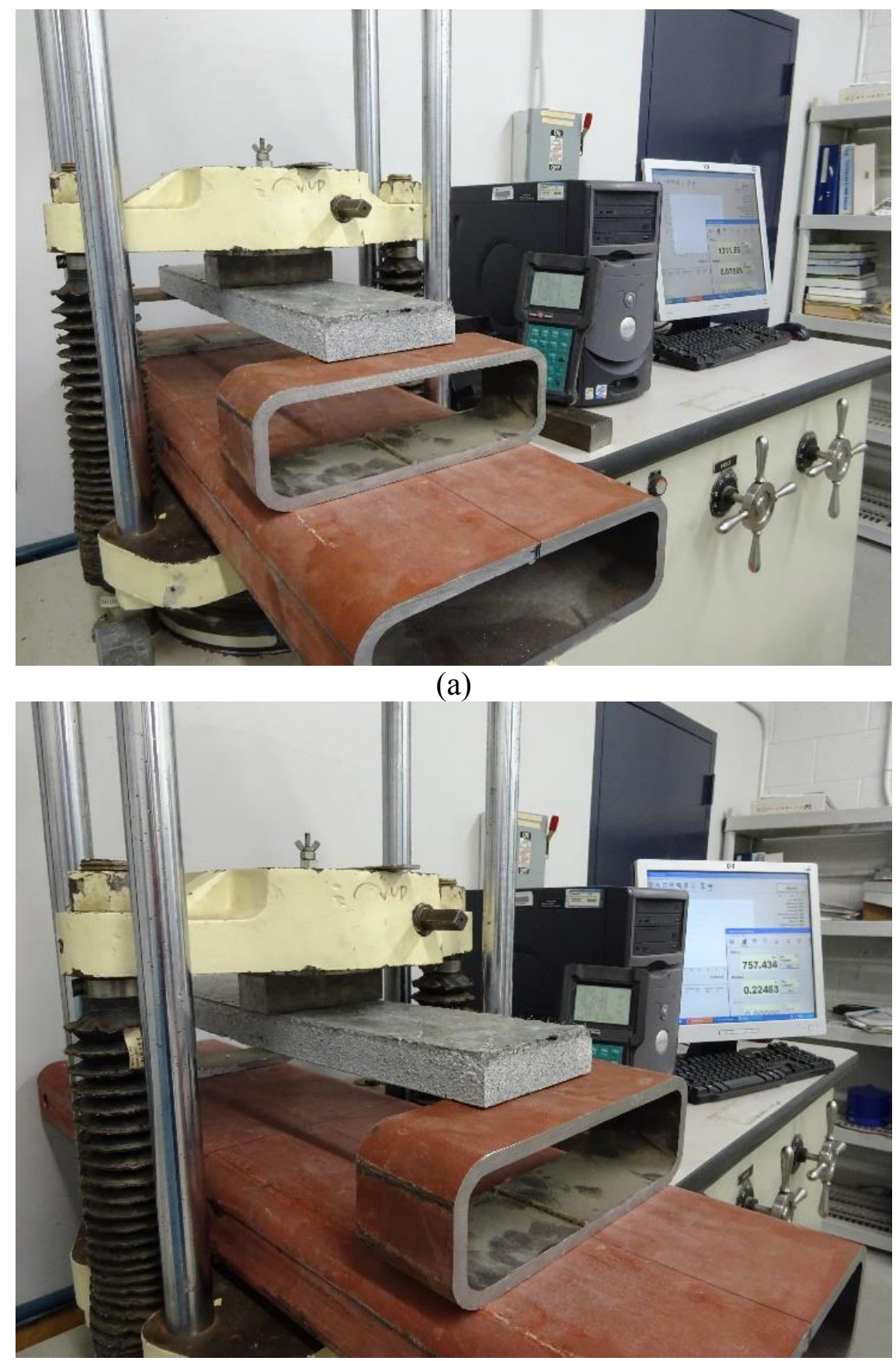

(b)

Figure 5-8 Group 2 specimen under three-point bending test: (a) SOLID-1 Specimen; (b) SOLID2 Specimen

\subsubsection{Test Results}

All four samples failed at flexural mode. The only crack was observed at mid-span at the convex side of specimens, as shown in Figure 5-9. The moment-deflection response 
of all four specimens are presented in Figure 5-10. As it was expected, both groups demonstrated almost same capacity. Test results are summarized in Table 5-1. FC-P and FC-N specimens exceeded expectation by $7.4 \%$ and $3.7 \%$ (compared to the average value of Group 2 control specimens).

As given, the tongue-in-groove design performed very well and showed adequate bond and interlock between the pieces with no need of non-UHPC shear connectors (e.g. steel shear stud). No sliding was observed at interaction surface. Experimental work confirmed that flange connection performs as good as the same thickness monolithic cast. In other words, connected panels using flange connection have the identical strength and performance as the solid monolithic cast of a panel with equal overall width. Flange connection provides link between the panels and allows full continuity of the top flanges across the roof. For future, full-scale specimens might be tested for overall validation.

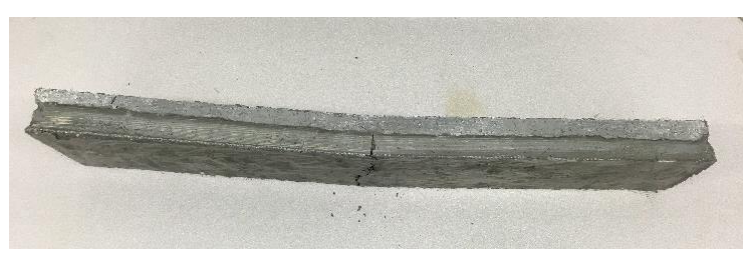

(a)

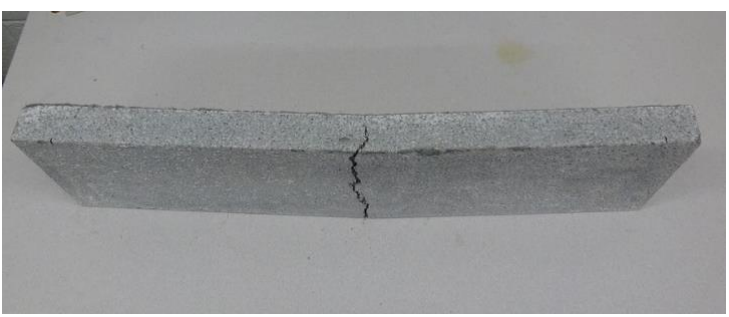

(c)

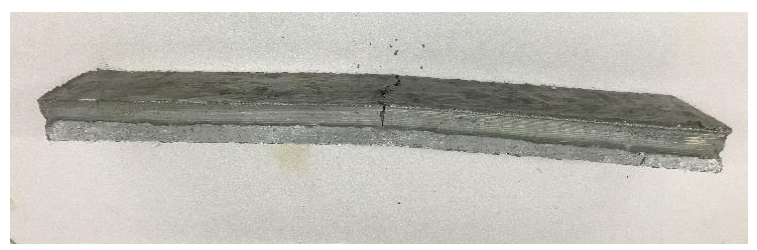

(b)

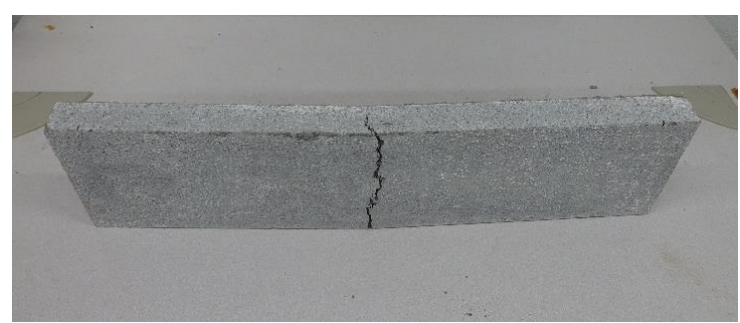

(d)

Figure 5-9 Failure mode of flange connection samples: (a) FC-P specimen; (b) FC-N specimen;

(c) SOLID-1 specimen; (d) SOLID-2 specimen 
Table 5-1 The Geometric Details of Flange Connection Specimens and Summary of Test Results

\begin{tabular}{lcccc}
\hline & \multicolumn{2}{c}{ Group 1 } & \multicolumn{2}{c}{ Group 2 } \\
\hline Specimen & SOLID-1 & SOLID-2 & FC-P & FC-N \\
Span Length (in) & 21 & 21 & 21 & 21 \\
Width (in.) & 4.5 & 4.5 & 4.5 & 4.5 \\
Overall Thickness (in.) & 1.5 & 1.5 & 1.5 & 1.5 \\
Compressive Strength f', (ksi) & 19.8 & 19.8 & 19.8 & 19.8 \\
Maximum Applied Load (kips) & 1.34 & 1.28 & 1.03 & 1.44 \\
Deformation at Maximum Load (in.) & 0.19 & 0.17 & 0.09 & 0.14 \\
Applied Moment (kip-ft.) & 0.58 & 0.56 & 0.45 & 0.63 \\
Average of Applied Moment (kip-ft.) & - & - & \multicolumn{2}{c}{0.54}
\end{tabular}

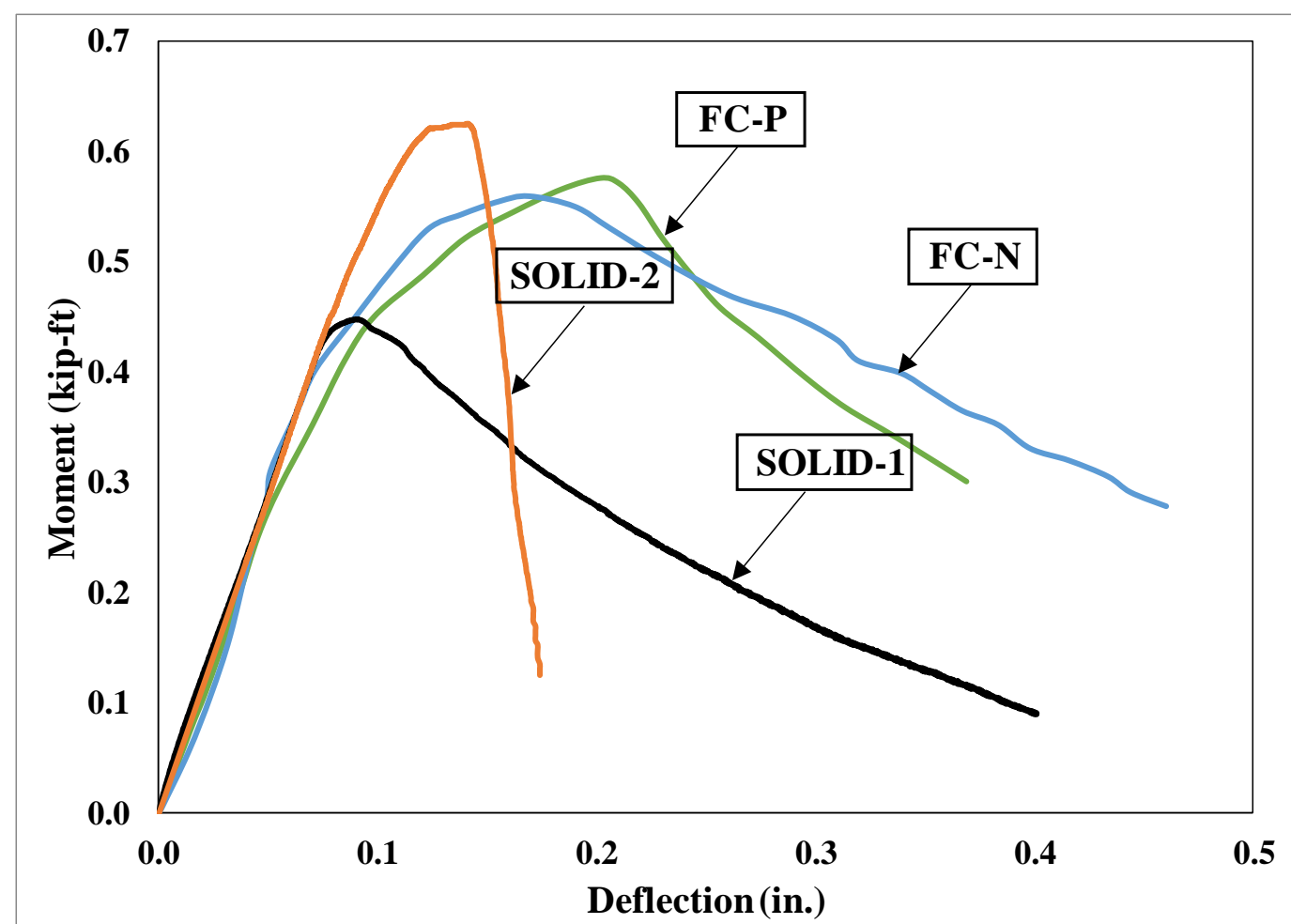

Figure 5-10 Moment-Deflection response of flange connections (panel-to-panel specimen connections)

\subsection{Roof-to-Wall Connection}

Roof-to-Wall connection is a type of connection that links the roof panels to the building structure. The discussed connection is proposed for future work. However, it is the designer's responsibility to design the appropriate connection as needed. 
Roof-to-wall connection is designed to be compatible with the most typical types of building structural systems such as: steel structures; reinforced concrete structures; and masonry buildings. As examples, Figure 5-11 illustrates the proposed connection for masonry buildings, reinforced concrete and steel structures. The same concept can be extended to other structural systems.

Roof-to-Wall connection is composed of three major components:

1) UHPC fill;

2) HSS reinforcements; and

3) Tensile studs or anchor bolts, depends on building structural system.

The extended HSS reinforcing bars at the end of panels transfer imposed loads from the roof deck to the UHPC fill by acting in shear, and then from there to the horizontal building structure (e.g. concrete beams, steel beams, concrete masonry unit (CMU) walls, tie-beams, and etc.) using: (1) tensile studs/anchor bolts; or (2) longitudinal HSS reinforcements continued and embedded in the masonry block, depends on the building structural system. This mechanism provides a continuous load path transmission.

Tensile studs can be pre-installed on the supporting structure using different methods depends on the type of building structural system:

1) either welded, punched or screwed to the steel structure; or

2) pre-cast anchor bolts into the CMU walls, concrete beams or tie-beams; or

3) continued longitudinal HSS reinforcement in masonry blocks.

Roof-to-wall connection not only provides continuity of load path from panels to the building structure, but also acts as a barrier and water intrusion prevention system. Given that the only consideration to constructing the connection is filling the joint by fresh 
UHPC after roof assembly, the simplicity of the process accelerates the on-site roof erection. In order to provide the form side for UHPC fill, panel's end can be blocked at the far end using two methods; (1) a 0.5-in.-thick layer of UHPC during the roof panels manufacturing process, which will act as embedded form and also an extra layer of water intrusion barrier additional to the UHPC fill; or (2) using pre-cut foam pieces, installed either on-site or off-site. Either practice works very well for the purpose. 


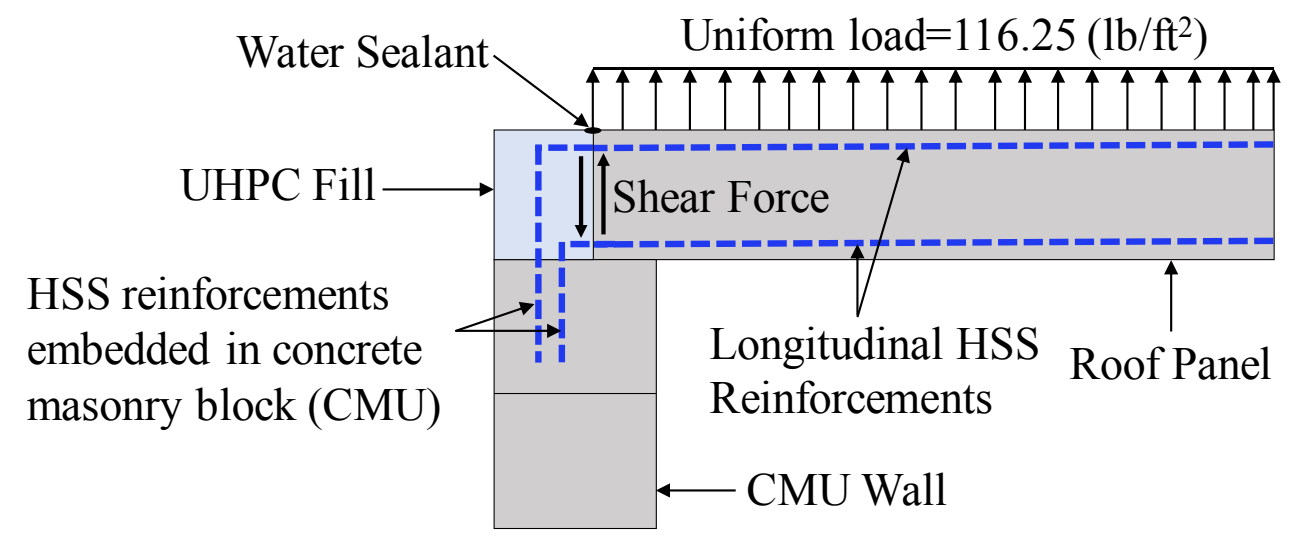

(a)

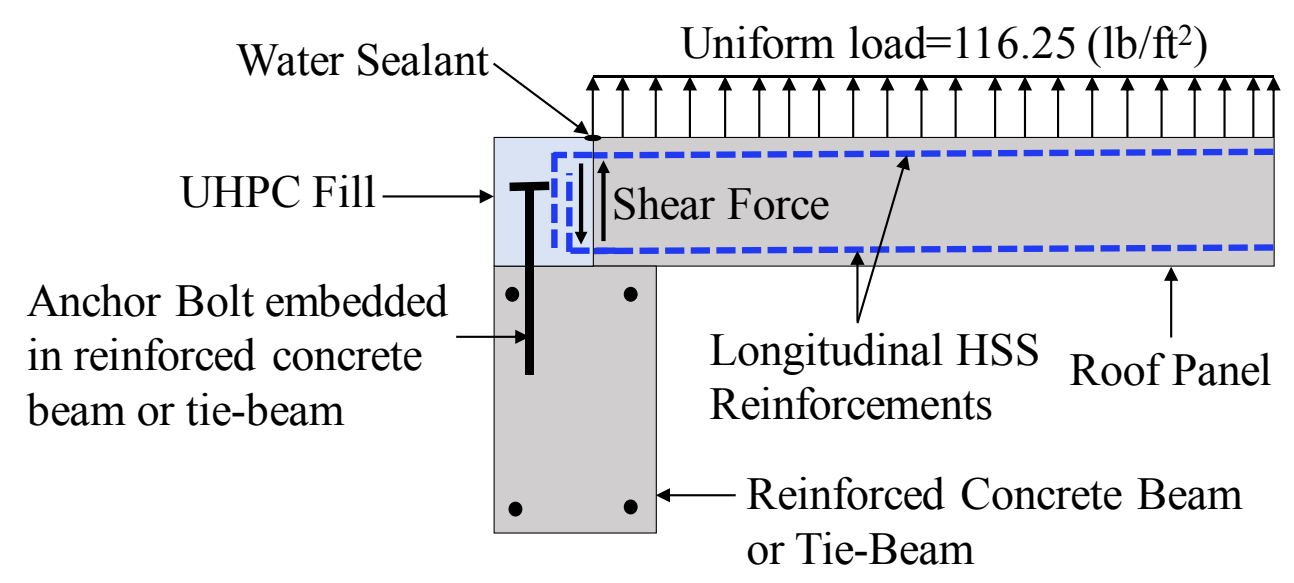

(b)

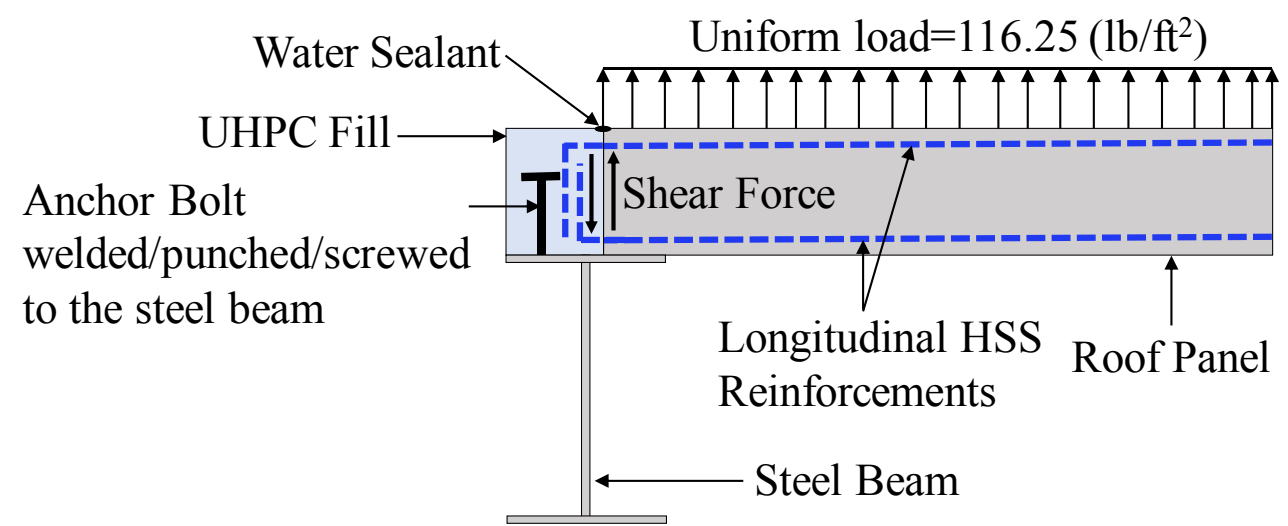

(c)

Figure 5-11 Roof-to-wall connection details to: (a) Masonry structure; (b) Reinforced concrete structure; (c) Steel structure 
Longitudinal HSS bars at the end of panels provide a shear force transmission mechanism from the roof deck to the UHPC fill, by providing interlock connectivity between the two parts. HSS bars withstand shear forces induced by wind uplift pressure. The total shear force applied can be estimated as:

$$
\mathrm{V}_{\mathrm{u}}=\mathrm{w} . \mathrm{A}_{\text {Roof }} / 2
$$

where, $V_{u}=$ Applied shear force per roof panel at the end support; $\mathrm{w}=$ Maximum upward design load from load combinations; $\mathrm{A}_{\mathrm{Roof}}=$ Roof panel footprint area.

In this study, applied shear is equal to $5.23 \mathrm{kip}$ at the support, by applying design uniform load of $116.25 \mathrm{lb} / \mathrm{ft}^{2}$, and footprint roof area of $20 \mathrm{ft}^{2}$ (20 ft. by $4.5 \mathrm{ft}$.) in the equation. This should be equal or less that the shear strength of HSS bars, which can be estimated as:

$$
\mathrm{V}_{\mathrm{n}}=0.6 \mathrm{f}_{\mathrm{y}} . \mathrm{A}_{\text {Steel }}
$$

Where, $V_{n}=$ total shear strength of longitudinal reinforcements; $f_{y}=$ Yield strength of reinforcing bars; and $\mathrm{A}_{\text {Steel }}=$ total area of reinforcing bars in a roof panel.

Using a yield strength of $100 \mathrm{ksi}$ for HSS reinforcing bars, and total area of reinforcing bars of $0.99 \mathrm{in}^{2}$ (the total of 9 number 3 reinforcing bars), the shear strength is calculated as $59.4 \mathrm{ksi}$, which is significantly higher than the required strength of $5.23 \mathrm{kip}$. Therefore, the existing HSS reinforcements offer shear strength considerably more than the required value.

The resultant forces in UHPC fill is transmitted into the horizontal supporting structure through the studs acting in tension. The magnitude of tensile force per stud or anchor bolt is equal to the shear force calculated using Equation 5-1 (5.23 kip) divided by 
number of tensile studs or anchor bolts. The tensile loading per studs (anchor) can be calculated as:

$$
\mathrm{T}_{\text {Stud }}=\mathrm{w} . \mathrm{A}_{\text {Roof }} / 2 \mathrm{~N}
$$

where, $\mathrm{T}_{\text {Stud }}=$ tension force per stud (anchor); $\mathrm{w}=$ Maximum design load from load combinations; $\mathrm{A}=$ Roof panel footprint area, $\mathrm{N}=$ number of studs (anchors) per roof panel width. Therefore, the required studs spacing depends on the desired quantity and size.

Future testing is anticipated to determine the strength of tensile studs. Given that the connection type has significant impact on the load bearing of the roof system -- which conservatively is considered as pinned-roller in this study -- the testing may also investigate the connection load bearing type (pinned or moment bearing). Once again, although the proposed connections, panel-to-panel and roof-to-wall, are deemed to be appropriate for most construction cases, different connections may be considered other than those presented in this study. 


\section{CHAPTER 6}

\section{SYSTEM ADVANTAGES}

\subsection{Introduction}

The proposed engineered roof system was originally designed to increase the wind resilience of buildings during high wind storm events, in particular hurricanes. Experimental tests and finite element analyses confirmed that the new roof structure performs as expected. Along the way of development, several significant improvements were obtained in addition to the hurricane resilient design, as followings:

1) weight;

2) overall depth;

3) span length;

4) reinforcement ratio; and

5) durability,

which all translate to the following significance:

(a) high structural efficiency;

(b) financial benefits;

(c) sustainability;

(d) safety; and

(e) demanding features, as are described next. 


\subsection{Structural Efficiency}

As addressed previously in Chapter 2, UHPC's high compressive and tensile strength enhanced with the high strength steel led to some structural improvements as followings: (1) weight; (2) overall depth; (3) span length; and (4) reinforcement ratio. Selfweight has significant impact on the long-span design. As span length increases, robust section is required, that consequently result into a heavier cross section. The high ratio of strength to self-weight of the proposed roof deck system makes it a light-weight wide-span low-profile system, beyond that is possible with current conventional reinforced concrete -- all possible with no shear reinforcements. As a comparative analysis, the same capacity conventionally reinforced concrete Lite-Deck floor system, a commercially available deck system -- with an overall depth of 12.25 in. (10.25 in. deck plus 2 in. foam form) and selfweight of $48.72 \mathrm{lb} / \mathrm{ft}^{2}$-- is offered for comparison. See Figure 6-1 for the new proposed roof section against Lit-Deck. The proposed system is almost three times lighter in weight, three times shallower in profile, and five times less reinforced (only longitudinal reinforcements), with no shear reinforcement or stirrups, as listed in Table 6-1 and shown in Figure 6-2. Moreover, experimental work demonstrated the 3/4 inch ultra-thin-walled section utilized successfully resist high imposed loads, the thinnest practical constructible structural thickness manufactured in practice using UHPC. 


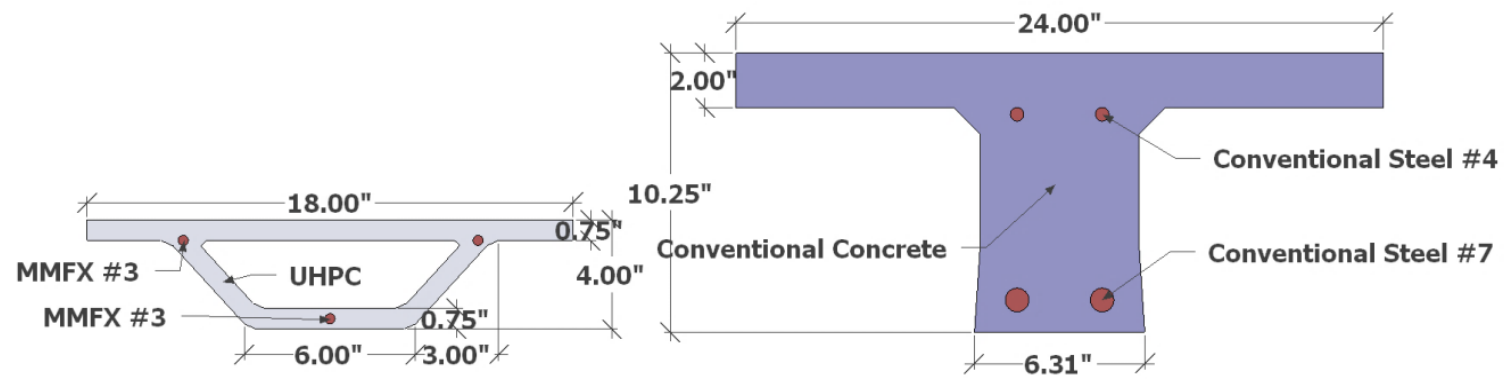

(a)

(b)

Figure 6-1 Cross section of the new roof system compared to Lite-Deck deck system

Table 6-1 The New Roof System Against Lite-Deck Deck System

\begin{tabular}{lcc}
\hline \multicolumn{1}{c}{ Item } & $\begin{array}{c}\text { New Roof } \\
\text { System }\end{array}$ & Lite-Deck \\
\hline Clear Span (ft.) & 20 & 20 \\
Weight (pound per square feet) & 17 & 48.72 \\
Overall section height (in.) & 4 & $10.25+2$ in. in-place form \\
Compressive strength of concrete (ksi) & $24^{\mathrm{a}}$ & $4^{\mathrm{b}}$ \\
Yield strength of reinforcement (ksi) & $100^{\mathrm{c}}$ & $60^{\mathrm{d}}$ \\
Longitudinal Reinforcement & $0.33 \mathrm{in}^{2}$ & $1.59 \mathrm{in}^{2}$ \\
Shear Reinforcement & $\mathrm{NO}$ & YES \\
Wind design & YES & \\
a Type: UHPC; & & \\
b Type: Conventional concrete; & & \\
c Type: High strength steel (HSS), Grade 100 & & \\
d Trne. Conventional steel Frade 60 & &
\end{tabular}

Steel Reinforcement (in²)

Overall section height (in.)

Weight (pound per square feet)

\section{Lite-Deck $=1.59 \mathrm{in}^{2}$}

New Roof $=0.33$ in $^{2} \mathbf{8 0 \%}$ Savings in steel consumption

\section{Lite-Deck $=12.25$ in}

New Roof $=4$ in $\quad 67 \%$ Savings in height

Lite-Deck $=48.72$ psf

New Roof $=17$ psf $65 \%$ Savings in concrete consumption

Figure 6-2 The new roof system improvement compared to Lite-Deck

\subsection{Material Cost}

In order to estimate the life cycle cost of the product, several items need to be factored in to the cost such as, initial cost, construction cost, maintenance, repair costs, post 
disaster costs, and insurance benefits. The material cost of the given design is compared with the cost estimate of two different types of conventional roofs: concrete roof and standing seam metal roof. Table 6-2 lists the material cost of the proposed roof system and conventional concrete roof. The material cost of the standing seam metal roofs is estimated to be $\$ 7.14$ per square foot on average (Homewyse.com).

The material cost of the proposed roof system is anticipated to be competitive. It would be more so if labor, fabrication and installation cost, post disaster cost and insurance benefits are considered in total cost. Supplementary data can lend more insight into the system's total initial cost and life costs.

Table 6-2 Material Costs for the Proposed Roof System and Conventional Concrete Roof

\begin{tabular}{lcc}
\hline Item & New Roof System $\left(\mathbf{\$} / \mathbf{f t}^{\mathbf{2}}\right)$ & Conventional Concrete Roof $\mathbf{( \$ / \mathbf { f t } ^ { 2 } )}$ \\
\hline Concrete & 3.50 & 1.31 \\
Reinforcing Steel & 0.90 & 2.81 \\
Material Total & 4.40 & 4.12 \\
\hline
\end{tabular}

\subsection{Financial Benefits}

The total initial cost and life cost of the new roof system would be more noticeable if labor, fabrication and installation cost, post disaster cost and insurance benefits are considered in total cost.

No crew, material, or time is needed for cutting, bending and installation of reinforcing bars -- as shear reinforcements are eliminated and longitudinal reinforcement ratio is noticeably decreased. Formwork is eliminated as roof panels will be pre-fabricated in quality controlled manufacturing environment. Because of the light-weight, more roof panels can be delivered to the jobsites on each single delivery. Less man-hours will be needed for unloading and installation, and no shoring would be required for erection. All 
which will lower the cost of roof construction alone, as well as boost the construction schedule.

Cost savings would be even more noticeable on the total initial construction cost of building by considering the effect of the following features on the overall building system:

1) the 4-in. low-profile deck will require 8-in. shorten columns, and will decrease the overall height of building;

2) long-span increases columns spacing and consequently reduces the total quantity of columns; and

3) light-weight will result in significant low mass on the roof level that considerably decreases design loads on the building structural frame with subsequent reduced size of columns, beams and foundation.

All these improvements will subsequently lower the total construction cost of the building structure. In addition, wide spans and column spacing have high demand in the modern architectural designs of industrial and commercial buildings.

The cost savings on the building structure frame can be multiplied on multi-story buildings, by using the proposed system as roof and floor decks. The new system can also be used as floor decks, since the only design consideration is the absence of wind pressures. That possibly result in either a shallower profile, longer span, or less reinforcing ratio (especially by elimination of reinforcements in the top flange) by re-designing the system. The less mass on floor levels and 8-in. shorter columns on each story level results in a substantial low total weight and building height, conceivably enabling additional floors within the same municipal imposed height restriction, and much lightweight structural system. The benefits would be especially noticeable in areas prone to both wind and 
seismic effects (such as South Carolina), as the total weight of building has a great impact on the earthquake-induced forces. Therefore, using the lightweight proposed deck system (as roof and/or floor) in such regions would significantly improve the seismic design in addition to wind design. As a result, the low-profile, wide-span and light-weight features result in cost savings, considering not the roof alone but the total cost of building construction.

\subsection{Sustainability}

All the above mentioned features including the significant reduced concrete consumption (65\%, see Figure 6-2) and subsequent material savings on building structure frame, reduced reinforcing ratio, and shear reinforcement elimination, will lead to lower raw material consumption, which will result in saving natural resources such as steel and concrete. Moreover, as previously described, the improved shipping efficiency, because of the reduced transportation, would also reduce carbon dioxide emissions from product transport. Likewise, the reduced concrete and steel demand for manufacturing, also collaborate in creating less carbon dioxide from the portland cement and steel production. UHPC's superior low permeability (due to the very dense matrix of fine constituent components and low water/cement ratio), high resistance to freeze-thaw cycling, and HSS's high corrosion resistance result in a durable, long lasting, low-maintenance system, thereby lowering life cycle maintenance costs as well as making an environmentally sustainable system. 


\subsection{Energy Efficiency}

Energy efficiency is an important factor in any roof system. Thermal bridging and inconsistent performance of insulation are major issues with conventional roof systems. There are several factors that affect the effectiveness of the roof insulation. For example, it mostly depends on the system assembly. It is almost impossible to provide a continuous insulation layer in between the layers of multilayer roof systems, as roof components are attached mechanically and has to break the insulation which causes thermal bridging.

The presented system here is a monolithic system that can be insulated either by foam board or spray foam applied directly onto the underside of the roof to create a continuous insulation layer. The American Society of Heating, Refrigerating and AirConditioning Engineers (ASHRAE) recommends an R-Value of 20 ( $\left.\mathrm{ft}^{2} .{ }^{\circ} \mathrm{F} \cdot \mathrm{h} / \mathrm{BTU}\right)$. Although, typical residential and commercial construction may face challenges to achieve such a standard, the proposed system can meet the recommendation by an R-Value of 21 $\left(\mathrm{ft}^{2}{ }^{\circ} \mathrm{F} . \mathrm{h} / \mathrm{BTU}\right)$ using a 2.75 -in. layer of closed-cell spray foam on the beneath roof surface. Table 6-3 lists the materials and their R-Values.

Table 6-3 R-Value of the Proposed Roof System

\begin{tabular}{lc}
\hline \multicolumn{1}{c}{ Component } & R-Value $\left(\mathbf{f t}^{\mathbf{2}} \mathbf{.}^{\mathbf{0}} \mathbf{F} \cdot \mathbf{h}\right.$ / BTU) \\
\hline Inside Air Film & 0.92 \\
2.75" Closed-cell spray foam Insulation & 17.88 \\
UHPC & 1.06 \\
Membrane & 0.44 \\
Outside Air Film & 0.70 \\
Total & $\mathbf{2 1 . 0}$ \\
\hline
\end{tabular}

\subsection{Safety}

Furthermore, the high stiffness at service load and high ductility at ultimate capacity make the combination of UHPC and HSS the most efficient solution for flexural members. 
The high stiffness at the initial stage of loading limits service deflections, and provides users comfort at service load during normal operation; while, the high ductility at ultimate state provides in advanced warning prior failure with enough time for users to evacuate the building, which bring a higher level of safety and comfort to the building and users, and potentially lower insurance premiums due to the lower risk during operation and severe weather events.

\subsection{Additional Features}

Hollow channels are provided to accommodate utilities such as electrical, mechanical, and HVAC lines. This feature is highly in demand in commercial, industrial and multistory residential buildings. Utility lines or ducts can be pre-installed within the panels either in hollow channels or in-between the box-cells. Furthermore, the system has the potential to incorporate pre-attached photovoltaic membranes to generate solar energy, or pre-attached bases for solar panels. The bases can be precast within the member to resist wind loads and act as the supporting frame. The new system could also incorporate preattached insulation to meet higher energy ratings. The new system would be a high quality product due to the tight quality control offered by precast concrete facilities.

Overall, the proposed roof system is structurally efficient, safe, reasonably cost effective, and environmentally sustainable, which translate to saving natural and fiscal resources, applicable to new construction or replacement of existing roofs to mitigate the hurricane resilience of buildings during natural disasters. 


\section{CHAPTER 7}

\section{CONCLUSIONS}

\subsection{Summary}

A novel composite flat roof system is proposed to promote hurricane resilience of buildings. The system is designed to satisfy Florida Building Code requirements. The new system is not only structurally improved to resist extreme wind events such as hurricanes -- but it is also light-weight $\left(17 \mathrm{lb} / \mathrm{ft}^{2}\right)$, low-profile (4 in.), ultra-thin-walled (3/4 in.), durable, low maintenance, and environmentally sustainable. All these significant attributes were achieved through an innovative combination of two advanced materials: ultra-high performance concrete (UHPC) and high strength steel (HSS). As the case study, the new roof system is designed to withstand winds up to 209 miles per hour at the mean roof height of 50 feet. A comprehensive experimental program was conducted on laboratory specimens in two groups of specimens, termed as single-cell and multi-cell specimens. The ultimate limit state (ULS) was investigated through the experimental work on short-span laboratory specimens: while, service limit state (SLS) was investigated via Finite Element analyses on longer-span numerical models calibrated with experimental results. Finally, two types of connections were proposed: (1) panel-to-panel connection that connects the roof panels together; and (2) roof-to-wall connection that connects the roof panel to the building structure. Experimental specimens and numerical models -- finite element analyses -proved that the proposed system successfully met all the Florida Building Code requirements for a 20-foot long span. The building configuration and design loads determined in this study can accordingly be adjusted for any other topographical regions 
in accordance with the intended building code and desire span length and roof height. Overall, it is proved that the proposed roof system is structurally efficient, safe, reasonably cost effective, and environmentally sustainable, applicable to the new constructions or replacement of existing roofs to mitigate hurricane damage of buildings during extreme wind events. Additionally, this study demonstrated the scientific contribution and novelty to create new lightweight thin-walled structural elements using UHPC-HSS system. The concept utilized in this research can be expanded to the other structural elements to effectively promote their efficiency and performance to a higher level.

\subsection{Conclusions}

The followings are the major outcomes of this study:

1) Flexural specimens showed a ductile flexural behavior with HSS bars yielding at mid-span.

2) Despite lack of any shear reinforcement, no shear crack was observed in any flexural tests.

3) Multi-cell specimens showed an improved flexural performance in terms of both cracking and ductility over single-cell specimens, in part due to the presence of transverse ribs.

4) A strong panel action was noted in multi-cell specimens with a distribution factor of 0.33 .

5) The proposed section showed optimal performance, as evident from its similar capacity/demand ratio in positive and negative bending. 
6) Despite lack of any shear reinforcement, shear specimen demonstrated high shear capacity for the proposed thin-walled box-cell section with a demand/capacity ratio of 1.7 .

7) Due primarily to the steel fiber pullout mechanism of UHPC, shear failure was not sudden or abrupt, but rather ductile.

8) This study confirmed that the UHPC-HSS system can be utilized for developing super light-weight low-profile ultra-thin-walled flexural members, even for wide-spans beyond that is possible to be achieved using the conventional reinforced concrete.

9) Experimental work confirmed the feasibility of the development and constructability of the ultra-thin-walled UHPC structural members as thin as $3 / 4$-inch. This is the thinnest structural thickness, which is practically possible.

10) UHPC demonstrated high shear resistant in the ultra-thin-walled section utilized, with no shear reinforcement or stirrup required, attributed to the UHPC high tensile strength.

11) Experimental work demonstrated that the UHPC-HSS system has high stiffness at the initial loading followed by a ductile behavior beyond, attributed to the steel fibers pullout mechanism of UHPC. This mechanical behavior provides the required stiffness at service load to fulfill the building codes serviceability requirements, while improving the safety of the system to a higher level by demonstrating adequate deformation warning at ultimate capacity. 
12) The one-way slab action was confirmed through the experimental program and FE numerical models. It was verified by both strain and deflection calculations.

13) Experimental specimens showed that the steel fibers content of UHPC mixture has tendency to segregate to the lower level of mold. This phenomenon increases the steel fibers volume fraction percentage of the lower level of the section, that consequently improves the tensile strength of the lower portion of the profile. Engineers and designers can take advantages of this tendency in formwork design and manufacturing practices to effectively promote the flexural capacity.

14) This study proved that the innovative material combination of UHPC and HSS offer high ratio of strength to the self-weight. Therefore, the UHPCHSS system lend itself as promising material for widening span purposes.

15) The proposed system is mainly aimed at roofs, however, it also can be used as floor decks by re-designing the system with no wind uplift pressure consideration, which potentially increases the span length and reduces the section depth.

16) The proposed system is almost three times lighter in self-weight $\left(17 \mathrm{lb} / \mathrm{ft}^{2}\right)$, three times shallower in profile (4 in. overall depth), and five times less in volume of reinforcement steel, with no shear reinforcement or stirrups required compared to conventional reinforced concrete. All these significant improvements will result in financial savings on total building construction cost, as make engineers and architects to be able to design 
smaller size of beams, columns and foundation thanks to the significantly less mass of story levels.

17) This study showed that the UHPC-HSS systems are environmentally friendly building materials, that make it feasible to reduce concrete consumption by $65 \%$ and reinforcement steel by $80 \%$, which make the UHPC-HSS system a sustainable design to save natural resources and reduce carbon footprint of a building.

\subsection{Future Research}

Building envelope is the first line of defense in natural disasters. The same concept utilized in this study -- using UHPC-HSS system -- can be implemented to create an innovative building envelope including both roof and walls. Therefore, future research is anticipated to develop a lightweight wall panel to protect buildings from natural disasters. Also, this study demonstrated that the proposed lightweight roof system can be used as

floor deck as well, which can significantly improve the multi-hazard design for wind and seismic due to its lightweight. Therefore, it would be a future work to test the proposed system under dynamic loads and evaluate the performance under multi-hazards. 


\section{REFERENCES}

ACI Committee. American Concrete Institute and International Organization for Standardization (2008). Building code requirements for structural concrete (ACI 318-08) and commentary.

AFGC (2002). "Ultra High Performance Fiber-Reinforced Concretes: Interim Recommendations." Scientific and Technical Committee, Association Française de Genie Civil.

Ahlborn TM, Peuse EJ, Misson DL. Ultra-High-Performance-Concrete for Michigan Bridges: Material Performance-Phase I. Rept. RC-1525. Michigan Department of Transportation. Lansing, MI 2008.

Ahmad, I., Suksawang, N., Sobhan, K., Corven, J., Sayyafi, E. A., Pant, S., \& Martinez, F. (2015). Develop Epoxy Grout Pourback Guidance and Test Methods to Eliminate Thermal/Shrinkage Cracking at Post-Tensioning Anchorages: Phase II. Transport Research International Documentation (TRID), Florida Department of Transportation.

Amir-Sayyafi, A., Mirmiran, A., Chowdhury, A. G. (2016). A Super Lightweight Hurricane-Resistant Thin-Walled Box-Cell Roofing System. Fundamental Research in Structural Engineering: Retrospective and Prospective: Proceedings of The Fourteenth International Symposium on Structural Engineering, 12-15 October 2016, Beijing, P.R. China, 698-704.

ASCE (2013). Minimum Design Loads for Buildings and Other Structures. Washington, DC, ASCE/SEI 7-10.

Ayscue, J. K. (1996). Hurricane damage to residential structures: risk and mitigation. National Hazards Research and Applications Information Center, Institute of Behavioral Science, University of Colorado.

Banks, D., Meroney, R. N., Sarkar, P. P., Zhao, Z., \& Wu, F. (2000). Flow visualization of conical vortices on flat roofs with simultaneous surface pressure measurement. Journal of Wind Engineering and Industrial Aerodynamics, 84(1), 65-85.

Baqersad, M., Sayyafi, E. A., \& Bak, H. M. (2017). State of the Art: Mechanical Properties of Ultra-High Performance Concrete. Civil Engineering Journal, 3(3), 190-198.

Crossett K, Ache B, Pacheco P, Haber K. (2013). National coastal population report, population trends from 1970 to 2020. National Oceanic and Atmospheric Administration, Department of Commerce, developed in partnership with the US Census Bureau. Retrieved in pdf from: http://oceanservice.noaa.gov/facts/coastal-population-report.pdf, last Accessed on. 2016 Oct; 7. 
FBC (2010). Florida Building Code. Country Club Hills, IL, International Code Council, Inc.

Ghasemi, S., A. Mirmiran, Y. Xiao and K. Mackie (2015). "Novel UHPC-CFRP Waffle Deck Panel System for Accelerated Bridge Construction." Journal of Composites for Construction 20(1): 04015042.

Ghasemi, S., P. Zohrevand, A. Mirmiran, Y. Xiao and K. Mackie (2016). "A super lightweight UHPC-HSS deck panel for movable bridges." Engineering Structures 113: 186-193.

Graybeal BA. (2005) "Characterization of the Behavior of Ultra-High Performance Concrete." PhD Dissertation. University of Maryland. College Park, MD.

Graybeal, B. A. (2006). Material property characterization of ultra-high performance concrete (No. FHWA-HRT-06-103).

Graybeal BA. (2007) "Compressive Behavior of Ultra-High-Performance FiberReinforced Concrete." ACI Materials Journal 2007; 104(2): 146-152.

Graybeal, B. A. (2014). "Tensile Mechanical Response of Ultra-High-Performance Concrete." Advances in Civil Engineering Materials 4(2): 62-74.

Graybeal, B., \& Davis, M. (2008). Cylinder or cube: Strength Testing of 80 to $200 \mathrm{MPa}$ (11.6 to 29 ksi) Ultra-High-Performance Fiber-Reinforced Concrete. ACI Materials Journal, 105(6), 603-609.

Habel, K., E. Denarié and E. Brühwiler (2007). "Experimental investigation of composite ultra-high-performance fiber-reinforced concrete and conventional concrete members." ACI Structural Journal 104(1): 93.

Habel, K., Viviani, M., Denarié, E., \& Brühwiler, E. (2006). Development of the mechanical properties of an ultra-high performance fiber reinforced concrete (UHPFRC). Cement and Concrete Research, 36(7), 1362-1370.

Harris, D. K. and C. L. Roberts-Wollmann (2005). Characterization of the punching shear capacity of thin ultra-high performance concrete slabs. Charlottesville, VA 22903, Virginia Department of Transportation.

Kahl, S. (2007). Corrosion Resistant Alloy Steel (MMFX) Reinforcing Bar in Bridge Decks (Vol. 1499). Michigan Department of Transportation. Lansing, MI

Keierleber, B., Phares, B., Bierwagen, D., Couture, I., \& Fanous, F. (2007, August). Design of Buchanan County, Iowa, bridge using ultra high performance concrete and PI girders. In Proceedings of the 2007 Mid-Continent Transportation Research Symposium. 
Kind, R. J., \& Wardlaw, R. L. (1979). Model studies of the wind resistance of two looselaid roof-insulation systems. National Aeronautical Establishment.

Knabb, R. D., Rhome, J. R., \& Brown, D. P. (2006). Tropical Cyclone Report: Hurricane Katrina, August 23-30, 2005. Fire Engineering, 159(5), 32-40.

Mintz, B., Mirmiran, A., Suksawang, N., \& Gan Chowdhury, A. (2016). Full-Scale Testing of a Precast Concrete Supertile Roofing System for Hurricane Damage Mitigation. Journal of Architectural Engineering, 22(3), B4016002.

Mintz, B., A. G. Chowdhury, A. Mirmiran, N. Suksawang and R. Kargarmoakhar (2015). "Design, Development, and Testing of a Composite Roofing System." Journal of Composites for Construction: 04015052.

Munich Re, N. (2014). Loss events worldwide 1980 - 2013. Retrieved in pdf from: https://www.munichre.com/site/corporate/get/documents E-

567437233/mr/assetpool.shared/Documents/5 Touch/_NatCatService/SignificantNatural-Catastrophes/2014/10-costliest-events-ordered-by-overall-losses.pdf, last Accessed on. 2016 Oct:7.

NOAA National Centers for Environmental Information (NCEI) (2016). U.S. BillionDollar Weather and Climate Disasters, Retrieved in webpage from: https://www.ncdc.noaa.gov/billions/, last Accessed on. 2016 Oct:7.

NOAA Hurricane Research Division (2016). Continental United States Hurricane Impacts/Landfalls 1851-2015. National Oceanic and Atmospheric Administration. Retrieved in webpage from: http://www.aoml.noaa.gov/hrd/tcfaq/E23.html, last Accessed on. 2016 Oct:7.

Perry, V. H., \& Seibert, P. J. (2008). The use of UHPFRC (Ductal $\left.{ }^{\circledR}\right)$ for bridges in North America: The technology, applications and challenges facing commercialization. In Proceedings of Second International Symposium on Ultra High Performance Concrete, University of Kassel, Germany (pp. 815-822).

Perry, V. H. (2003). A Revolutionary New Material for New Solutions. Technical Forum Presentation, Lafarge North America.

Pielke Jr, R. A., Gratz, J., Landsea, C. W., Collins, D., Saunders, M. A., \& Musulin, R. (2008). Normalized hurricane damage in the United States: 1900-2005. Natural Hazards Review, 9(1), 29-42.

Richard, P., \& Cheyrezy, M. (1995). Composition of reactive powder concretes. Cement and concrete research, 25(7), 1501-1511.

RICOWI (2007). "HURRICANE KATRINA INVESTIGATION REPORT " Roofing Industry Committee on Weather Issues, Inc. 
Saleem, M. A., A. Mirmiran, J. Xia and K. Mackie (2011). "Ultra-high-performance concrete bridge deck reinforced with high-strength steel." ACI Structural Journal 108(5): 601.

Sayyafi, E. A., Gan Chowdhury, A., \& Mirmiran, A. (2017). An Innovative HurricaneResistant UHPC Roof System. Journal of Architectural Engineering, in Press.

Sayyafi, E. A. (2016). Innovative Hurricane-Resistant Roof System. in Graduate Student Appreciation Week, Florida International University, p.g. 57

Simiu, E. and Scanlan, R.H. (1996), Wind effects on structures, third edition, John Wiley $\&$ Sons, Inc.

Sparks, P. R., Schiff, S. D., \& Reinhold, T. A. (1994). Wind damage to envelopes of houses and consequent insurance losses. Journal of Wind Engineering and Industrial Aerodynamics, 53(1), 145-155.

Wu, F., Sarkar, P. P., Mehta, K. C., \& Zhao, Z. (2001). Influence of incident wind turbulence on pressure fluctuations near flat-roof corners. Journal of wind engineering and industrial aerodynamics, 89(5), 403-420.

Xia, J., K. R. Mackie, M. A. Saleem and A. Mirmiran (2011). "Shear failure analysis on ultra-high performance concrete beams reinforced with high strength steel." Engineering Structures 33(12): 3597-3609. 
VITA

\section{EHSSAN AMIR SAYYAFI}

1999-2001

Associate of Science in Civil Engineering

Tehran, Iran

2002-2005

Bachelors of Science in Civil Engineering Azad University

Zanjan, Iran

2009-2012

Structural Engineer

Arces Mabna Ltd.

Tehran, Iran

2006-2010

Masters of Science in Civil Engineering Shomal University

Amol, Iran

2012-2016

Graduate Teaching/Research Assistant

Florida International University

Miami, FL

2012-2017

Doctor of Philosophy in Civil Engineering

Florida International University

Miami, FL

Sayyafi, Ehssan A., Amir Mirmiran, and Arindam Gan Chowdhury (2015). Development of a New Lightweight-wind-resistant Composite Roof System. International Concrete Sustainability Conference (ICSC), Miami, FL, May 11-13 2015,

Ahmad, I., Suksawang, N., Sobhan, K., Corven, J., Sayyafi, E. A., Pant, S., \& Martinez, F. (2015). Develop Epoxy Grout Pourback Guidance and Test Methods to Eliminate Thermal/Shrinkage Cracking at Post-Tensioning Anchorages: Phase II. Transport Research International Documentation (TRID), Florida Department of Transportation. 
Sayyafi, Ehssan A., Amir Mirmiran, and Arindam Gan Chowdhury (2016). Development of a Wind-Resistant Roof System. Federal Alliance for Safe Homes (FLASH) Annual Conference, Orlando, FL, January 27-29 2016,

Amir-Sayyafi, A., Mirmiran, A., Chowdhury, A. G. (2016). A Super Lightweight Hurricane-Resistant Thin-Walled Box-Cell Roofing System. Fundamental Research in Structural Engineering: Retrospective and Prospective: Proceedings of The Fourteenth International Symposium on Structural Engineering, 12-15 October 2016, Beijing, P.R. China, 698-704.

Baqersad, M., Sayyafi, E. A., \& Bak, H. M. (2017). State of the Art: Mechanical Properties of Ultra-High Performance Concrete. Civil Engineering Journal, 3(3), 190-198.

Sayyafi, E. A., Gan Chowdhury, A., \& Mirmiran, A. (2017). An Innovative Hurricane-Resistant UHPC Roof System. Journal of Architectural Engineering, in Press.

Sayyafi, E. A., Mirmiran, A., \& Gan Chowdhury, A. (2017). Development of a Lightweight Hurricane-Resistant Roof System. Under Preparation For submittal in ASCE Journal of Structural Engineering. 